\title{
Ervaringen vanuit de praktijk van professionele
}

leergemeenschappen (PLG's) ${ }^{1}$

Achtergronden, ervaringen en tips

Samenstelling en redactie:

Frank de Jong \& Ton van Wijck

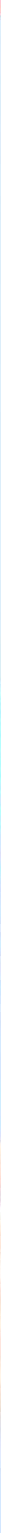




\section{Ervaringen vanuit de praktijk}

van professionele leergemeenschappen (PLG's) ${ }^{1}$ Achtergronden, ervaringen en tips

Samenstelling en redactie:

Frank de Jong \& Ton van Wijck 
"Met moeite scheur ik me los uit de hectiek van mijn werk. Als dat gelukt is, is het een

verademing om me samen met anderen te verdiepen in e-leren. Dat gun ik iedere collega."

"Als PLG-facilitator merk ik dat het constructief is zelf een PLG te hebben."

\section{Colofon}

$\begin{array}{ll}\text { Auteurs } & \text { Frank de Jong \& Ton van Wijck } \\ \text { Uitgever } & \text { Aeres Hogeschool Wageningen } \\ \text { Vormgeving } & \text { GAW ontwerp + communicatie, Wageningen } \\ \text { Eindredactie } & \text { Marlies Enklaar, Amsterdam } \\ \text { Foto's } & \text { Foto's IStock, Frank de Jong, AHW } \\ \text { Druk: } & \text { Opmeer De Bink Tenders (OBT), Den Haag. } \\ \text { ISBN } & 9789078712466 \\ \text { DOI } & 10.46884 / 2020.3\end{array}$

(c) Copyright Frank de Jong \& Ton van Wijck / Aeres Hogeschool Wageningen, 2020 All rights reserved. No part of this publication may be reproduced, stored in a retrieval system, or transmitted in any form or by any means, electronic, mechanical, photocopying, recording or otherwise, without prior permission of the publisher.

\section{Inhoud}

Voorwoord

Hoofdstuk 1

Inleiding: een Professionele Leergemeenschap

Ton van Wijck en Frank de Jong ${ }^{2}$, Aeres Hogeschool Wageningen (AHW)

Hoofdstuk 2

Professionele ruimte in de context van professionele leergemeenschappen: een

situationeel perspectief op leren

Harmen Schaap, Radboud Docenten Academie, Universiteit Nijmegen

Hoofdstuk 3

PLG-ervaringen vanuit het perspectief van management, deelnemers en facilitator

PLG 'Kwalitatieve verbetering van het onderwijs': ervaringen vanuit drie perspectieven Janny Rijks, Rianne Visser en Laura van Esveld, Mavo-schoolteam-PLG

Wilbert Waggelink en Ellen Messing, Aeres Hogeschool Wageningen (AHW)

PLG 'Bouwen van een gezamenlijke visie op leren': ervaringen vanuit drie perspectieven

Ton Spierings en Malou Gerbrands, PLG MBO gezamenlijke opleidingsvisie

Frank de Jong, Marjolein Wallenaar en Jan Hoed, Aeres Hogeschool Wageningen (AHW)

PLG VMBO: management en onderwijsvernieuwing in het VMBO

Jan Hoed, Aeres Hogeschool Wageningen

PLG 'E-leren en e-didactiek': ervaringen vanuit twee perspectieven

Ria van Dinteren \& Jan Tiemen Reinders,

Aeres Hogeschool Wageningen \& AOC bovenlocatie-PLG

PLG VMBO: 'Leren voor duurzaamheid': ervaringen vanuit drie perspectieven

Annelies de Waal, Bovenlocatie-PLG leren voor duurzaamheid

Stan Frijters en Ellen Messing, Aeres Hogeschool Wageningen

Hoofdstuk 4

Autoverhalen tijdens de reis naar en van PLG-bijeenkomsten

Ton van Wijck, Aeres Hogeschool Wageningen

Hoofdstuk 5

Onderzoek naar PLG's:

pilots voor de ontwikkeling van professionele leergemeenschappen

Cindy Poortman, Universiteit Twente

Hoofdstuk 6

PLG voor AHW-facilitators

Frank de Jong, Aeres Hogeschool Wageningen

Hoofdstuk 7

Suggesties voor succesvolle PLG's op basis van ervaring

Frank de Jong, Aeres Hogeschool Wageningen

Nawoord 


\section{Voorwoord}

Als je je oriënteert op een nieuwe studie of mogelijkheden om je verder te ontwikkelen kom je waarschijnlijk zoiets tegen als een 'Professionele Leergemeenschap' (PLG). Zo'n 'leergemeenschap' lijkt heel praktijkgericht te zijn en het kan het over verschillende inhouden gaan, maar hoe zit het eigenlijk? Waarom zijn er zoveel hogescholen en universiteiten die meededen aan een PLG-pilot?

Als je samen met een groep collega's een PLG vormt, dan kan dat genieten zijn. Zo'n samenwerkingsverband of team heeft meerwaarde voor iedereen, voor ieder thema en onderwerp, hoe klein of groot ook. Na een jaar kun je op elke plek die jij wilt, samen met collega's, een eigen PLG opzetten. Wat je nodig hebt zijn ademruimte, aandacht en inbreng van andermans professionaliteit. Aeres Hogeschool kan voor de juiste facilitators zorgen.

\section{In dit boekje vind je:}

- Antwoorden op vragen over PLG's zoals: wat is een PLG, hoe faciliteer je een PLG, 'wat is in for me' en wat vraagt het van jou en het management? Wat kan het mij opleveren voor m'n werk met leerlingen, studenten en collega's?

- Ervaringsverhalen van personen die aan zo'n PLG hebben meegedaan.

- Nieuwe invalshoeken. Hoe leuk en leerzaam kan samenwerken in een PLG zijn bijvoorbeeld met veertien collega's afkomstig van zeven verschillende locaties?

- Praktische informatie van docenten en facilitators die hiermee de afgelopen jaren ervaring hebben opgedaan.

- Antwoorden op vragen als: 'Wat werkt wel en wat niet?' 'Wat heb je er als docent aan en wat als school en leidinggevende?

\section{Terugblik op het PLG-project}

Na vijf PLG-jaren blikken we terug, als facilitators van Aeres Hogeschool Wageningen, teamleiders, of deelnemers, in de spiegel van de projectjaren waarin diverse PLG's actief zijn geweest. We hebben samen veel gedaan én veel te bieden - als professionals in, vanuit en na onze PLG's. aan toekomstige deelnemers en facilitators.

\section{Hoe werkt zo'n PLG voor mij?}

Stel: je werkt al een tijd in het onderwijs. De contacten met de leerlingen/studenten zijn meestal goed, wat duidelijk een positief effect heeft. Je hebt over het algemeen plezier in je werk en in de contacten met collega's. De leiding is tevreden over de resultaten die je met de klassen/groepen behaalt. Dat is fijn en geeft je stabiliteit.Je hebt echter ook veel om je heen gezien dat redelijk gaat, maar toch beter kan, dus je blijft nieuwsgierig. Wat is nodig om die verbetering in gang te zetten en wat kun jij daarvoor gebruiken?

Alleen al het denken daarover kan je energie geven. Het delen van ervaringen met collegaprofessionals levert praktische en bruikbare inzichten op die vaak direct toepasbaar zijn. Ook er samen over filosoferen, geeft je energie en beter inzicht. Vragen die aan de orde kunnen komen zijn: Waar zit die leerkracht in mij en anderen? Hoe kunnen kennis, inzichten en ervaring op andere gebieden, zoals natuur, milieu, diversiteit, maatschappelijke en economische (on)gelijkheid, ons inspireren in ons eigen vakgebied?

En nu...? Je oriënteert je op een vervolgstudie, bijscholing, training of een cursus voor jezelf of voor een collega of medewerker. Je vindt in dit boekje vast wel iets wat je daarbij van nut kan zijn.

Veel leesplezier en wie weet tot in een PLG!

Frank de Jong en Ton van Wijck 


\section{Hoofdstuk 1}

\section{Inleiding: een Professionele Leergemeenschap}

Ton van Wijck en Frank de Jong² , Aeres Hogeschool Wageningen (AHW)

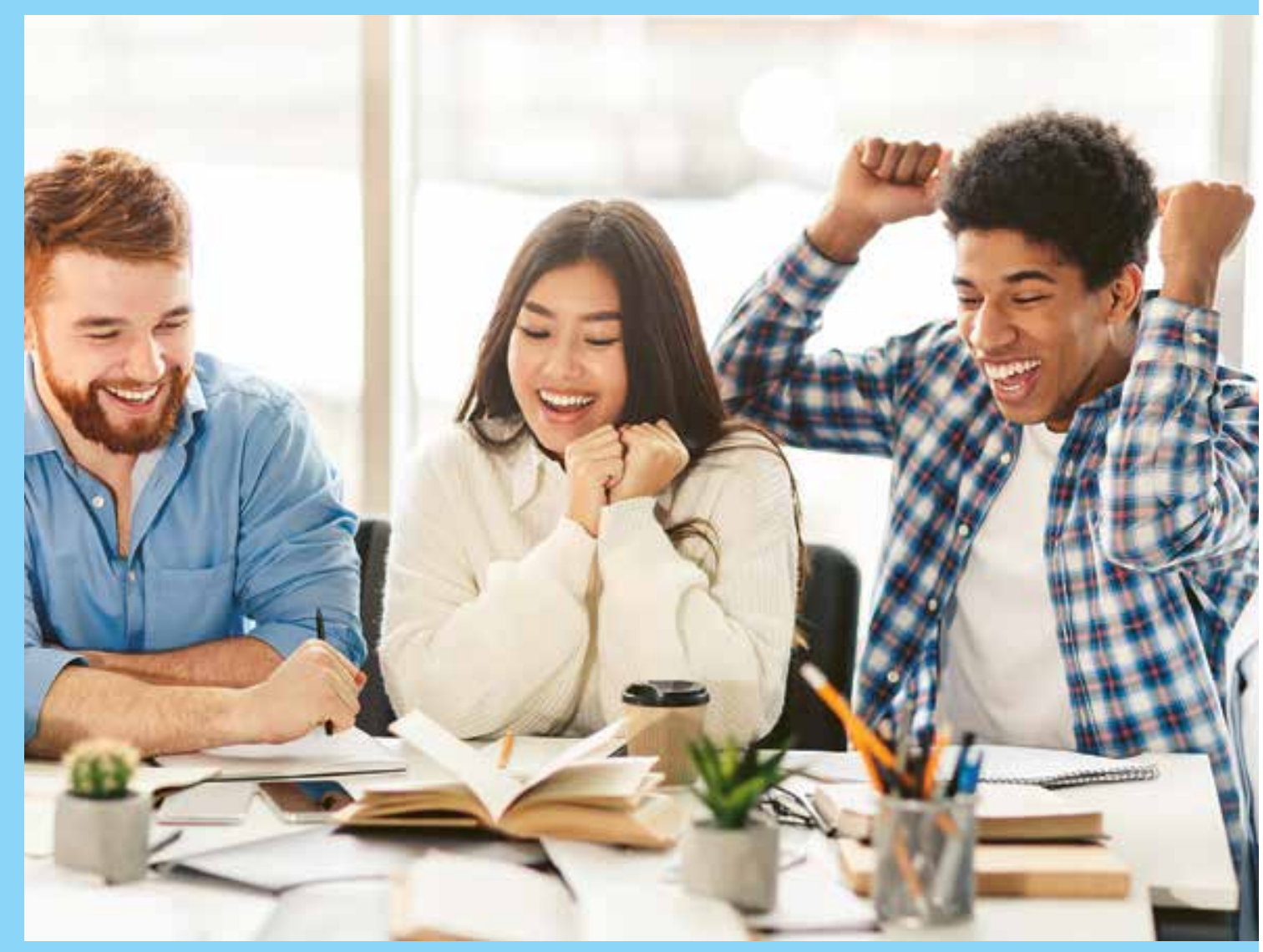

In PLG-bijeenkomsten ontmoeten collega's elkaar die zin hebben om zich samen te verdiepen in thema's in en rondom hun werk. Gedurende de vijf projectjaren waarin we actief zijn geweest in diverse PLG's hebben we daaromtrent veel ervaring opgedaan. Met veel plezier willen we je vertellen wat je mag verwachten van deelname aan een PLG en wat het positieve resultaat ervan kan zijn. De essentie van de PLG is:

Je leert samen (leer-gemeenschap) als professionals.

\section{Het thema waaraan gewerkt wordt vooraf bepaald}

Als voorbeeld noemen we twee actuele PLG-thema's die direct samenhangen met a) de situatie rondom het coronavirus en het geven van afstands- of hybride onderwijs en b) het huidige denken over dagelijks onderwijs en milieu:

1. Hoe kan e-learning en e-didactiek effectief ingezet worden in je werk met leerlingen/ studenten?

2. Hoe kan het curriculum van jouw vak uitgebreid worden met leren voor duurzame ontwikkeling?

Centraal in onze PLG's stond de vraag hoe je in het dagelijks werk aan de slag kunt gaan met het thema van en de resultaten die zijn voortgekomen uit de PLG. Er bestaan ook zeer effectieve PLG's die om specifieke vakgebieden, teamorganisatie of coachend leiderschap draaien.

\section{De werkvorm}

Je komt met collega's van verschillende scholen of locaties zo'n tien keer per jaar bij elkaar. Alle deelnemers geven hun wensen aan m.b.t. het thema. Er worden afspraken gemaakt over de werkwijze en jullie gaan samen aan de slag. Dat betekent dat je in een kleine (sub)groep iets ontwikkelt wat direct inzetbaar is in de dagelijkse onderwijspraktijk. Die nieuwe inzichten en ideeën presenteer je aan elkaar. Je vraagt om tips en aanvullingen, en die verwerk je.

Het ontwikkelde materiaal gebruik je in de daaropvolgende maand met één of meer groepen leerlingen/studenten en vervolgens verwerk je hun reacties. In de erop volgende PLG-bijeenkomst presenteer je de aangepaste versie van wat je aan het ontwikkelen bent, je licht toe hoe deze tot stand is gekomen en heeft uitgepakt. Collega's in de PLG geven daarop feedback, waarop verder wordt voortgeborduurd. Al het ontwikkelde materiaal en de ervaringen die tijdens de bijeenkomsten aan de orde zijn gekomen, zijn beschikbaar voor de deelnemers aan de PLG. Het is een samen voortbouwen op elkaars ervaringen en ideeën. Zo bouw je in korte tijd een heleboel kennis, ervaring en inzichten op omtrent een thema, de werkvorm van de PLG en de werkvormen met leerlingen/studenten.

Uiteraard doe je ook veel ervaring op over het geven van collegiale adviezen en opbouwende kritiek, en over het samen ontwikkelen van inzichten en visie op onderwijs en leren. Uit de praktijk blijkt dat PLG-ervaringen daarnaast goed zijn in te zetten voor andere samenwerkingsvormen, al dan niet op de eigen locatie.

\section{Leeswijzer}

Hoofdstuk 2 is een bijdrage van Harmen Schaap. Hij spreekt over PLG's als middel dat kan worden ingezet voor professionalisering van leraren en schoolontwikkeling. Dit doet Schaap door nader uit te leggen hoe PLG's in de praktijk werken of zich manifesteren, en wel op basis 


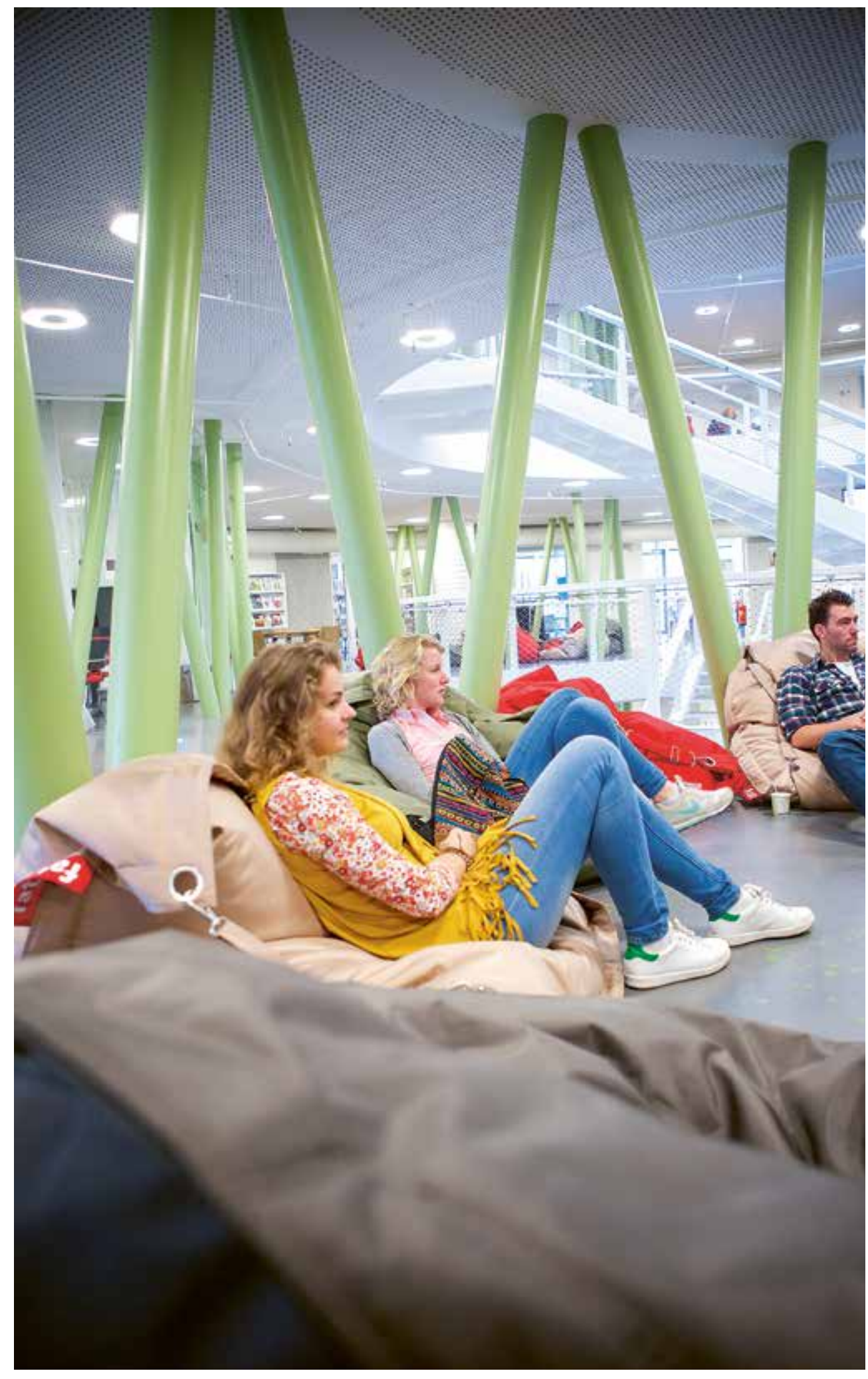

van de uitkomsten van drie recentelijk verschenen onderzoeken. Hij eindigt zijn betoog met een zestal vragen die als ontwerpprincipes kunnen fungeren bij de keuze voor en/of het op touw zetten van een PLG.

In hoofdstuk 3 zijn ervaringen te vinden van deelnemers aan vier verschillende PLG's, zowel afkomstig uit het management als facilitators. Elke casus eindigt met zaken die een positieve invloed hebben gehad op het functioneren en/of faciliteren van de betreffende PLG. Met dank aan Janny Rijks, Rianne Visser, Laura van Esveld, Wilbert Waggelink en Ellen Messing voor het delen van hun ervaringen in een mavo-schoolteam-PLG. Daarbij stelde elk teamlid een leervraag op, passend bij datgene wat in het primaire proces van belang is en aansluitend bij het teamplan. Ton Spierings, Malou Gerbrands, Frank de Jong, Marjolein Wallenaar en Jan Hoed deelden op hun beurt hun ervaringen met een mbo-opleidingsteam-PLG in het ontwikkelen van en concretiseren in de eigen onderwijspraktijk van een gezamenlijke opleidingsvisie.

Ria van Dinteren en Jan Tiemen Reinders lieten weten welke vormen van e-leren en e-didactiek, vanuit de praktijk van het onderwijs, zijn ontwikkeld in een bovenlocatie-PLG. Annelies de Waal, Stan Frijters en Ellen Messing ten slotte lieten weten wat ze geleerd hebben in een bovenlocatiePLG met betrekking tot de uitwerking en ontwikkeling van leren voor duurzaamheid.

De PLG komt vaak neer op 'samen uit en samen thuis'. Voor de meeste docenten die hebben deelgenomen aan PLG's was de autorit vaste prik - veelal met $z^{\prime} n$ tweeën, steeds vertrekkend vanaf dezelfde locatie. Dat leidde vooraf tot bespiegelingen en achteraf tot reflecties, tot steeds vertrouwder wordende gesprekken. Afspraken, hoop, niet lukken, afreageren, samen zien wat er wel kan en ook werkt... Een deel van die (auto)verhalen is in deze publicatie geanonimiseerd opgenomen op basis van aantekeningen over wat deelnemers elkaar vertelden tijdens PLG's. Daarin kun je van allerlei vinden over wat PLG's zo bijzonder en direct bruikbaar maakt. Je vindt ze in hoofdstuk 4

In hoofdstuk 5 bespreekt Cindy Poortman de effecten van onderling beïnvloedende factoren op basis van een, door het ministerie van OCW gefinancierd, landelijk onderzoek naar PLG's. Het ging om vijftien pilots van professionele leergemeenschappen (Ministerie van Onderwijs, Cultuur en Wetenschap, 2013).

Het faciliteren van een PLG is een kunst en een kunde. Dat mag blijken uit hoofdstuk 6, waarin facilitators van Aeres Hogeschool Wageningen (AHW) reflecteren op hun eigen bloed, zweet en tranen, ofwel de inspanningen, energie die ze gestoken hebben in het opzetten en ondersteunen van hun PLG om erachter te komen wat wel en niet werkt of hoe het anders kan.

In hoofdstuk 7 beschrijft Frank de Jong de vele mogelijkheden die in de praktijk blijken te werken en wat daarvoor nodig is op de locaties en in de schoolorganisatie.

\section{Referentie}

Ministerie van Onderwijs, Cultuur en Wetenschap (2013). Ontwikkeling van professionele leergemeenschappen Pilots professionele. Den Haag: OCW Publicatie-nr. 12439-1:

Ministerie van Onderwijs, Cultuur en Wetenschappen. Zie: https://www.delerarenagenda.n// documenten/publicaties/2015/04/07/brochure-professionele-leergemeenschappen 


\section{Professionele ruimte in de context van professionele leergemeenschappen: een situationeel perspectief op leren}

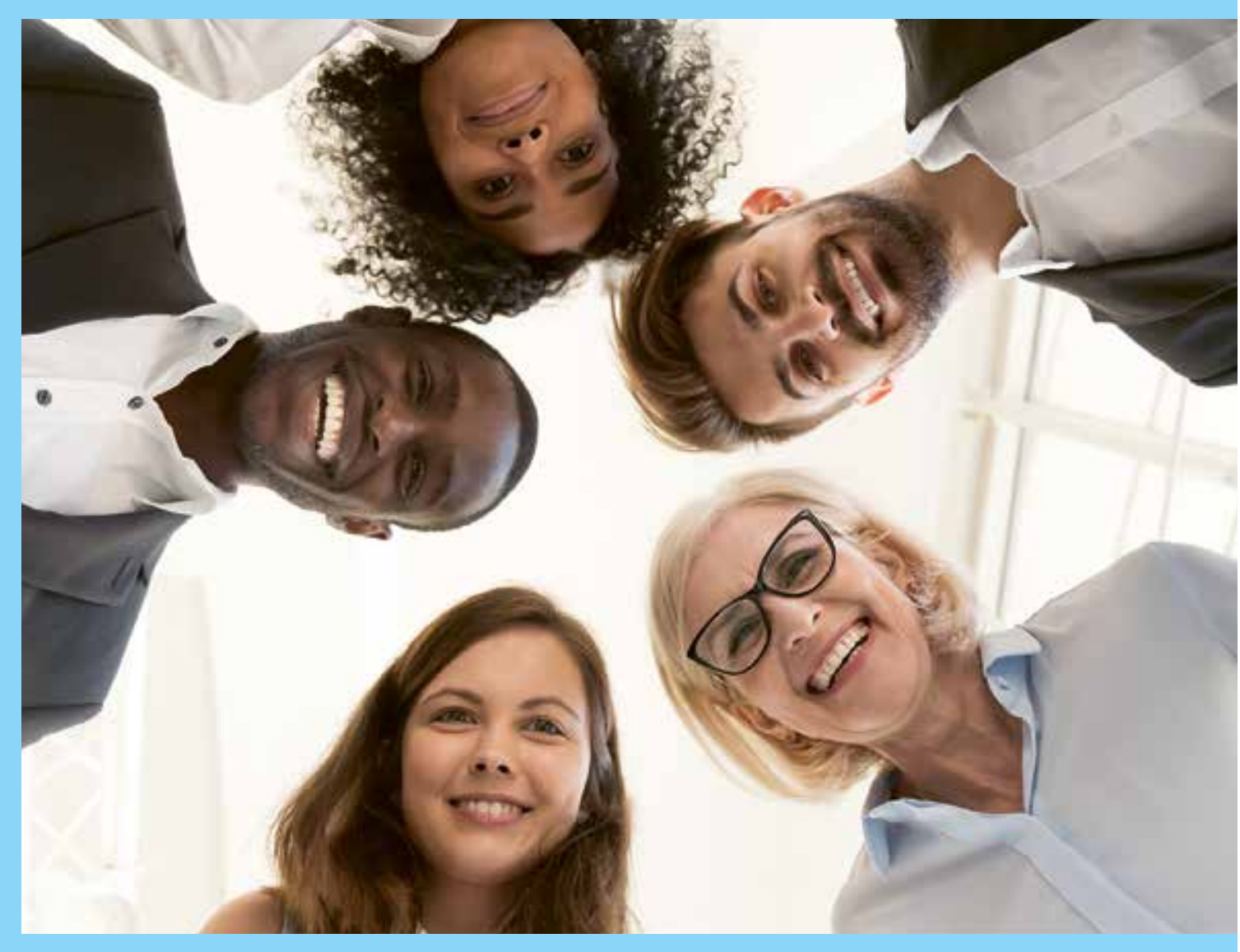

\section{Een casus}

Marieke, een lerares Nederlands met ongeveer zeven jaar werkervaring, neemt voor het eerst deel aan een professionele leergemeenschap (PLG). Deze PLG bestaat uit zestien leraren van verschillende scholen die allemaal 'iets' anders willen met het schoolvak Nederlands. De PLG wordt begeleid door een vakdidacticus Nederlands van een lerarenopleiding en een procesbegeleider.

De leidinggevende van Marieke heeft haar toestemming gegeven om één jaar te participeren in deze PLG. Hij denkt niet alleen dat zij er veel kan leren, maar ook dat de school er wat aan heeft. Ondanks de drukte op haar werk - ze is mentor van een $V_{5}$-klas en voor het eerst verantwoordelijk voor een eindexamenklas - is ze aan het begin van het schooljaar erg gemotiveerd om deel te nemen aan de PLG, omdat ze graag een betere leraar wil worden. Tevens vindt ze dat het vak Nederlands op haar school ook wel voor verbetering vatbaar is. Veel leerlingen vinden het saai, en dat vindt ze zelf eigenlijk ook.

Marieke ervaart de PLG waaraan ze gedurende het schooljaar deelneemt als een fijne plek waar ze niet alleen gelijkgestemden spreekt, maar ook input krijgt om haar ideeën over het schoolvak Nederlands nader uit te werken. Ze krijgt goede feedback en ook nieuwe theoretische input. Halverwege het schooljaar bespreekt ze de nieuwe ideeën in haar sectie. De opzet is dat ze, samen met haar collega's, een kort onderzoek doet onder haar leerlingen en op basis daarvan een voorstel schrijft voor een curriculumverandering, die het volgende schooljaar zal ingaan. Haar collega's en ook haar sectieleider reageren in de ogen van Marieke evenwel terughoudend op haar voorstel. Het kost haar bijvoorbeeld moeite om haar ideeën te bespreken in de sectie, en tijdens overleggen staan vaak praktische zaken centraal. Ook merkt Marieke dat een aantal van haar directe collega's niet direct zit te wachten op nieuwe ideeën. Immers, het onderwijs gaat toch goed en er zijn geen leerlingen of ouders die klagen, zo krijgt Marieke te horen.

Marieke merkt aan zichzelf dat haar motivatie om aan de PLG deel te nemen hierdoor afneemt, mede omdat de sectieleider niet meer zo enthousiast is als aan het begin van het schooljaar.

Wanneer ze dit met hem bespreekt, merkt ze dat er weinig ruimte is om inhoudelijk over andere of nieuwe vormen van onderwijs te praten. Haar sectieleider zegt bijvoorbeeld tijdens één van de laatste overleggen dat de eindresultaten van de school vorig jaar zijn achtergebleven en dat dit jaar extra geïnvesteerd zal worden in de lessen om de eindcijfers weer op peil te krijgen.

Daar passen volgens hem geen experimenten bij. Tegelijkertijd heeft Marieke haar handen vol aan zowel haar mentorklas als haar eindexamenleerlingen. Beide groepen beginnen steeds meer van haar pedagogische en vakinhoudelijke expertise te eisen, wat veel tijd en energie opslokt.

\section{Inleiding}

Het inzetten van professionele leergemeenschappen (PLG's) als middel voor professionalisering van leraren en schoolontwikkeling is de laatste decennia sterk toegenomen, zowel in Nederland als daarbuiten. Er worden niet alleen verschillende definities van PLG's gehanteerd, er bestaan ook verschillende vormen van. Datateams, docentontwikkelteams en (vakdidactische) netwerken hebben bijvoorbeeld allemaal tot doel ruimte te creëren om, via samenwerking tussen leraren, de professionele ontwikkeling van diezelfde leraren en schoolontwikkeling te 
bevorderen. Dit soort van PLG's zijn alle gestoeld op het idee van peer collaboration, hetgeen wil zeggen dat ervan wordt uitgegaan dat samenwerking tussen leraren tot duurzame professionaliteit leidt. Daarnaast worden ook bestaande vaksecties (zie bijv. Lomos et al. 2011) en scholen als lerende organisaties gezien als PLG's (Schenke, Sligte, Admiraal, Buisman, Emmelot, Meirink \& Smit 2015)

Het bovenstaande voorbeeld van Marieke illustreert dat het inzetten van PLG's als middel om de professionaliteit van leraren en schoolopleidingen naar een hoger niveau te brengen geen sinecure is. Marieke ervaart haar deelname aan de PLG ('een echte leeromgeving') aanvankelijk als positief, maar gaandeweg verandert dit, enerzijds onder invloed van haa volle agenda en anderzijds door het beperkte draagvlak dat ze hiervoor op haar school ervaart. Een interessant perspectief is dat van 'professionele ruimte: Marieke ervaart wel professionele ruimte in de PLG, maar in veel mindere mate vanuit haar school.

In dit hoofdstuk wil ik graag, via het perspectief van professionele ruimte, inzoomen op de wijze waarop PLG's in de praktijk functioneren en zich manifesteren. Eerst ga ik in op de uitkomsten van drie recentelijk verschenen onderzoeken, alvorens ik het hoofdstuk afsluit me een beschouwing op PLG's vanuit een situationeel perspectief op leren. Ik zal tevens een lijst met vragen presenteren die gebruikt kan worden als richtlijn/ bij het organiseren van PLG's. Voor deze doeleinden gebruik ik een brede beschrijving van professionele leergemeenschappen.

Elementen die de ontwikkeling van professionele leergemeenschappen beïnvloeden (Schaap \& De Bruijn 2018)

Het onderzoek van Schaap en De Bruin (2018) omvat een rapportage van een driejarige studie naar het functioneren van vier PLG's. Eén PLG was gepositioneerd in een lerarenopleiding, terwijl de andere drie PLG's werden geïnitieerd vanuit scholen voor voorbereidend middelbaar beroepsonderwijs (vmbo). De leraren/lerarenopleiders die de beoogde innovatie moesten ontwikkelen, waren leden van de PLG, met als primus inter pares een schoolprojectleider. Elke PLG werd ondersteund door de directie met faciliteiten en door de facilitators. De PLG's maakten een beschrijving van het vakmanschap van de vmbo-docent en van de professionaliseringsactiviteiten die deze ontplooiden om dit vakmanschap verder te ontwikkelen.

Door middel van participatief onderzoek is van elke professionele leergemeenschap een portret gemaakt. Deze portretten zijn geanalyseerd en met elkaar vergeleken. Uit de resultaten blijkt dat ten minste zeven factoren van grote invloed zijn op het functioneren van PLG's in scholen: 1) taakperceptie, 2) groepssamenstelling, 3) spanningen (tussen voornamelijk eigen leerbehoefte en de doelen van de PLG, en tussen de dynamiek in de PLG en de administratieve projectorganisatie van de PLG), 4) positionering van de PLG in de school, 5) leeractiviteiten, 6) verspreiden (wat we 'externaliseren' hebben genoemd) van ontwikkelde producten en inzichten van de PLG in de school en 7) eigenaarschap van individuele deelnemers aan de PLG over voornamelijk de inhoudelijke oriëntatie ervan. Deze zeven elementen zijn contextafhankelijk en temporeel van aard.

Zo bleek dat veranderingen in de samenstelling van een professionele leergemeenschap het functioneren zowel kan belemmeren als bevorderen, afhankelijk van de aard en oorzaak van de verandering (contextafhankelijk) of van het moment van de verandering (temporeel).
Daarnaast bleek dat een looptijd van drie jaar voor PLG's amper voldoende is om een bijdrage te kunnen leveren aan de ontwikkeling van een schoolsysteem. Deze tijdsfactor is een niet te onderschatten voorwaarde voor het functioneren van PLG's in scholen. Met andere woorden: voor de inrichting van PLG's moet er voor leraren voldoende tijd en professionele ruimte zijn om binnen de PLG en de schoolorganisatie onderwijs te ontwikkelen. De tijdsfactor lijkt een clichématig gegeven te zijn, maar onze resultaten laten zien dat de meeste PLG's zich binnen drie jaar intern hebben geprofileerd. Ook bleek dat een opstartjaar nodig is om bekend te raken met de opdracht en de taken, en om groepsvorming op gang te krijgen. Een directielid van één van de betrokken scholen zei hierover: "Zoeken is ook leren, maar het proces kost veel tijd, waardoor de inhoud wat op de achtergrond raakt." Mogelijk ligt hieraan onvoldoende tijd voor de professionele ontwikkeling van leraren ten grondslag, alsook voor externe profilering en zichtbaarheid van de PLG. Een andere leraar voegde daaraan toe: "Maar ik vind ook dat daar de gelegenheid en de ruimte niet voor is. En sowieso ook geen ruimte om buiten de kaders te denken. Want het gaat om eindexamens, om PTA's, om vaste programma's, en de uitwisseling is daardoor redelijk beperkt."

Door dit onderzoek kwam verder aan het licht deze zichtbaarheid ook kan bijdragen aan feedback- en reflectieprocessen binnen de school, die op hun beurt weer voeding kunnen geven aan de reflectieve dialoog in PLG's. De conclusie luidt dat leraren genoeg ruimte moeten krijgen voor de ontwikkeling van eigenaarschap met betrekking tot vooral de inhoudelijke kant van de PLG. Kwesties die de deelnemers bijvoorbeeld bezighouden, zijn of ze zich kunnen identificeren met de doelen van de PLG en of deze aansluiten bij die van henzelf, om - via deelname aan professionele leergemeenschappen - bij te dragen aan professionele ontwikkeling en schoolontwikkeling.

Professionele ruimte in de context van professionele leergemeenschappen (Schaap, Leeferink \& Meijer 2018)

Bovengenoemde studie startte met de gedachte dat PLG's primair tot doel hebben de professionele ontwikkeling van leraren en schoolontwikkeling te bevorderen. Dit veronderstelt dat leraren hiervoor binnen hun school de ruimte krijgen. In dit onderzoek is onderzocht in hoeverre leraren in het voortgezet onderwijs die deelnemen aan een PLG professionele ruimte ervaren. Professionele ruimte is daarbij opgevat als het domein (of de praktijk) waarin leraren, in voortdurende afstemming met zichzelf en anderen (bijvoorbeeld directe collega's of leidinggevenden), zeggenschap hebben over de inrichting en uitvoering van het onderwijs in de klas, het werk en ontwikkelingen op school en hun eigen professionele ontwikkeling. Hierbij is ervan uitgegaan dat 1) professionele ruimte een richting heeft (bijvoorbeeld gericht op het hanteren van een andere didactiek of door leerlingbegeleiding anders aan te pakken), 2) deze ruimte ontstaat en verandert in voortdurende afstemming tussen leraren en hun omgeving (bijvoorbeeld collega's en schoolleiding), en 3 ) het ervaren van professionele ruimte in de loop van de tijd kan veranderen.

Achttien leraren zijn aan het begin en het eind van het schooljaar geïnterviewd over hoe ze hun professionele ruimte ervaren hebben, waarbij de nadruk lag op de mate, richting (professionele ontwikkeling of schoolontwikkeling) en aard (stabiel of veranderlijk) daarvan. Bij stabiele professionele ruimte is sprake van leraren die geen veranderingen in de mate en/of richting van hun professionele ruimte ervaren. Deze achttien leraren maakten deel uit van zes bovenschools georganiseerde PLG's, die ook wel 'netwerk-PLG's' worden genoemd. Het 
primaire doel van deze vorm van professionalisering van leraren is om hun professionele ontwikkeling en schoolontwikkeling te bevorderen. Een netwerk-PLG is een bovenschools georganiseerde samenwerking tussen leraren die zowel vakgebonden (bijv. wiskunde of Engels) als thematisch (bijv. differentiatie) kan zijn, waarbij onder leiding van een externe coördinator samengewerkt wordt aan een product met als doel de bevordering van professionele ontwikkeling van deelnemende leraren en schoolontwikkeling.

De resultaten laten zien dat leraren gemiddeld een te geringe mate van professionele ruimte beleven voor schoolontwikkeling, maar wel voor professionele ontwikkeling. Meer specifiek zijn vijf categorieën van professionele ruimte te onderscheiden: 1) in sterkere mate professionele ruimte ervaren voor professionele ontwikkeling dan voor schoolontwikkeling (stabiel; dit wordt het gehele jaar zo door leraren beleeft), 2) in sterke mate professionele ruimte ervaren voor professionele ontwikkeling en voor schoolontwikkeling (stabiel), 3) in sterke mate professionele ruimte voelen voor professionele ontwikkeling en een afname van schoolontwikkeling (veranderlijk; leraren ervaren hierin veranderingen gedurende het schooljaar), 4) in geringe mate professionele ruimte beleven voor zowel professionele ontwikkeling als schoolontwikkeling (stabiel) en 5) in toenemende mate professionele ruimte ervaren voor professionele ontwikkeling en schoolontwikkeling (veranderlijk). Geconcludeerd wordt dat de beleefde professionele ruimte over het algemeen een stabiel karakter heeft en dat de mate en richting daarvan afhankelijk zijn van de persoonlijkheid van de leraar (zoals intenties) en kenmerken van de schoolcontext (zoals secties en schoolleiding).

De resultaten laten verder zien dat de ervaren professionele ruimte per leraar zich verschillend manifesteert. Hieraan liggen mogelijk interacties en specifieke combinaties tussen persoonlijke kenmerken van leraren en contextuele kenmerken van de school ten grondslag, waarbij PLG's an sich positief worden ervaren door leraren. De volgende uitspraak illustreert dit: "Gewoon er uitbreken, letterlijk uit je eigen school stappen, betekent letterlijk uit je eigen dagelijkse praktijk stappen en betekent vrijdenken, en als je dan mensen tegenkomt die je niet kent en die daar vanuit dezelfde motivatie zitten, dan gebeurt er wat, wat eigenlijk in je eigen school - nou ja - ondergesneeuwd is, onder het tapijt geveegd is of in de cultuur is verdwenen. Zaken die uit de interviews naar voren komen, zijn bijvoorbeeld de intenties van leraren en de rol van secties en schoolleiding. Leraren die professionele ruimte hebben ervaren voor met name schoolontwikkeling lieten een sterke en positieve intentie zien om daadwerkelijk een bijdrage te leveren aan schoolontwikkeling. Leraren in deze studie met een sterke motivatie voor schoolontwikkeling ondernamen dan ook gerichte activiteiten om schoolontwikkeling te bevorderen, zoals het expliciet betrekken van de schoolleiding bij curriculumvernieuwing, het organiseren van een projectweek en die laten opnemen in het standaardcurriculum, het ontwikkelen van een website voor leraren binnen en buiten de eigen school of het opzetten van een PLG voor collega's.

Leraren ondernemen dus zelf ook allerlei activiteiten om hun professionele ruimte te vergroten. Wat betreft contextfactoren geven vooral leraren die in mindere mate professionele ruimte hebben ervaren voor schoolontwikkeling aan dat dit voornamelijk komt omdat de PLG 'losstaat' van wat er op school gebeurt en dat de schoolleiding nauwelijks betrokken is bij de koppeling tussen de PLG en lopende activiteiten op school. Eén leraar zegt hierover: "Ik heb nauwelijks invloed op schoolontwikkeling. Er is geen tijd om mijn ideeën te delen met anderen in de school. Ik ben op school alleen maar aan het rennen, rennen, rennen..." Ook geven leraren vaak aan dat in hun sectie weinig ruimte is voor betekenisvolle gesprekken over bijvoorbeeld goed onderwijs.
Spanningen van leraren die deelnemen aan professionele leergemeenschappen (Schaap, Louws, Meierink, Oolbekkink-Marchand, Van Der Want, Zuiker, Zwart \& Meijer 2019)

Net als in het onderzoek van Schaap, Leeferink en Meijer (2018) zijn in dit onderzoek leraren geïnterviewd die hebben deelgenomen aan een bovenschools georganiseerde netwerk-PLG. Hun onderzoek liet zien dat professionele ruimte en de richting, aard en mate daarvan per context en door de tijd heen sterk kan variëren zeker als onderscheid wordt gemaakt tussen professionele ontwikkeling en schoolontwikkeling. Daarom is in dit onderzoek door Schaap en zijn collega's specifiek ingegaan op spanningen die leraren ervaren als er van hen verwacht wordt dat ze enerzijds leren en professionaliseren in en door de PLG, en hiervan anderzijds ook kunnen overbrengen op de eigen school.

Het overgrote deel van de leraren die we geïnterviewd hebben, zegt dat hij eenmaal of meerdere malen spanningen heeft ervaren gedurende het koppelen van de PLG aan de eigen schoolpraktijk. Die spanningen zijn te categoriseren in drie typen: 1) spanningen die te maken hebben met werkdruk, 2) spanningen die verband houden met de behoefte aan samenwerking en 3 ) intra-psychologische spanningen (binnen de persoon van de leraar). Meer concreet konden we m.b.v. de interviews acht verschillende spanningen achterhalen:

\section{Spanningen als gevolg van werkdruk:}

1. Persoonlijke betrokkenheid bij het stimuleren van het leren van leerlingen versus hoge werkdruk in het primaire onderwijsproces (veel taken);

2. Behoefte aan ruimte en tijd voor eigen ontwikkeling versus intensieve en onvoorspelbare activiteiten binnen en buiten de lessen

3. Motivatie en verantwoordelijkheidsgevoel voor het stimuleren van leerlingen bij het leren versus een gebrek aan structurele ondersteuning en praktische faciliteiten.

Spanningen als gevolg van samenwerking:

4. Behoefte aan een gemeenschappelijke visie op leren versus verschillende of vaststaande visies;

5. Behoefte aan waardering en positieve feedback versus gebrek aan betrokkenheid of investering (noch van leidinggevenden, noch van collega's);

6. Behoefte aan samenwerking en ruimte in de school versus een conservatieve leercultuur in de vaksecties en de school in het algemeen.

Intra-psychologische spanningen:

7. Motivatie om impact van deelname aan de PLG te vergroten versus twijfelen aan de impact van de PLG als middel;

8. Motivatie om te leren versus twijfel aan eigen kwaliteiten als leraar (om de verbinding tussen de PLG en de school tot stand te brengen).

Vooral spanningen van het type 3, 4 en 6 zijn relatief vaak waargenomen. Alle spanningen hebben laten zien dat leraren positieve en krachtige betrokkenheid met hun leerlingen tonen of - algemeen - in de school, voortkomend uit een persoonlijke behoefte of motivatie die ze expliciet uitspreken. Eén leraar verwoordde dit als volgt: "Door deelname aan de PLG heb ik weer een klein stukje van mijn passie voor onderwijs terug. Want eigenlijk ben ik wel een beetje klaar met docent zijn. Ik heb zoiets van, nou, ik vind het wel prima en ja, ik wil wel wat andere dingen gaan doen." Juist de koppeling aan de context van de eigen school maakt het vergroten 
van de impact van PLG's tot een complexe aangelegenheid. Hiervoor lijkt het expliciet afstemmen tussen de PLG en de school als leeromgevingen een belangrijk ontwerpprincipe. Of zoals Kessels (2018) het in zijn reflectie op dit onderzoek verwoordde in Pedagogische Studiën: "Vanuit een klassiek transfer-perspectief kan men de begeleide, bovenschoolse PLG-activiteiten opvatten als een off-the-job professionaliserings-praktijk. De leeropbrengsten zijn in de regel gunstig en de beleving van de deelnemers is positief. Het gaat mis in de transfer naar schoolverbetering als de lokale condities niet meewerken en er een gebrek is aan afstemming met de dagelijkse werkomgeving" (p. 221). Kessels pleit voor een ecologische benadering om de complexe dynamiek tussen leraar, klassen en leerlingen, ouders, schoolleider, team, sectie, structurele voorzieningen, leercultuur en schoolklimaat beter te begrijpen en waar nodig te verbeteren. Voor het creëren van professionele ruimte stelt Kessels (2018) voor de huidige stabiele ecologie te doorbreken (zoals een doorbreken van niveaus en vakken),

bijvoorbeeld door een grondige herziening van de praktische inrichting van het werk en meer situationeel leiderschap in scholen.

\section{Conclusie: professionele leergemeenschappen als situationeel vraagstuk}

Het aantal wetenschappelijke en praktische publicaties over PLG's is zo groot, dat er enkele reviewstudies nodig zijn om een goed overzicht te kunnen krijgen van wat we weten over het functioneren en de ontwikkeling van PLG's, en over de effecten ervan. De twee meest recente en ook meest geciteerde reviews van PLG's zijn die van Stoll et al. (2006) en Vescio, Ross en Adams (2008): anno 2020 is hier respectievelijk ruim 2200 en 2300 keer naar verwezen. 4

Stoll en collega's stelden dat de effectiviteit van PLG's wordt bepaald door 1) een gezamenlijke visie, 2) collectieve verantwoordelijkheid, 3) reflectief en onderzoeksmatig werken ('reflective professional inquiry'), 4) samenwerking en 5) gecombineerd individueel en collectief leren.

Op grond van eigen onderzoek voegden zij hier nog aan toe: 6) een veilige leeromgeving en 7) openheid en partnerschap. Met 'openheid' wordt bedoeld dat een PLG niet beperkt wordt to een kleine groep leraren, maar dat zowel leraren, schoolleiders, management en ondersteuning interactief deel kunnen uitmaken van een PLG. In de bovengenoemde reviews wordt geconcludeerd dat PLG's de potentie hebben om duurzame verandering te bewerkstelligen, alsook dat het goed organiseren van PLG's gecompliceerd is.

Vescio, Ross en Adams (2008) onderscheiden net iets andere vijf kenmerken voor het vaststellen van de effectiviteit van PLG's dan Stoll en zijn collega's, namelijk: 1) gedeelde normen en waarden, 2) focus op het leren van leerlingen, 3) reflectieve dialoog, 4) deprivatisering van eigen praktijken (hetgeen betekent dat leraren de deur van hun klaslokaal openzetten voor feedback en reflectie op hun lessen) en 5) samenwerking binnen de PLG. Ook deze auteurs concluderen dat de door hen gereviewde artikelen een positief beeld laten zien van de impact van PLG's, zowel op de veranderende handelwijze van leraren als op het leren van leerlingen. Beide reviews impliceren dat de effectiviteit van PLG's toeneemt naarmate ze meer tegemoetkomen aan de genoemde kenmerken.

Alle bovengenoemde rijtjes ten spijt, blijft het duurzaam organiseren van leren met behulp van PLG's complex en vooral situationeel van aard. Daarbij moeten het ontwerp en de aansturing - wat betreft het proces en het product - steeds heroverwogen en afgestemd worden op de specifieke context en situaties van leraren en de context van hun schoolorganisatie. Het gevaar ligt op de loer dat bijvoorbeeld beleidsmakers, onderzoekers, adviseurs of schoolleiders dergelijke 'rijtjes' als een wondermiddel gaan zien in de zin van: 'Als voldaan is aan een aantal specifieke kenmerken, dan komt het goed met de PLG' of 'Een PLG is per definitie een effectief middel voor professionalisering van leraren en schoolontwikkeling, mits aan een aantal voorwaarden wordt voldaan.' Het tegenovergestelde is namelijk waar.

Ik heb in dit hoofdstuk laten zien dat PLG's een vorm zijn van peer collaboration tussen leraren (dat wil zeggen: samenwerking tussen leraren als gelijke partners), wat een beroep doet op co-creatie in de context van de schoolorganisatie. Dit maakt dat de ontwikkeling ('creatie') van professionele kennis gesitueerd is (men noemt dat vaak 'enacted') in de dagelijkse praktijk van leraren en de context waarin zij werken en leren. Met andere woorden: embedded cognition, kennis, ontstaat in de interactie van leraren met hun omgeving en met elkaar (De Jong 2019).

Het voorbeeld van Marieke dat ik aan het begin van dit hoofdstuk heb opgevoerd, illustreert het belang van gesitueerde, professionele kennis. Ze heeft interessante dingen ontwikkeld in de PLG, maar deze nieuwe inzichten worden niet automatisch overgenomen in de school.

Of anders gezegd: ze ervoer een gebrek aan eigenaarschap op school, zowel bij collega's als bij haar leiding. Collega's van Marieke vonden dat de kennis buiten de school was ontwikkeld. Ze hadden er geen beeld bij en konden die nieuwe kennis moeilijk vertalen naar de eigen praktijk.

Het belang van deze situationele aard van professionele kennis wordt opvallend genoeg in slechts enkele artikelen uitgewerkt als het PLG's betreft. Eén van de artikelen waar hierop expliciet wordt ingegaan is dat van Riveros, Newton en Burgess uit 2012, die een poging doen de situationele aard van PLG's te ontrafelen. Naar dit werk is een kleine tweehonderd keer verwezen, 5 wat aanzienlijk minder vaak is dan naar artikelen die (effectieve) kenmerken van PLG's onderzoeken. De auteurs werkten het situationele perspectief op leren uit in drie verschillende elementen, vrij vertaald als 1 ) leren is niet alleen een cognitief proces (met het hoofd), maar tevens een proces dat hart en handen aangaat (in de literatuur ook wel 'embodiment' genoemd), 2) leren vindt plaats in een sociale en ecologische omgeving (en maakt daar gebruik van, ook wel 'embedding' genoemd) en ten slotte 3) leren gaat over de eigen grenzen heen, zowel fysiek als mentaal (ook wel 'extension' genoemd).

Wat opvalt aan de manier waarop PLG's momenteel vaak worden georganiseerd - zeker in Nederland -, is dat wordt ingezet op leren als sociaal proces (vaak vormgegeven door in PLG's verschillende leraren met een facilitator en/of begeleider te laten samenwerken), maar dat dit sociale proces vaak gescheiden wordt van de ecologische context van scholen, namelijk de interactie tussen leraren, kinderen, school en samenleving (responsief leren; De Jong 2019). Samen leren is dus maar een deel van wat Riveros, Newton en Burgess (2012) 'embedded learning' noemen. Verder wordt het leren in PLG's, en vooral ook de wijze waarop dat wordt aangestuurd, vooral vormgegeven in het ontwerpen van nieuwe vormen van onderwijs, organiseren van projecten of het doen van praktijkgericht onderzoek. Daarbij wordt vaak feedback gegeven door PLG-begeleiders en input verkregen middels het lezen van literatuur of de inbreng van experts. Verschillende onderzoeken laten zien dat leren in PLG's vooral gericht is op het (verder) ontwikkelen van kennis en vaardigheden, maar dat het slechts in 
enkele gevallen leidt tot een vorm van leren die het cognitieve niveau overstijgt. In het onderzoek over professionele ruimte in de context van PLG's zagen we bijvoorbeeld ontwikkeling en toepassing van nieuwe pedagogisch-didactische vaardigheden, of leraren die leerden om praktijkgericht onderzoek te doen, maar tevens dat dit niet leidde tot reflectie op de eigen visie of professionele identiteit als leraar.

Beide reflecties over embodiment en embeddedness beïnvloeden het derde element van situationeel leren, namelijk extension. Vaak zijn PLG's en scholen twee los van elkaar staande entiteiten die de deelnemers aan elkaar dienen te verbinden. Dit roept direct verschillende transferproblemen op vanwege de verschillende aard en structuur van PLG's en scholen. Waar PLG's bijvoorbeeld meer een beroep doen op langdurig cyclisch werken, staat in scholen veela de 'waan van de dag' centraal. Tevens ervaren leraren de PLG vaak als expliciete leeromgeving voor zichzelf, terwijl scholen worden ervaren als een werkomgeving (of anders gezegd: primai als leeromgeving voor leerlingen). In dat opzicht wordt het leren in PLG's belemmerd, omdat vooral de fysieke grenzen tussen PLG's en scholen moeilijk overbrugd of veranderd kunnen worden. In de literatuur wordt dat juist gezien als één van de belangrijkste voorwaarden of condities voor een effectieve PLG (zie o.a. Stoll et al. 2006).

Concluderend kan men stellen dat het situationele perspectief op leren een aantal tekortkomingen zichtbaar maakt over de wijze waarop PLG's worden georganiseerd, meer specifiek over hoe het leren in PLG's wordt georganiseerd en welke impact dat heeft op de professionele ontwikkeling van leraren en op schoolontwikkeling. De kritiek is vooral gericht op de loskoppeling van PLG's en scholen (als twee aparte entiteiten), de eenzijdige manier van leren in PLG's (die zich meer bezighoudt met kennis en vaardigheden) en de beperkte kijk op de ecologie van de school.

Vanuit deze kritische reflectie heb ik een zestal vragen geformuleerd die ondersteuning kunnen bieden bij de keus voor het soort, en de uitwerking van PLG's. Deze vragen betreffen thema's die ook als kijkkader gebruikt kunnen worden, bijvoorbeeld door schoolleiders die PLG's in hun school willen opzetten. Ik heb hierbij niet alleen geprobeerd de interactie tussen persoonlijke factoren (zoals motivatie en intenties) en contextuele factoren (bijv. leercultuur of leiderschap) te expliciteren, maar ook om het belang van continue afstemming van professionele ruimte te benadrukken (Meijer, Oolbekkink, Leeferink, Schaap, Meirink, Van der Want, Zwart, Louws \& Zuiker 2018). Die zes vragen zijn:

1. Wat zijn de verwachtingen en motieven van leraren en schoolleiders die willen deelnemen aan een PLG? Wat zijn overeenkomsten en verschillen?

2. Hoe wordt deelname aan een PLG vanuit de school geborgd? O.a. in hoeverre is er ruimte om de uitkomsten van de PLG te koppelen aan schoolontwikkeling? Bij welke visie sluit dit aan?

3. Daarop voortbouwend: wat is de rol van de schoolleiding hierbij gedurende het gehele schooljaar of gedurende meerdere schooljaren?

4. Hoe kan deelname aan een PLG zorgen voor professionele ontwikkeling van leraren én voor schoolontwikkeling? Hoe kan dit versterkt worden? Hoe sluit de PLG bijvoorbeeld inhoudelijk aan bij actuele onderwijsontwikkelingen op school?

5. Hoe kan er een dusdanige wisselwerking tussen de PLG en de school gecreëerd worden opdat een cyclus van feedback en reflectie tot stand komt die voeding kan geven aan zowel de reflectieve dialoog in PLG's als de professionalisering van leraren en schoolontwikkeling? 6. Hoe is de leercultuur op scholen in het algemeen, zijn er secties in het bijzonder te typeren, en in welke mate kan dit de impact van enerzijds deelname aan en anderzijds de impact van een PLG bevorderen of belemmeren?

Een meer fundamentele vraag die hieraan voorafgaat is of PLG's wel het juiste middel zijn om bepaalde doelen in schoolorganisaties te bereiken. Vaak wordt aangenomen dat PLG's hiertoe een krachtig instrument vormen, maar dit veronderstelt niet in de laatste plaats dat ze dienen aan te sluiten bij onder andere verwachtingen van leraren en schoolleiders, de leercultuur in voornamelijk bestaande teams/secties en de structuur van de schoolorganisatie. Of, zoals Stoll en collega's al in 2006 concludeerden: het organiseren van PLG's "is by no means easy. A number of subtle as well as more overt processes require work, and there are influences, both within and external to schools that can either facilitate or severely inhibit the process.

Nonetheless, it also demonstrates that PLCs appear to be worth the considerable effort put in to creating and developing them, although there is still much more to learn about sustainability" (p. 247). Die conclusie is nog steeds springlevend.

Ik heb met deze bijdrage gepoogd inzicht te geven in de situationele aard van PLG's. Het verkennen en afstemmen van professionele ruimte in een ecologische context lijkt een belangrijk middel om PLG's duurzaam in te zetten voor professionalisering van leraren en schoolontwikkeling (Kessels 2018).

\section{Referenties}

De Jong, F. (2019). Kennis in-(ter)-actie: responsief leren als kennis construeren. Heerlen: Open Universiteit.

Kessels, J. W. M. (2018). Ecologie van de professionele ruimte. Pedagogische Studiën, 95, 220-226.

Lomos, C., Hofman, R. H., \& Bosker, R. (2011). Professional communities and student achievement: meta-analysis. School Effectiveness and School Development, 22, 121-148.

Meijer, P., Oolbekkink, H., Leeferink, H., Schaap, H., Meirink, J., Van der Want, A., Zwart, R., Louws, M., \& Zuiker, I. (2018). Drie professionaliseringsinitiatieven onder de loep: de professionele ruimte van leraren in de context van professionele leergemeenschappen, de promotiebeurs en traineeships voor leraren. Eindrapportage. NRO, https://www.nro.nl/ kb/405-14-403-zeggenschap-en-professionele-ontwikkeling-van-leraren-in-hetvoortgezet-onderwijs, project 405-14-403, Radboud Universiteit, Nijmegen.

Riveros, A., Newton, P., \& Burgess, D. (2012). A Situated Account of Teacher Agency and Learning: Critical Reflections on Professional Learning Communities. Canadian Journal of Education, 35, 202-216.

Schaap, H., Louws, M., Meirink, J., Oolbekkink-Marchand, H., Van Der Want, A., Zuiker, I., Zwart, R., \& Meijer, P. (2019). Tensions experienced by teachers when participating in a professional learning community. Professional Development in Education, 45, 814-831.

Schaap, H., Leeferink, H., \& Meijer, P. C. (2018). Professionele leergemeenschappen in he voorgezet onderwijs: ervaren professionele ruimte voor professionele ontwikkeling en schoolontwikkeling. Pedagogische Studiën, 95, 132-152. 


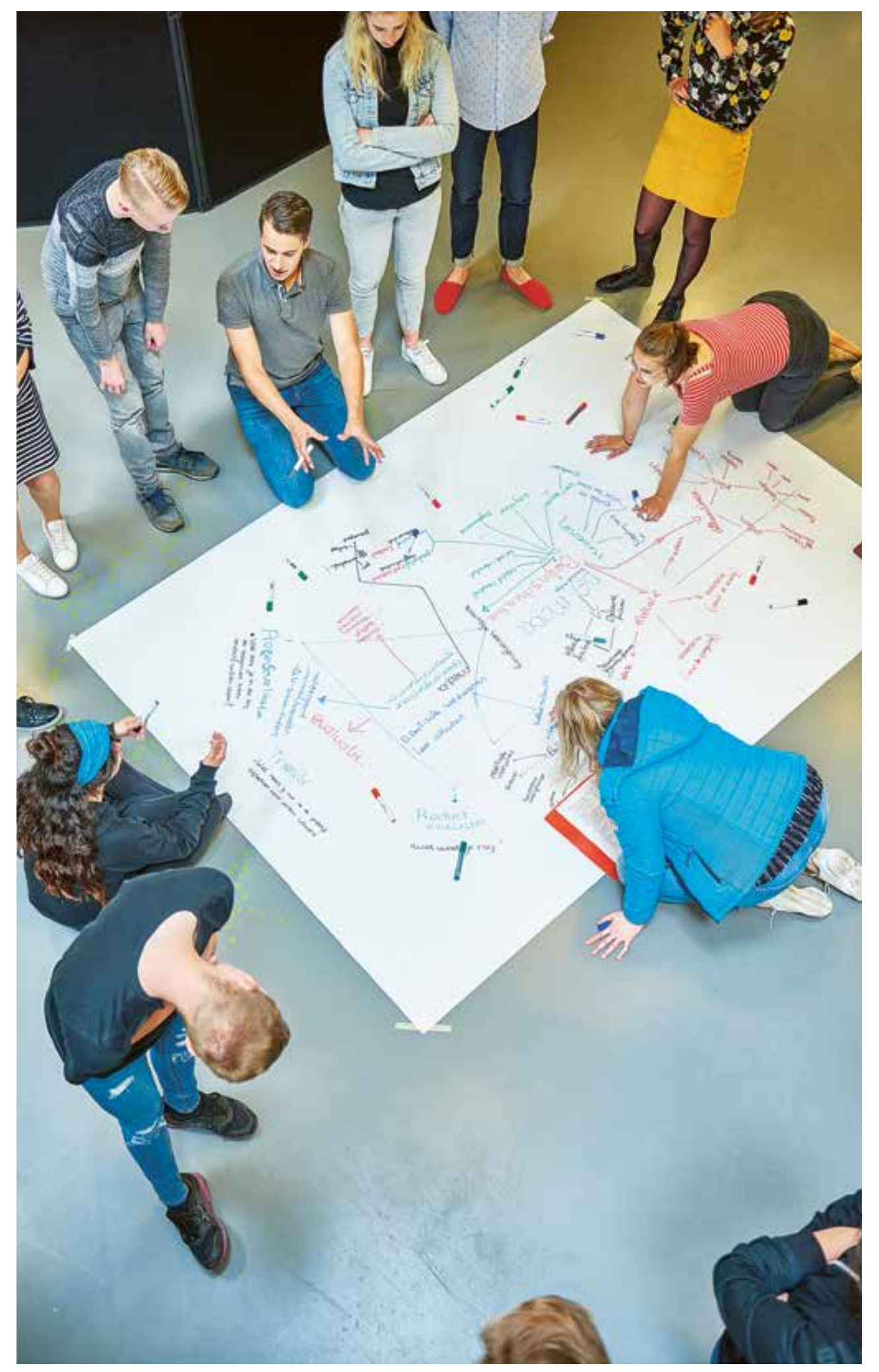

Schaap, H., \& De Bruijn, E. (2018). Elements affecting professional learning communities in schools. Learning Environment Research, 21, 109-134.

Schaap, H., Leeferink, H., Louws, M., Oolbekkink-Marchand, H.W., Meirink, J.A., Van der Want, A., Zwart, R.C., Zuiker, I., \& Meijer, P.C. (2017). Professionele ruimte van leraren in professionele leergemeenschappen. Eindrapportage. NRO, https://www.nro.nl/kb/405-14403-zeggenschap-en-professionele-ontwikkeling-van-leraren-in-het-voortgezetonderwijs, project 405-14-403, Radboud Universiteit, Nijmegen.

Schaap, H., \& De Bruijn, E. (2015). Professionele leergemeenschappen in scholen: een kwestie van eigenaarschap en professionele ruimte. Tijdschrift voor lerarenopleiders, 36, 23-40.

Schenke, W., Sligte, H., Admiraal, W., Buisman, M., Emmelot, Y., Meirink, J., \& Smit, B. (2015). Scan School als Professionele Leergemeenschap. Rapport: 938 ISBN: 978-94-6321-000-3. Kohnstamm Instituut, Amsterdam.

Stoll, L., Bolam, R., McHanon, A., Wallace, M., \& Thomas, S. (2006). Professional learning communities: A review of the literature. Journal of Educational Change, 7, 221-258.

Vescio, V., Ross, D., \& Adams, A. (2008). A review on the impact of professional learning communities on teaching practice and student learning. Teaching and Teacher Education, 24, 80-91. 


\section{PLG-ervaringen vanuit het perspectief van management, deelnemers en facilitator}

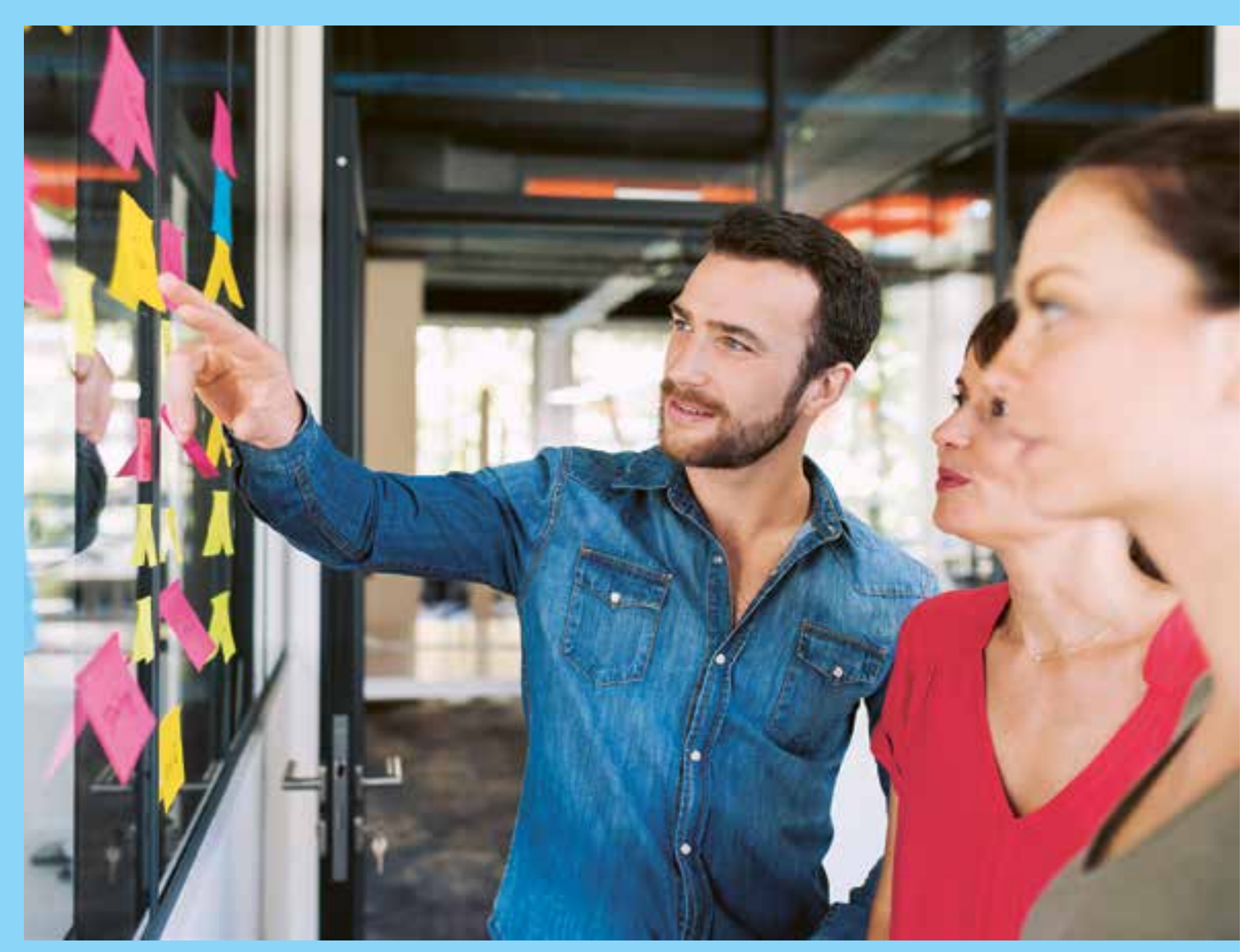

PLG 'Kwalitatieve verbetering van het onderwijs': ervaringen vanuit drie perspectieven

Janny Rijks, Rianne Visser en Laura van Esveld, Mavo-schoolteam-PLG

Wilbert Waggelink en Ellen Messing, Aeres Hogeschool Wageningen (AHW)

\section{Deelnemers}

Het gehele team nam deel aan de PLG.

\section{Aanleiding en perspectief van het management}

De school stond al enkele jaren onder toezicht van de onderwijsinspectie. Er waren al vele pogingen tot verbetering gedaan, maar het ene na het andere plan faalde. Daarnaast vertoonde het schoolteam tekenen van verwaarlozing. De school werd top-down

aangestuurd, alhoewel je beter kunt spreken van een niet aangestuurde school. Docenten en ondersteunend personeel deden zo goed mogelijk hun best te overleven. Eigenlijk kon je niet spreken van een team, slechts van individuen; men ervaarde een onveilig werkklimaat. Onder leiding van een nieuwe directeur werd opnieuw een verbeterplan opgesteld, deze keer door het onderwijspersoneel zelf. Dit leidde uiteindelijk tot een 'nieuw' team met de ambitie: "talent voor groei voor elke leerling, maar ook voor elk personeelslid".

In het betreffende schooljaar was om de vier weken een 'professionele ruimte' ingepland. Deze tijd werd echter niet echt benut met professionele ontwikkeling, maar vooral besteed aan 'to do-zaken', zoals toetsen nakijken en sectieoverleg. Soms gingen mensen dan ook gewoon naar huis. Als docenten wisten we eigenlijk niet zo goed wat we met deze ruimte voor professionele ontwikkeling moesten doen. Ten slotte kwamen we tot de conclusie dat we nog geen professionele, lerende organisatie waren en handelingsverlegen waren richting de leerling, waarbij ouders de lat erg hoog legden en er een groot motivatieprobleem onder de leerlingen bestond.

Wat te doen? We besloten de 'professionele ruimte' voorlopig niet langer in te vullen, maar eerst te onderzoeken wat we überhaupt wilden leren. Om die reden werd een PLG gestart onder leiding van professionals van Aeres Hogeschool Wageningen. Er vonden negen sessies plaats, waarbij elke collega een eigen leervraag opstelde, passend bij datgene wat in het primaire proces van belang was en aansloot bij het teamplan (hierin stonden vooral gedragsindicatoren die pasten bij de competenties van een docent centraal).

De PLG-bijeenkomsten werden als nuttig ervaren. Hierdoor ontstond ruimte om discussies te voeren over leren, en alleen al door de dialoog werd er geleerd. Experts op het gebied van leervragen werden binnengehaald en studenten kregen de kans feedback te geven. De conclusie was dat we misschien wel te ambitieus waren en dat we het onderwijs anders moesten gaan inrichten om beter aan te sluiten bij wat de leerlingen willen en kunnen. Aan het eind van de begeleide PLG's liet het team weten dat het wilde doorgaan met twee PLG's die gericht zouden moeten zijn op de didactische en de pedagogische omgeving. Centraal stond onderwijs op maat, waarbij gewerkt zou worden met leerdoelen, niet met lesdoelen. 
Deze doelen zijn opgenomen in een teamplan. Daarnaast is bekeken of we wel voldoende tijd hadden om die doelen te behalen. We wilden niet langer puur ambitieus zijn, maar in de eerste plaats realistisch. Dat is de belangrijkste les die we van de PLG's geleerd hebben.

\section{Perspectief van de deelnemers}

Ons team is een PLG begonnen omdat we onder toezicht stonden van de inspectie. Het management (MT) gaf ons de mogelijkheid om, via een PLG en onder begeleiding van Aeres Hogeschool Wageningen, het onderwijs te verbeteren. Daarnaast wilden we ons team zelf natuurlijk ook verbeteren. De PLG heeft ons geholpen inzicht te krijgen in de verschillende zaken die wij als team en als individuele docenten zouden kunnen aanpakken. We begonnen met het formuleren van onze eigen leervragen, om vervolgens te kijken of we die leervragen binnen het team konden bundelen in werkgroepjes. Deze werkgroepjes gingen aan de slag met onderwerpen als internationalisering en differentiatie.

De belangrijkste ervaringen en leeropbrengsten deden we op tijdens de gesprekken over onderwijs, de inrichting van het onderwijs en de nieuwe ontwikkelingen op onderwijsgebied. Dit heeft binnen ons team geresulteerd in een betere samenwerking, verbreding van kennis en inzet van ieders talenten. Ook de leerlingen merkten dat wij bezig waren met het verbeteren van het onderwijs, bijvoorbeeld door verschillende 'nieuwe' werkvormen in de lessen te hanteren en die lessen op dezelfde wijze op te starten en af te sluiten.

Wat ik persoonlijk geleerd heb van de PLG is dat ik nu verschillende werkvormen tijdens de lessen uitprobeer, die ik met collega's in het team bespreek. Daarnaast heb ik ervaren dat ik het prettig vind dat er nu tijd en ruimte is om met anderen over onderwijs te praten. Het heeft mij geholpen om met mijn eigen leervraag bezig te zijn, en tegelijkertijd ondersteuning te krijgen van mijn collega's. Gouden regels voor het opzetten van een PLG zijn dat iedereen eraan kan bijdragen en z'n eigen leervragen en wensen kan onderzoeken.

\section{Perspectief van de facilitators}

Uitgangspunt was het werken vanuit de leervraag en zo dicht mogelijk bij het primaire proces te blijven. Tijdens de eerste kennismaking met de groep hebben we ons vooral gericht op de energie bij de mensen ("Wat inspireert je in je werk?" "Waarvoor kom je uit bed?"). De volgende vragen waren: "Wat belemmert je in je werk?" - meer om de problemen even een plek te geven. Daarna hebben we daar in de PLG verder geen aandacht meer aan gegeven, wel in de gesprekken met de leidinggevenden. Vervolgens hebben we per deelnemer geïnventariseerd welk onderwerp hij of zij zou willen aanpakken, direct toepasbaar in de eigen klas. De antwoorden hierop hebben wij, als facilitators, geclusterd in thema's en op een bord geschreven. Daarna konden de deelnemers intekenen op het voor hen meest aansprekende onderwerp. Zo ontstonden er spontaan groepjes van 2 à 5 personen, die grotendeels waren samengesteld uit mensen die doorgaans op hun werk niet zoveel contact met elkaar hebben. Groepjes van 3 à 4 personen werkten het beste. Deze groepjes hebben we in de PLG (en tussendoor) de ruimte gegeven om inhoudelijk met elkaar samen te werken, wat we hebben begeleid, steeds met wat minder bijsturing.

\section{Succesfactoren bij het faciliteren van een PLG}

- Geef weinig aandacht aan problemen (vaak op het gebied van het proces) en juist veel aan zaken die energie geven (inhoudelijke vernieuwing).

- Concentreer je op samen leren/collectief leren in kleine groepjes van 3 à 4 personen (2 of 5 werkt niet).
- Begeleid vanaf de zijlijn (bijsturen i.p.v. aansturen) en inspireer, bijv. door gastsprekers uit te nodigen die de PLG-deelnemers samen hebben aangedragen.

- Stel de reflectiemomenten verdekt op; een goede gastspreker is vaak, naast inspirerend, ook confronterend ('automatische reflectie').

- Zorg dat het management zich verantwoordelijk voelt voor het slagen van de PLG (de PLG als onderdeel van een langer traject) en zich faciliterend opstelt (tussen de PLG-bijeenkomsten door dient ruimte te zijn voor afstemming in de groepjes).

- Laat deelnemers elkaar op onderwerp en inhoud vinden, waardoor de mogelijkheid ontstaat de communicatie binnen een team te versterken. Het geven, vragen en ontvangen van feedback kan via het inhoudelijke werken geoefend worden. Je behoeft niet alles in vaktermen te benoemen (net als bij reflectie), maar ga het gewoon doen.

- Vraag geleidelijk aan meer inbreng van de deelnemers en honoreer die expliciet. Daardoor geeft facilitator en het collectieve proces van de PLG de deelnemers de kans een actievere houding aan te nemen. Dat kan bijvoorbeeld via een gastspreker, maar ook door te vragen ideeën aan te dragen voor de opzet van een volgende bijeenkomst. Het gaat erom dat die samen wordt voorbereid.

- Geef kansen om met verschillende partijen buiten het team (management, leerlingen) over inhoudelijke thema's te sparren. Houd dergelijke momenten kort en krachtig (geen ellenlange discussies). Wel eindigen met conclusies en acties op korte termijn. 


\section{PLG 'Bouwen van een gezamenlijke visie op leren': ervaringen vanuit drie perspectieven}

Ton Spierings en Malou Gerbrands, PLG MBO gezamenlijke opleidingsvisie Frank de Jong, Marjolein Wallenaar en Jan Hoed, Aeres Hogeschool Wageningen (AHW)

\section{Deelnemers}

Het voltallige mbo-team nam deel aan dit traject plus een aantal studenten (die niet altijd maar wel vaak aanwezig waren), drie docenten van de Food-opleiding, drie docenten van de opleiding Toegepaste Biologie, de vijf AVO-docenten, de zorgcoördinator, de loopbaancoach, soms een stagiair(e) van de lerarenopleiding van Aeres Hogeschool Wageningen en de teamleider.

\section{Aanleiding en perspectief van het management}

Het mbo op deze schoollocatie is ontstan vanuit een persoonlijke visie op de twee

opleidingen. De beroepsgerichte docenten en de avo-docenten gingen daarin elk hun eigen weg, dus zonder expliciete samenwerking met de opleiding als geheel. Er was geen synergie. Voorzichtig was het mbo de pioniersfase van een startende opleiding aan het ontgroeien en ontstond behoefte om de opleidingen als een functioneel geheel neer te zetten. De studenten ervoeren daardoor steeds meer wat in de vakken van nut was om te leren voor hun toekomstige werk.

De professionaliseringswens van het mbo-team lag dan ook op het terrein van het ontwikkelen van een gezamenlijke visie op leren. Er bestond namelijk behoefte om studenten meer eigenaar te laten worden van hun leerproces, waarbij de losse elementen in de opleiding als een geheel zouden worden ervaren. Daarvoor was het nodig dat de docenten kritisch leerden kijken naar de manier waarop ze, vanuit een daarop aangepast opleidingsplan, hun lessen konden opbouwen en verzorgen. De verschuiving van hun rol op school van docent naar coach begint inmiddels hier en daar zichtbaar te worden

De behoefte aan een grotere professionalisering heeft altijd gespeeld. De manier waarop de school georganiseerd werd, was veelal fragmentarisch en thematisch, soms individueel, dan weer teamgericht. Het beleid van de school was er nu op gericht om professionalisering in te zetten ten behoeve van het team en de studenten. Dat wil zeggen dat collega's hun behoefte aan scholing bij het team op tafel legden en dat het team keuzes maakte ten aanzien van de inzet van de professionaliseringsuren. In de voorgaande jaren heeft zich een professionaliseringsslag voorgedaan op het gebied van leerstijlen, projectmatig onderwijs, it's learning (online-leren omgeving), mbo city en loopbaanoriëntatie (LOB).

\section{Persoonlijke redenen om mee te doen}

Teamleider: Ik wilde het gemeenschappelijke doel van het team graag gerealiseerd zien en had er vertrouwen in dat dat, met de expertise van de AHW-lector en docenten, een goed resultaat zou opleveren.

Deelnemer: Ik wilde mijn vak geïntegreerd zien in het geheel van de opleiding. Tevens wilde ik de intrinsieke motivatie van de student stimuleren. Daarbij heb ik gebruikgemaakt van een contextrijke leeromgeving die naar voren komt uit de sector waarin de studenten in de toekomst aan het werk gaan.

Facilitator: Voor mij was de reden om mij aan te sluiten dat de teamleider bij AHW aanbelde of wij iets konden betekenen in het ontwikkelen van een gezamenlijke visie op leren in een team. Ook het feit dat ik een paar jaar eerder al een dergelijk traject met een deel van het team heb doorlopen (m.b.t. de Beroeps Begeleidende Leerweg, BBL) en ik daar goede herinneringen aan heb, heeft meegespeeld, en tevens dat ik er met een tweede AHW-facilitator over in gesprek raakte, omdat het op haar bureau lag: dat leidde ertoe dat we de facilitering samen verzorgd hebben. We hebben ook nog een derde collega als facilitator ingeschakeld, dit alles na een goed vraag-ontwikkelingsgesprek met de teamleider en een deelnemende docent.

\section{Perspectief van twee deelnemers}

Teamleider: Mijn bezigheden als teamleider dienden te worden afgestemd op het doel dat we met elkaar voor ogen hadden. De initiatieven en het tempo waarin deze worden gerealiseerd kunnen het beste worden bepaald door het team. Soms ontstaan daarbij fricties wanneer de systeemplanning andere dingen vergt dan het team kan leveren.

Deelnemers: Voortschrijdend inzicht maakte het soms nodig de planning bij te sturen. Als onderliggende, sluimerende problematiek en/of ergernissen naar boven kwamen die belemmerend werkten op de uitvoering van het gestelde hoofddoel, dan had het toch de voorkeur eerst die belemmerende zaken aan te pakken, voordat verder werd gegaan met het hoofddoel.

Docent-deelnemer: Het was goed om tijd te nemen om na te denken over een all-over visie. Normaal doe je dat niet gezamenlijk. We hebben nu een gemeenschappelijke visie (roze wolk) waarvan de implementatie per opleiding wellicht in een verschillend tempo zal worden ingevoerd, afhankelijk van wie je als docent kan en nog aan verder ontwikkeling nodig hebt.

Als belangrijke leeropbrengst voor de organisatie (team/locatie/leerlingen) wordt ervaren dat studenten en docenten helemaal niet zo verschillend van elkaar zijn. Ze willen ook vaak hetzelfde al zijn ze zich daar alleen niet zo goed van bewust. De deelnemende studenten weten nu welke stappen de docenten willen zetten om het onderwijs te verbeteren, terwijl dit gewoonlijk onzichtbaar blijft.

Ook de bewustwording van het feit dat individuen in het team een grote behoefte aan veiligheid, waardering en respect hebben, was een belangrijke leerervaring. Hieraan wordt vaak voorbijgegaan. Daarbij bleek ook dat eerst de fundering waarop gebouwd gaat worden op orde moet zijn (opleidingsplan, onderwijsprogramma's, Eduarte etc.).

De belangrijkste opbrengst is dat er nu een gemeenschappelijke visie op leren is. Een eerste aanzet tot implementatie van die visie is gegeven in concrete lessituaties. Hierover heeft nog geen onderling overleg plaatsgevonden, met het gevaar dat iedereen hetzelfde gaat doen. $E$ is dus ook behoefte om verder te kijken. Dat heeft in het jaar daarop laats gevonden onder PLG-begeleiding door AHW-facilitators, alhoewel die bijeenkomsten minder frequent waren.

\section{Perspectief van de facilitators}

Uitgangspunt was om aan te sluiten bij de praktijk van het onderwijs. We daagden docenten uit om in hun 'zone van nabije ontwikkeling' te treden. Dat deden we door met hen hun 
horizon te schetsen en ze te confronteren met discrepanties, dillema's (gaps) daarin met hun huidig manier van werken. De discrepanties proberen te overbruggen door onderliggende redenen, dilemma's met hen bloot te leggen waarom men niet doet wat men graag zou willen. Door de dilemma's te gaan zien als springplanken voor verandering creëerden we een basis voor een collectieve visie en durf om te veranderen.

Het PLG-proces begon met het maken van een Gap-analysis tussen enerzijds de huidige situatie wat zich nu afspeelt ('Wat zijn we nu?') en anderzijds de toekomst (dromen over wat we eigenlijk willen zijn). Daarna hebben de facilitators en Cultuur Historische Activiteit Analyse (CHAT) uitgevoerd met behulp van de bekende activiteitenpiramide en -dilemma's volgens de theorie van 'Change Labs and transformative work' (Engeström \& Young 2001; Engeström, Virkkunen, Helle, Pihlaja \& Poikela 1996; Tuma \& Pratt 1982). De resultaten van die analyse zijn voorgelegd en besproken in de PLG. Op deze wijze zijn belangrijke dromen, dilemma's en redenen 'waarom mensen doen wat ze doen' achterhaald, die potentiële 'springplanken voor ontwikkeling' zijn, of juist het tegenovergestelde (zie fig. 1).

Figuur 1: Analyse van dromen en de huidige situatie en dilemma's en de prioritering door deelnemers

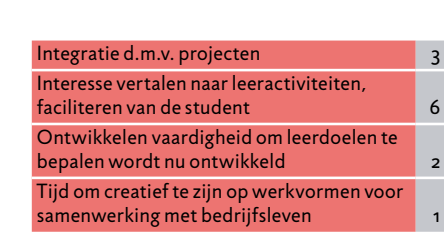

Eigenaarschap van het leerproces
Overkoepelend project: vakken daaraan dienstbaar
Authentieke opdrachten; niet beperkt door $\mathrm{KD} \rightarrow \mathrm{KD}+$ (stou

Authentteke opdrachten; niet beperkt door $\mathrm{KD} \rightarrow \mathrm{KD}+($ sto
(regioleren), leren in bedrijfscultuur; bedrijven adopteren;
Samenwwerking

Leren met de nieuwste technologie; gericht op de toekoms

Gebruik maken van aanwezige faciliteiten in de school
Afwwisseling van lessen en opbouw op je eigen manier

Afwisseling van lessen en opbouw op
Betrokken docenten, interesse in elka

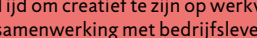
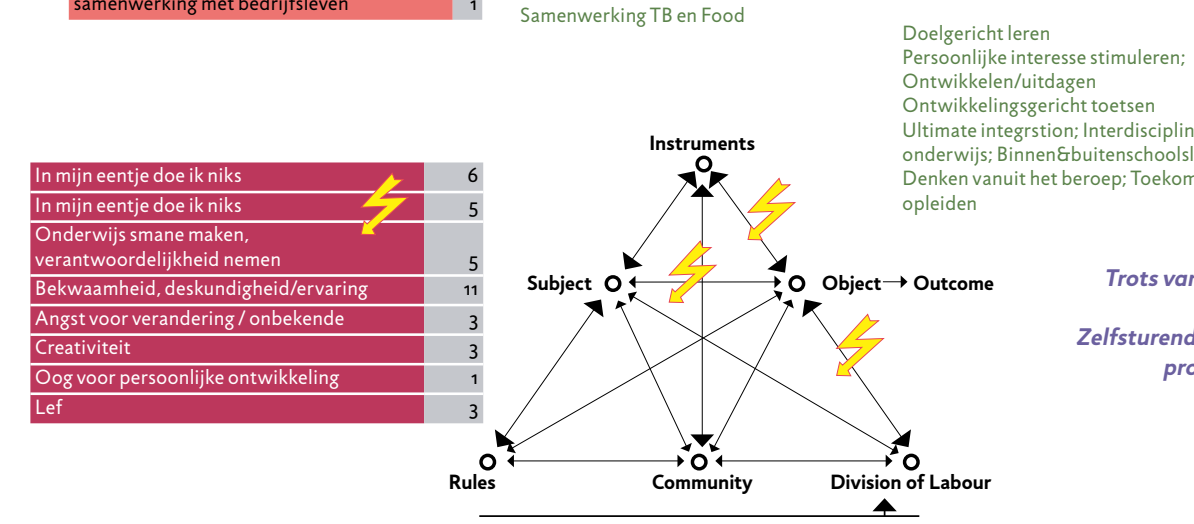
Ontwikkelen/uitdagen

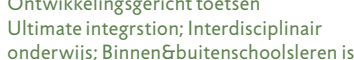

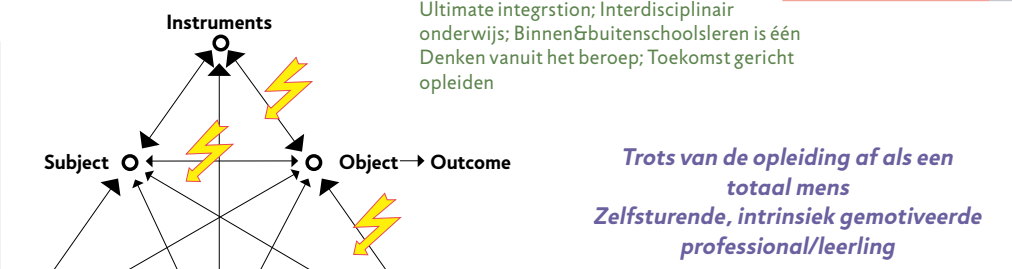

(inspectie, beleid, Viea jaar opleiden Loslaten klassen Loslaten uniforme inhoud
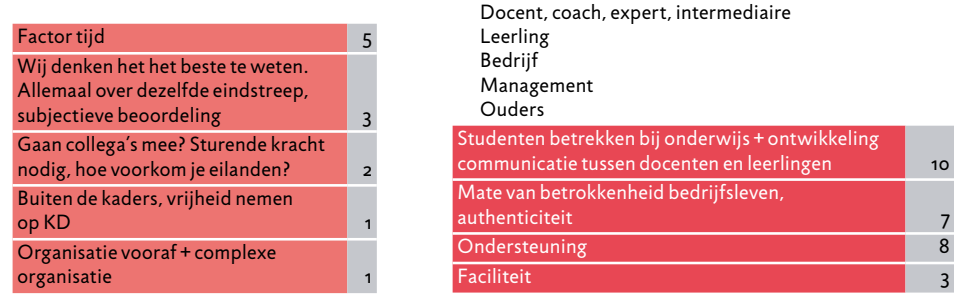

Op basis van de analyses werden de eerste collectieve visies op leren opgesteld. Daarna volgden inspiratiesessies met een diepgaande workshops in de leerpsychologie en het uitwerken van visies in heterogene groepjes. De daaruit voortkomende groepsvisies werden in de vorm van $3 \mathrm{D}$ gevisualiseerde artefacten aan elkaar gepresenteerd (zie afbeelding).

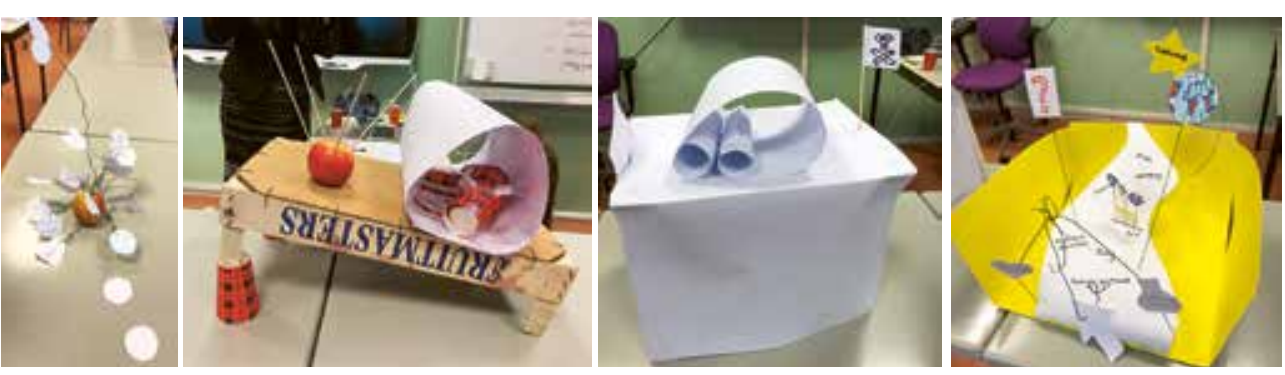

${ }_{3}$ D gevisualiseerde artefacten van de groepsvisie op leren die werden gedeeld in de PLG.

Op grond van dit alles is een gemeenschappelijke visie op leren geformuleerd. De docenten en facilitators zijn vervolgens op een action learning-achtige wijze met deze visie aan de slag gegaan (Hays 2007; Rowley \& Slack 2009). De docenten hebben in heterogene groepjes lessen ontwikkeld op basis van de visie. Het uitproberen van stukjes visie op leren, vormde uiteindelijk de evidence, de kenniservaring, van wat wel en wat niet in de praktijk werkt. De visie(s) zijn aan de hand daarvan bijgesteld. Uiteindelijk is op deze wijze een gezamenlijke evidence based collectieve zienswijze ontwikkeld. Aan het eind van het jaar werd tijdens de eindsessie een lijst van ontwikkelpunten voor het volgende jaar opgesteld. Deze vormde de basis voor een continuering van de PLG, weliswaar met minder begeleiding van AHW en meer uitproberen en concretiseren op het niveau van de lespraktijk.

De facilitators zijn zich er opnieuw bewust van geworden dat faciliteren een vak is. Het is een dynamische bezigheid: altijd doen zich onverwachte gebeurtenissen voor waar je ter plekke mee moet omgaan. Als facilitator moet je je adaptief opstellen en voortbouwen op wat er aanwezig is, maar tegelijkertijd docenten flink in de rug duwen om hun zone van nabije ontwikkeling in te stappen. De inbreng van studenten was heel groot. Dat gegeven vormde een goede leerervaring voor de docenten, want daaruit werd duidelijk dat ze veel meer met hen - eindgebruikers - in gesprek zouden kunnen gaan over onderwijsontwikkeling. Een andere mooie leerervaring bij een dergelijke onderwijsontwikkeling is dat een team open kan staan en zich kwetsbaar durft op te stellen tegenover studenten.

\section{Succesfactoren bij het faciliteren van een PLG}

- Een PLG dient bottom-up gedragen te worden en niet alleen een top-down gebeuren van het management te zijn.

- Er dient voldoende tijd beschikbaar te zijn om te realiseren wat er gerealiseerd moet worden.

- Het is belangrijk om elke persoon in zijn kracht te zetten en te laten doen waar deze en de organisatie beter van worden.

- Het verrijkt het PLG-proces om studenten vanaf het begin te laten meedenken met de te ontwikkelen plannen.

- Belangrijk is om een goede vraagarticulatie uit te voeren en vanuit de praktijk urgentie 
duidelijke vraag, doel en opbrengsten te formuleren. De vraagarticulatie is een co-creatieproces van facilitators, opdrachtgever en betrokkenen docenten (en liefst ook nog van studenten).

- Verder dient er voldoende faciliteiten, budget, capaciteit, tijd en ruimte te zijn voor deelnemende docenten, management en facilitators.

- Aansluiten bij waar de praktijk staat en deelnemers uitdagen in hun zone van nabije ontwikkeling te stappen door een gewenste horizon met hen te schetsen; ze te confronteren met gaps en redenen waarom die er zijn; dilemma's blootleggen waarom men niet doet wat men graag zou willen zijn en doen. Creëer collectiviteit in visie en durf om veranderingen door te voeren.

- Samen gouden regels opstellen voor implementatie van PLG-opbrengsten.

- Doelgericht ideeën invoeren door ze uit te proberen.

- ledereen in de gelegenheid stellen dat op eigen wijze en in zijn eigen tempo te doen.

- Nazorg bieden vanuit het voorbereidingstraject, oftewel begeleiding bij de implementatie en continuering van de PLG.

- Als team en teamleider beschikbaar voor elkaar zijn.

- Studenten blijvend betrekken bij de inhoud en vorm van de opleiding.

\section{Referenties}

Engeström, Y., Virkkunen, J., Helle, M., Pihlaja, J., \& Poikela, R. (1996). The Change Laboratory as a Tool for Transforming Work. Lifelong Learning in Europe, 1(2), 10-17.

Engeström, Y., \& Young, M. (2001). Expansive Learning at Work: Toward an Activity Theoretical Reconceptualization. [and] Contextualising a New Approach To Learning: Some Comments on Yrjo Engestrom's Theory of Expansive Learning. Journal of Education and Work, 14(1), 133-156, DOI: 10.1080/13639080020028747

Hays, J. M. (2007). Dynamics of Organisational Wisdom. Business Renaissance Quarterly, $2(4), 77-112$.

Rowley, J., \& Slack, F. (2009). Conceptions of wisdom. Journal of Information Science, 35(1), 110-119. https://doi.org/10.1177/0165551508092269

Tuma, J. M., \& Pratt, J. M. (1982). A Dynamic Theory of Organizational Knowledge Creation Ikujiro Nonaka. Organization Science, 5(1), 14-37. https://doi.org/10.1037/a0022390

\section{PLG VMBO: management en onderwijsvernieuwing in het VMBO}

\section{Jan Hoed, Aeres Hogeschool Wageningen}

\section{Deelnemers}

Aan deze PLG werd deelgenomen door docenten van het $\mathrm{VMBO}$, van wie twee de rol van teamvoorzitter hadden. Met laatstgenoemden werd vooraf en na afloop de vorm en inhoud van de bijeenkomst besproken.

\section{Aanleiding}

Het betreffende vmbo ging van start met emergente teams. Dit zijn relatief kleine teams waarin hoogwaardige ontmoetingen plaatsvinden tussen leraren en schoolleiders, met als doel het onderwijs te verbeteren (Van der Hilst 2015). Bij het betreffende vmbo zijn deze nieuwe teams met teamvoorzitters aangesteld op alle locaties; de oorspronkelijke teamleiders zijn vervangen. De schoollocaties werden geleid door locatiedirecteuren.

Tegelijkertijd was een vernieuwing van het curriculum in het vmbo gaande. De samenwerking met betrekking tot onderwijsontwikkeling vanuit een breed gedragen visie was dan ook de directe aanleiding om een PLG op te starten. Net als bij de andere beschreven PLG's was al eerder collectief aandacht geschonken aan professionalisering.

\section{Een persoonlijke reden om mee te doen}

Ik (Jan, facilitator) werd benaderd door de afdelingsdirecteuren van de vmbo-locatie. Zelf wilde ik proberen mijn rol in het faciliteren van collectief professioneel te versterken. Daarbij hielp ook een interne AHW PLG. In die PLG gingen de collega facilitators van AHW met elkaar in gesprek om met en van elkaar te leren. Verder heeft AHW een opleiding Dienstverlening en Producten ontwikkeld waarbij een aantal principes zijn toegepast die je terugvindt in literatuur over PLG's - een reden te meer dus om deze kans aan te grijpen."

\section{Perspectief van de deelnemers}

De opvattingen van collega's over het organiseren van onderwijs, het faciliteren ervan en het reageren op de veranderingen daarbinnen verschilden sterk van elkaar. Bij aanvang bestond er geen gedeelde opvatting over leren, over wat men samen wil bereiken met de leerlingen. Er was een afwachtende, soms gereserveerde houding waarbij men niet te snel de inhoud of problematiek opzocht. Een PLG vraagt om een veilig klimaat en de bereidheid om opvattingen expliciet te maken. Verder is een open houding van de deelnemers tegenover ideeën van collega's en nieuwsgierigheid daarnaar van belang.

De rol die het MT speelt, zowel in het faciliteren van activiteiten tussen de bijeenkomsten als in het volgen en stimuleren van collega's, mag niet worden onderschat. In een PLG wordt immers collectief leren georganiseerd op meerdere organisatieniveaus, waartussen processen van wederzijdse aanpassing plaatsvinden (Verbiest 2016). De deelnemers wilden graag dat het MT reageert op de door hen opgeworpen punten. Deze punten werden tijdens de PLG geformuleerd, genoteerd en vervolgens voorgelegd aan het MT. 


\section{Perspectief van de facilitator}

Uitgangspunt was het verbeteren van de communicatie binnen het team door het samen te hebben over de vorm en inhoud, opdat het leren van de vbmo-leerling beter wordt gefaciliteerd. Het doel was enerzijds het zoeken naar een balans tussen aandacht geven aan de manier waarop wordt samengewerkt en heldere verwachtingen van elkaar te krijgen (en de manier waarop dit door het MT wordt gefaciliteerd) en anderzijds de vakinhoudelijke en didactische kant. Het streven was om 1) uit te gaan van en voort te bouwen op wat de deelnemers zelf al deden, 2) ervaringen met elkaar te delen, 3) dit te waarderen en verder 4) te zorgen dat je een team wordt door je gezamenlijk over de inhoud te buigen.

Ook vanuit het oogpunt van balans is het belangrijk dat de sessies productief zijn en dat ze iets concreets - een plan, lesopdracht, nieuwe inhoud of vorm - opleveren. Het is niet de bedoeling dat alleen maar wordt gepraat over betere manieren van samenwerking. Het is mede daarom van belang dat de afdelingsdirecteuren een voelbaar onderdeel vormen van de PLG, wat van die zijde bijvoorbeeld gestimuleerd kan worden door te informeren naar de voortgang en de concrete resultaten.

De periodes tussen de bijeenkomsten bleken belangrijk te zijn. Als er geen tijd of gelegenheid was om ervaringen op te doen, producten te maken en iets voor te bereiden voor de volgende bijeenkomst, werden deze bijeenkomsten als van minder belang ervaren. Het is aan te bevelen dat de deelnemers ook de tijd tussen de bijeenkomsten benutten. Dit punt wil ik een volgende PLG-facilitering goed vastleggen. Het kost tijd en vertrouwen om de samenwerking goed op gang te krijgen. Het expliciteren van ieders opvattingen en deze onderdeel maken van de visie is een cruciaal onderdeel van het programma. Dit wil ik ook benadrukken in de eerste besprekingen over het inzetten van een PLG. Daarnaast moet duidelijk worden wat precies de opzet is, wat het team zelf wil en wat ik moet doen als de doelen tijdens het traject worden bijgesteld. Verder denk ik dat het een verbetering is als je binnen teams projectgroepen maakt. Deze kunnen hun nieuwe inzichten presenteren, onderbouwen, kennis delen, enz.

\section{Succesfactoren bij het faciliteren van een PLG}

- De deelnemer kiest voor een PLG op grond van wat hij erover hoort - wat beoogt deze en conformeert zich aan de inspanning die dat van hem zal vragen. Dat er bewust gestreefd wordt naar een resultaat dat voor iedereen voordelen oplevert.

- We stellen de inhoud en het doel centraal, niet de problemen (bijv. slecht samenwerken,

frustraties in het team uit het verleden enz.).

- We erkennen expliciet elkaars kwaliteiten en professionaliteit.

- Aan het begin wordt duidelijk gemaakt dat de PLG dient te resulteren in beter leren voor de leerlingen.

- De organisatie (MT, directie...) is onderdeel van het collectief (leren), spreekt zich daarover uit en informeert naar de voortgang.

- In het ontwerp van de (gefaciliteerde) PLG-periode is de tijd tussen de bijeenkomsten ook opgenomen.

- Voor implementatie van de PLG-opbrengsten is het belangrijk om de gedeelde resultaten vast leggen, en wel zo dat het verband met de visie zichtbaar is. Zo kunnen ook mensen die nieuw aanschuiven snel en vanuit collectief gedragen opvattingen meedenken en aan de slag gaan.

- Tevens belangrijk voor de PLG-implementatie is het organiseren van 'terugkommomenten' waarop het behandelde geëvalueerd wordt.

\section{PLG 'E-leren en e-didactiek': ervaringen vanuit twee perspectieven}

Ria van Dinteren \& Jan Tiemen Reinders,

Aeres Hogeschool Wageningen \& AOC bovenlocatie-PLG

\section{Deelnemers}

Het $A O C$ heeft meerdere locaties, en allemaal werden ze geconfronteerd met problematiek rond ICT en (on-line) leren. Op sommige locaties werd het onderwijs gegeven in de vorm van leerpleinen, bij andere had die de vorm van gepersonaliseerd leren. Het AOC koos voor een PLG over de locaties heen.

De samenstelling van deze boven-locaties PLG was qua verdeling over de zeven vestigingen prima. Van elke vestiging kwamen twee personen, wat een goed aantal bleek te zijn. Bij de selectie van de deelnemers was niet specifiek aandacht besteed aan hun vakgebied. Het was positief dat alleen deelnemers uit het onderwijzend personeel gevraagd waren. In de praktijk waren het vooral docenten van algemene vakken die aan de PLG deelnamen, met onder hen één vakdocent.

\section{Aanleiding}

Destijds was het $A O C$ net begonnen met de pilot 'Een device voor iedere leerling', nadat twee jaar lang in een werkgroep overleg was gepleegd over de leermiddelenmix en de rol van ICT daarin. Daarom sloot de PLG goed aan bij de actualiteit van deze onderwijsinstelling. Op de AOC-vestigingen was eerder aandacht gegeven aan professionalisering. Meestal vond dat plaats op een studiedag, waaraan de collega's in workshopvorm deelnamen. In veel gevallen was een expert aanwezig die het een en ander vertelde, terwijl de deelnemers grotendeels passief luisterden.

Deelnemende docent: "Voor zover ik weet, komt het weinig voor dat er collectief aandacht is voor professionalisering boven het vestigingsniveau." Het leren van elkaar, wat centraal stond bij de PLG, was iets nieuws.

\section{Een persoonlijke reden om mee te doen}

Jan: "Als medewerker was ik betrokken bij het overleg over de leermiddelenmix en medeverantwoordelijk voor de invoering van de pilot, waarbij elke leerling een laptop kreeg. Het was mijn taak om het docententeam waar nodig te ondersteunen bij de invoering en het gebruik van het device. De PLG als werkvorm was voor mij nieuw en als zodanig niet een reden om deel te nemen. Het idee dat je elkaar als betrokken collega's helpt en motiveert met betrekking tot ICT en de implementatie van ICT in het onderwijs, waarbij je samen de doelen bepaalt en de verdieping zoekt, was echter voor mij op dat moment een ideale kans om me verder te komen in mijn werk op de vestiging."

\section{Perspectief van de deelnemers}

We hebben samengewerkt met docenten die we in de dagelijkse praktijk niet regelmatig tegenkomen (diverse vestigingen). Hoewel er nadelen aan verbonden zijn, heeft dit wat mij betreft toch de voorkeur. De inbreng van de deelnemers is divers en soms anders dan je vanuit de dagelijkse praktijk van je vestiging gewend bent. 
Het werkt goed om langere tijd op een dag ergens voor beschikbaar te zijn. In de PLG was je meerdere uren achtereen bezig, terwijl de meeste activiteiten in het onderwijs kortdurend zijn. Daardoor is er meer ruimte voor verdieping.

We hebben veel geleerd over de ontwikkelingen in het onderwijs, in het bijzonder op ICTgebied. We hebben gezien dat een PLG een werkvorm is waaruit in korte tijd veel informati en motivatie te halen valt. Ook merkten we dat het van belang is dat de deelnemers goed voorbereid moeten zijn op wat meedoen aan een PLG inhoudt, zodat ze niet voortijdig afhaken. Alle deelnemers moeten onder dezelfde voorwaarden meedoen aan de PLG. Deelname aan een PLG moet niet halfslachtig gefaciliteerd worden.

\section{Perspectief van de facilitators}

Als facilitator is je rol en taal ondersteunend. Je creëert ruimte voor leren, begeleid de deelnemers in het bereiken van persoonlijke en teamdoelen en daagt uit om te experimenteren. Meer in detail zijn de uitgangspunten:

- Binnen een PLG leren, door en voor professionals, is gebaseerd op het uitgangspunt dat veel kennis al in de groep aanwezig is en daarop voortgebouwd kan worden. ledereen kent wel een slimme collega die aan het experimenteren is geslagen. Als dat succesvol is, dan heeft het als groot voordeel dat alle hobbels en ondersteuning op de school zelf al ervaren zijn. Daarmee zitten deelnemers die ervaring hebben opgedaan per definitie dichter bij hoe docenten in school leren van hun werk.

- In een PLG wordt geprobeerd de kennis die al bestaat te ontsluiten. Daarvoor is het cruciaal over een facilitator te beschikken die in staat is om voort te bouwen op de ervaringen die in de groep aanwezig zijn, ze minder anekdotische als persoonlijke beleving maar meer de generieke essenties te ontrafelen en daardoor toegankelijk te maken voor anderen.

- Een facilitator voegt tevens kennis toe, zonder die voor te schrijven op het moment dat er bepaalde kennis of ervaring ontbreekt, bijvoorbeeld dat de visie en het effect van leren met ICT met individuele pc's niet voor elke docent duidelijk is. Dan blijkt vaak dat een visie te abstract is en niet vertaald naar gewenst docentengedrag. Door inhoud toe te voegen, het gesprek erover mogelijk te maken, wordt het voor iedereen duidelijk wat wel en niet mogelijk is, en ontstaat ruimte om te experimenteren.

- Experimenteerruimte creëren: in de PLG worden niet alleen kennis en ervaringen gedeeld, maar wordt ook nieuwe kennis ontwikkeld die docenten direct kunnen benutten. In ons geval ging het om experimenteren met online tools, het maken van video's, het werken met studiewijzers en met online-instructies. Wanneer aanwezig hebben docenten presentaties gegeven, bezoeken gebracht aan goede praktijkvoorbeelden (binnen en buiten het AOC) en gewerkt aan zowel eigen als gemeenschappelijke doelen.

- De verworven inzichten zijn niet alleen gedeeld in het eigen team, maar ook met de managers. Er kwam dus direct resultaat en waardering.

\section{Succesfactoren bij het faciliteren van een PLG}

- Deelnemers en de organisaties achter hen conformeren zich aan de PLG. Dit betekent dat ze een bewuste keuze maken voor deelname. Van belang is dat het management dit faciliteert en dat er geen druk wordt uitgeoefend om bijeenkomsten af te zeggen voor andere werkzaamheden (wat regelmatig is voorgekomen op diverse vestigingen).

- Voordat men zich aanmeldt is het belangrijk duidelijk uit te leggen wat een PLG is, hoe deze werkt en wat je ervan kunt verwachten.

- Het helpt als er een facilitator is aangewezen om het proces te begeleiden, al moet een PLG ook zonder coaching mogelijk zijn.
- Een PLG levert vooral voordelen op voor de deelnemers. Een van de leerdoelen van de PLG zou betrekking moeten hebben op de implementatie daarvan in de organisatie.

- Als het een externe of vestiging-overstijgende PLG betreft, dan is het van nog groter gewicht om deze implementatie goed te regelen. De verantwoordelijkheid hiervoor lijkt mij primair bij de deelnemers te liggen. Die krijgen namelijk het een en ander gefaciliteerd, waar de organisatie ook baat bij kan hebben. 


\section{PLG VMBO: 'Leren voor duurzaamheid': ervaringen vanuit drie perspectieven}

Annelies de Waal, Bovenlocatie-PLG leren voor duurzaamheid Stan Frijters en Ellen Messing, Aeres Hogeschool Wageningen

\section{Deelnemers}

De samenstelling van de PLG was qua verdeling over de vestigingen prima. Zes van de acht vestigingen van het vmbo waren vertegenwoordigd. Twee daarvan waren vertegenwoordigd door twee personen, de andere door één. In het tweede jaar van deze PLG kwamen er twee mbo-vertegenwoordigers bij en haakte ook een zevende vestiging aan. Er waren een interne AOC-facilitator en een AHW-facilitator aangewezen. We realiseerden ons dat een systeeminnovatie meer vraagt dan het samenwerken aan de lesinhoud. Daarom is in deze PLG begonnen met deskundigheidsbevordering van duurzaamheidscoördinatoren hoe duurzaamheid te implementeren in school, curriculum en didactiek. Zij werden dan ook wel getypeerd als 'aanjagers'.

\section{Aanleiding}

Het Agrarisch Opleiding Centrum (AOC) wilde, vanuit haar visie op maatschappij en onderwijs, duurzame ontwikkeling structureel inbedden in zijn organisatie. Het betrof zowel het onderwijs als de bedrijfsvoering en de leeromgeving buiten de schoolmuren. Die ambitie moest samen nader verkend worden. Omdat het AOC door middel van een NRO-onderzoek fors had bijgedragen aan de ontwikkeling van ontwerpcriteria voor "Leren voor duurzame ontwikkeling" was het implementeren van de Whole School Approach voor duurzame Ontwikkeling een logische vervolgstap om verder te werken aan duurzame ontwikkeling in het kader van de missie en visie.

Wat ook meespeelde was het feit dat we zoekende waren naar een vorm van onderwijs waarbinnen de motivatie van leerlingen groot blijft. Een van de aannames was dat de leerlingen zelf te weinig centraal staan bij de leeractiviteiten. Het eigenaarschap bij leren is daardoor minder dan mogelijk zou zijn. De didactiek van 'Leren voor duurzame ontwikkeling' vraagt om een actieve deelname van de leerlingen. De eenentwintigste--eeuwse vaardigheden maken hiervan deel uit.

Leren voor duurzame ontwikkeling is vormend (transformatief) en beoogt leerlingen en studenten voor te bereiden op een weloverwogen toekomstige deelname aan een duurzame maatschappij. Unesco formuleerde dit als volgt: "ESD empowers learners to take informed decisions and responsible actions for environmental integrity, economic viability and a just society, for present and future generations, while respecting cultural diversity. It is about lifelong learning and is an integral part of quality education. ESD is holistic and transformational education which addresses learning content and outcomes, pedagogy and the learning environment. It achieves its purpose by transforming society" (UNESCO 2017, 2020).

Op de vestigingen is uiteraard eerder aandacht gegeven aan professionalisering, maar niet specifiek op het terrein van de didactiek voor het leren voor duurzame ontwikkeling, zoals in deze PLG. Op de tweejaarlijkse AOC-brede studiedagen en tijdens de studiedagen over het nieuwe vmbo was duurzame ontwikkeling (DO) in het groene onderwijs, net als LOB, geagendeerd als kern van het nieuwe vmbo, echter nooit eerder zo specifiek en met zoveel aandacht voor de implementatie als een systeeminnovatie. Vakgroepvoorzitters namen DO mee in hun beleidsmatig handelen. Het CC herkende de knelpunten van de didactiek van innovatief onderwijs en besteedde daar extra aandacht aan.

Persoonlijke redenen om mee te doen

Alle PLG-deelnemers waren al betrokken bij duurzaamheidsinitiatieven op de eigen vesting, maar hadden geen locatie-overstijgend onderling overleg. De coördinatie van lopende activiteiten kwam veelal tot stand vanuit extern opgelegde audits (Ecoschool), waarbij het curriculum buiten de aandacht bleef. Werkelijk eigenaarschap bleef mede hierdoor gering. Alle milieucoördinatoren waren door hun directies gevraagd om mee te doen aan de PLG. Vooral het delen van kennis en ervaring met gemotiveerde collega's vormde een drijfveer voor deelname.

\section{Perspectief van de deelnemers}

- Het delen van ervaringen en good practices werd als zeer positief ervaren.

- De facilitators concludeerden echter aan het eind van het eerste jaar dat het omzetten van voornemens om verder te acteren dan waar de Ecoschool om vroeg, veelal moeizaam verliep.

- Onderzoek naar implementatie en interviews met directies leverden veel inzichten op gerelateerd aan het Triade-model (Poiesz 1999). Poiesz bespreekt gedragsveranderingen die het gevolg zijn van een balans tussen motivatie, capaciteit en gelegenheid. Het samenspel van deze factoren moet uiteindelijk tot gedragsverandering leiden.

- Naar aanleiding van een eerder PLG-evaluatie meer werken aan:

- Een andere taakomschrijving (explicieter accent op implementatie, evaluatie en reflectie.

- Het vermogen van PLG-deelnemers om zelf te kunnen doorpakken.

- De complexiteit van de innovatie helder krijgen.

- Betrokkenheid van de gehele school naar voren brengen; onderwijs en onderwijsondersteunend personeel.

- Communicatieve vaardigheden van PLG-deelnemers ontwikkelen.

- Onderzoekende houding van PLG-deelnemers bevorderen.

- Evaluatieve en reflectieve vaardigheden van PLG-deelnemers vergroten.

- De PCD-(kwaliteits)cyclus in het proces van implementatie opnemen.

\section{Perspectief van de facilitators}

Maak de uitgangspunten vooraf heel helder. Laat potentiële deelnemers (her)overwegen of ze mee willen doen aan de hand van een taakbeschrijving.

- Zorg voor een goede onderlinge communicatie en bij voorkeur voor deelname door vertegenwoordigers van diverse geledingen uit de school.

\section{Belangrijke leeropbrengsten voor de organisatie (team/locatie/leerlingen)}

- Naast PLG's zijn er natuurlijk andere zaken die van invloed kunnen zijn op het onderwijs in een organisatie.

- Het proces van denken over goed onderwijs en de toegevoegde waarde van reflectietool Teamsite.

- Doorontwikkeling is een instrument van duurzaam leren. 


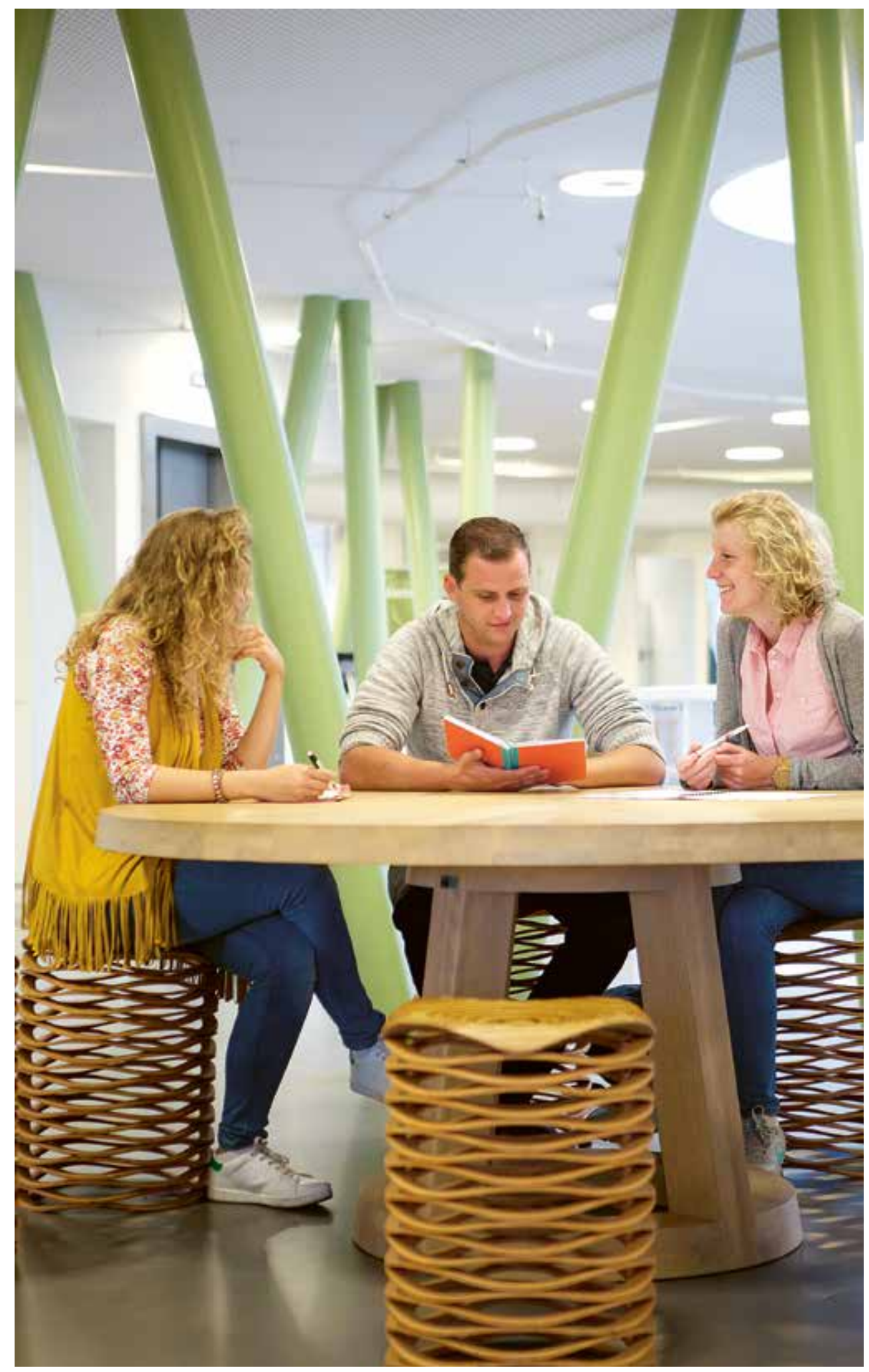

Succesfactoren PLG Leren voor duurzaamheid

- Verbreding en draagvlak bij het MT creëren.

- Continue informeren en communiceren.

- Bindende afspraken met MT's maken.

- Profiel van de PLG-deelnemers opstellen.

- Beeld hebben van de uitgangspunten op grond van motivatie, gelegenheid en capaciteit (Poiesz 1999).

- Het helpt als de facilitator aanwezig is om het proces te begeleiden. Deze moet, behalve coachend, soms ook sturend/corrigerend kunnen optreden.

- Het is nuttig collectief opbrengst-gerichte afspraken met elkaar te maken om een

locatiebelang te dienen, omdat daarmee de implementatie het persoonlijk leren overstijgt.

- Neem opbrengsten van systeeminnovaties op in een meerjarenplanning.

\section{Referenties}

Poiesz, T.B.C. (1999). Gedragsmanagement. Waarom mensen zich (niet) gedragen. Wormer: Inmerc

UNESCO (2017). Teaching and learning for a sustainable furture: a mulitmedia teacher education program. Zie http://www.unesco.org/education/tlsf/

UNESCO (2020). What is Education for Sustainable Development? Zie https://en.unesco.org/ themes/education-sustainable-development/what-is-esd 


\section{Hoofdstuk 4 \\ Autoverhalen tijdens de reis naar en van PLG-bijeenkomsten}

Ton van Wijck, Aeres Hogeschool Wageningen

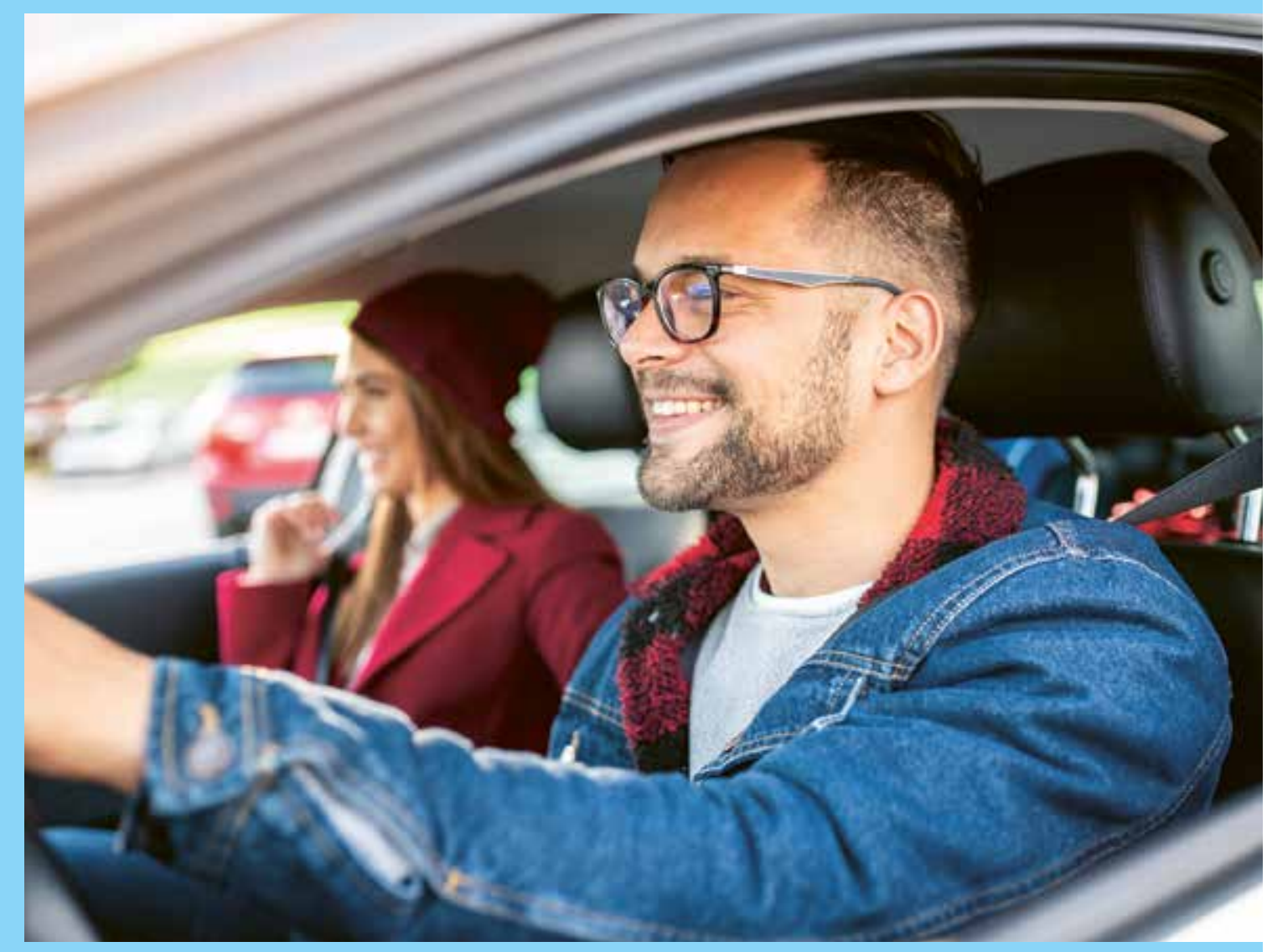

Bestudering van wat zoal besproken wordt tijdens de autoritjes van en naar de PLGbijeenkomsten geeft inzicht in wat wel en niet werkt. Die besprekingen bestaan uit: Mijmeren op de heenreis, wat bijpraten over wat er tot vlak voor het instappen op je school is gebeurd, opborrelen van dingen die misschien wel interessant kunnen zijn en warempel ook best passen in het thema. Reflectie tijdens de terugreis. Overwegen wat je misschien morgen al kunt gebruiken plus wat er verder opkomt in de steeds vertrouwder wordende setting. De verhalen hieronder zijn gebaseerd op wat die docenten tijdens een van de vele PLG's aan elkaar hebben verteld. Ze zijn toegespitst op ons thema: de Professionele Leergemeenschap.

1. Onderweg naar de eerste bijeenkomst met collega-docenten van zes andere scholen

Collega 1 (C.1) zit naast collega 2 in de auto en wordt in gedachten heen en weer geslingerd tussen twijfel en hoop. Gaat dit wat worden? Het heet een 'Professionele Leergemeenschap'. Hoe saai wil je een naam hebben?

Oh nee, laat ik nou niet. .

Oh ja, laat ik het een kans geven.

Maar wat voor kans. Wat wil ik eigenlijk?

Kijk, dat is lastig om over te hebben. Ik hoor het gewoon te weten.

ledere docent moet alles weten.

De leerlingen vragen van alles, en het is vanzelfsprekend dat ik daar dan een antwoord op kan geven.

De ouders vragen van alles en daar moet ik dan ook de antwoorden op weten.

Idem dito met de collega's. En thuis gaat dat net zo. Ik ga me ernaar gedragen. Ik moet alles weten.

Collega 2 (C.2) "Wat vind jij eigenlijk van die PLG?"

C.1. (De vraag van m'n collega haalt me uit m'n mijmeringen). Mijn antwoord luidt: "Ik weet het nog niet."

C.2. "Ik eigenlijk ook nog niet."

We schieten in de lach. Heerlijk om het gewoon samen niet te weten. Heel anders dan we gewend zijn in ons dagelijks werk.

2. De terugweg na de eerste bijeenkomst

We zitten wat stil naast elkaar. Zoveel indrukken, en ik zeg:

C.1. Wat grappig dat die begeleiders nu bij elkaar zitten om hun eigen eerste indrukken aan elkaar te vertellen en dat ze dat opnemen. Hoe noemen ze dat nou? Oh ja, 'bloed, zweet en tranen'.

C.2. Ja, het was even wennen. Al die mensen... ledereen was er trouwens, en ik heb het idee dat iedereen er de volgende keer ook weer bij zal zijn.

Die begeleiders, hoe noemen ze zich ook alweer?

C.1. 'Facilitators', zeg ik.

C.2. Oh ja, facilitators. Ze doen eigenlijk niet zoveel (lachje). Ze zijn vooral druk met ons aan het werk te krijgen. We lijken soms wel van die onwillige leerlingen (we lachen allebei). Ja bizar hè, hoe we ons soms gedragen.

C.1. Wat ik nu wel weer heel helder heb gevoeld, is dat we zelf de professionals zijn die samen zoveel mogelijk met en van elkaar willen leren. Dat is logisch, dat weet je wel, maar in het 
dagelijks gebeuren vergeet ik dat geregeld en ga ik me gedragen op een manier die ik, meestal achteraf gezien, niet wil. Als ik me daarvan gewoon de hele dag bewust kan zijn, zou me dat zoveel opleveren in het contact met de collega's en zeker ook met de leerlingen. C.2. Wat een verzuchting (lachje). Maar ik ben het helemaal met je eens hoor. Als dat het resultaat van deze PLG-bijeenkomsten gaat worden, zijn ze nu al geslaagd! En het gaat meer opleveren. Wat vond jij bijvoorbeeld van die collega met z'n filmpje, over het uitzetten van een tuintje. Daar zat uitleg in over wat vaardigheden. Zo helder. Lijkt me leuk om te maken en handig voor leerlingen om nog een paar keer te zien.

Hij vroeg ons om reactie. Wat waren we voorzichtig daarin. Toen was hij heel duidelijk en zei dat hij gewoon een concrete reactie wil. Hij wéét wel dat het niet afbrekend bedoeld wordt door ons. Hij wil het graag horen en, als hij het als een verbetering ervaart, het erin verwerken en ons de volgende keer het verschil laten zien. Heerlijk zo'n man met zoveel plezier in wat hij doet.

C.1. Oh ja, dat vond ik ook wel een mooi moment. De begeleiders lieten dat gewoon lopen en kwamen er direct daarna op terug: hoe ons gesprek ging, wat we erbij voelden, welke wendingen we namen en welke afslagen ook hadden gekund. Waarom we het deden zoals we het deden. Geen gedoe. Praktisch en direct bruikbaar in onze eigen gesprekken met collega's en leerlingen.

$[\ldots$ weer even stil, samen in de auto... $]$

C.1. Wat ga jij, tussen nu en de volgende PLG-bijeenkomst, met digitaal onderwijs doen op school?

C.2. Ik zit al wat te denken over wat jij op de heenweg vertelde over filmpjes die de leerlingen zelf maken en presenteerden. Daar zit voor mij al zoveel in over wat ze als leerling-groep aan elkaar dingen gaan leren, zoals downloaden van bijvoorbeeld Movie Maker: hoe het te gebruiken, hoe stukjes invoegen, tekst en muziek eronder, enzovoort. Dat ze er trots op zijn op dat ze elkaar dingen kunnen leren en kunnen laten zien en aan elkaar presenteren. Dat levert zoveel leermomenten en resultaten op, die ook weer op heel andere plekken bruikbaar zijn. En dan is het aan mij om geregeld momenten te vinden om er met hen op te reflecteren. Oh ja, dat woord 'plezier' kwam vandaag ook geregeld langs als heel bruikbaar. Daar moet ik ook nog eens goed over nadenken. En kunnen wij elkaar dan tussendoor af en toe zien en even doorpraten over onze PLG-acties?

C.1. Dat klinkt heel energiek. En ja, fijn om elkaar bijvoorbeeld iedere week te zien en bij te praten.

Eigenlijk wil ik wel gaan uitvoeren wat jij op de heenweg hebt verteld. Ik kreeg daar al het beeld bij van een leerling die al dagen niet op school is geweest en door niemand gebeld. En dan met hele groep een paar filmische scenario's uitwerken van wat de reden van afwezigheid kan zijn en wat er gebeurd (kan zijn) in de drie dagen dat de leerling niet op school was.

Bijvoorbeeld twee hele leuke: opgehaald door een filmploeg voor een verrassende reis of een of andere romantische plot die ze zelf verzinnen. En twee versies waarin de leerling gewoon ziek is en ze vergeten zijn om dat op school te melden. Ik weet het nog niet... Wordt de komende dagen vast wel helderder.

Leuk dat we ook nog een samenvatting krijgen van wat hebben afgesproken. Dat doen die facilitators dan toch wel.

C.2. Ja, mooi hoe we het digitale overal kunnen gebruiken, wat voor inhoud het ook betreft Oh, ik heb je nog helemaal niet verteld hoe het nu bij mij werkt aan het begin van de lessen. Dat heeft nog een hoop teweeggebracht. Vertel ik je graag binnenkort wat uitgebreider.

Oké, we zijn weer op school. Ik spring op de fiets. Tot morgen!

\section{Op weg naar de tweede PLG-bijeenkomst}

[Twee collega's, nu van een andere school]

Collega 1. Het verslag van de vorige keer heb ik uitgeprint en naast m'n beeldscherm gehangen zeg maar als een soort intentie. En verder ben ik de hele maand opgeslokt door de lessen en teamzaken. Ik ben blij dat we in ieder geval nu samen onderweg zijn. Dat had ook weinig gescheeld... (zucht)

Collega 2. Ja, ik ben ook blij dat we onderweg zijn. De herinneringen aan de vorige keer zijn goed. Dit hadden de facilitators aan het einde ook gezegd. Het kan zijn dat je over een maand hiernaartoe rijdt en denkt: Wat is wel gelukt en wat kan de volgende keer beter? En ook: Wat heb je daarvoor nodig... Wat denk jij?

C.1. Wat bedoel je?

C.2. Nou wat ze zeiden: wat is er wel gelukt, wat kan beter en wat heb je daarvoor nodig? C.1. Heb je even? Er is niks gelukt en het kan dus heel veel beter. Maar geen geklaag, want ik ben er zelf ook bij.

C.2. Klagen? Doen we in de lerarenkamer, geintje! Maar even serieus: ik heb twee dagen later in mijn team kort verslag gedaan van de eerste PLG-bijeenkomst en heb ze verteld dat ons doel is om als professionals met elkaar te leren. Daarom heet het een 'Professionele

Leergemeenschap'. We wisselen kennis en ervaring uit, we kijken wat we samen kunnen uitvinden of ontwikkelen. We proberen of het ontwikkelde materiaal ook werkt in onze lessen. Dat bespreken we met elkaar en we helpen elkaar om het verder te verbeteren. Zo ongeveer heb ik het verteld.

C.1. En?

C.2. Nou, ik weet niet hoe het bij jullie is, maar bij ons is er eigenlijk altijd haast. Bij ieder punt haast. Logisch hoor, want er is een hoop te bespreken, maar als ik er nu op terugkijk ... Er werd eigenlijk niet echt op ingegaan.

C.1. Misschien is dat wel de reden waarom ik het niet eens gemeld heb in het team. Een soort zelfbescherming tegen teleurstelling.

C.2. Maar ik vond de eerste bijeenkomst gewoon heel goed en inspirerend. En dat wil ik niet laten verdwijnen door de drukte in het dagelijks werk op school. Hoe zouden onze PLG-

collega's dat op hun school doen?

C.1. Top! Zullen we straks ons gesprek, als toneelstukje, overdoen voor de hele PLG-groep? Misschien iets vooraf zeggen, bijvoorbeeld: we willen het komende stukje van twee minuten graag met jullie bespreken aan de hand van de punten:

-Wat is herkenbaar?

- Wat zijn de stappen die je kunt zetten om het in beweging te krijgen?

- Wat is nodig om het geregeld op de agenda te krijgen van o.a. het teamoverleg? De intentie is om zicht te krijgen op hoe het wel kan.

C.2. Klinkt goed. Weet je wat ik nou zo mooi vind? We hebben die hele groep mensen pas één keer gezien, en nu heb ik al het gevoel dit met hen te kunnen doen en bespreken.

C.1. Mee eens, doen we! Bijzonder... (peinzend), wat zou daar het geheim van zijn? Oké, we stellen het gelijk voor aan de facilitators. Jij rijdt. Zal ik één van hen bellen?

Samenvatting van telefoongesprek: "Goed plan. Kan zeker in het programma voor vandaag. Graag opnemen. Privacy gegarandeerd. Als hele groep het goed vindt, ook het vervolggesprek opnemen."]

C.2. Dat voelt goed maar maakt ook wel een beetje zenuwachtig. We kunnen nou niet meer terug. Help!

Stilte in de auto...

C.2. Wat nu? Moeten we er nog meer aan voorbereiden? Wat denk jii? 
C.1. Weet je, wat we net zeiden kwam zo spontaan op. Dat was helder en lekker kort. De rest komt wel in het nagesprek. Nog even herhalen hoe we net zijn begonnen en dan stoppen we erover, oké?

C.2. Oké.

\section{De terugweg}

C.2. Wat een dag! Poeh, en heerlijk. Wat komt er veel langs waar je direct wat aan kunt hebben. Geweldig hoe die collega het filmpje van vorige week liet zien en daarna het nieuwe filmpje dat hij had aangepast na onze vragen, opmerkingen en tips. Zoiets kan ik nog lang niet, en ik weet ook nog niet waar dat voor mijn lessen effectief kan zijn.

C.1. En hoe hij zichtbaar blij is met onze inbreng. Wat ik zo grappig vind: hij zegt hoeveel plezier hij er in heeft om dit te maken en te gebruiken. Vervolgens, haast als excuus, dat hij daardoor alle technische dingen er haast terloops bijgeleerd heeft. Dat hij wel begrijpt dat wij dat allemaal minder paraat hebben dan hij. Dat hij ons best een keer een soort technischeknoppencursus wil geven. Nou, dat lijkt me wel wat.

En even wat anders: gefeliciteerd met je toneeloptreden. Je hebt me echt geholpen om erbij te blijven.

C.2. Graag gedaan. Je moest even op gang komen. Ik was ook zenuwachtig. Daarna ging het toch prima? Wat ging het inhoudelijk goed hè. Eigenlijk alleen maar opbouwend naar 'Wat kan er wel?'.

En wat hebben de facilitators daar een goeie rol in. Voor mijn gevoel ging het snel over wensen, verwachtingen en redenen om deel te nemen, zowel van de docent als de teamleiding. Ook kwam aan de orde hoe je er als school voor kunt zorgen dat de PLG-deelnemers de juiste professionele ruimte krijgen om eraan mee te doen. Ja, dat woord 'PLG' krijgt voor mij meer betekenis.

C.1. Wat voor mij al wel wat ver ging, is hoe een PLG kan bijdragen aan de schoolontwikkeling. Wat ik me kan voorstellen is dat de schoolleiding deze PLG gebruikt om meer docenten enthousiast te krijgen voor deelname aan een PLG. En dat je van tevoren helder afspreekt op welke manier de ontwikkelingen in een PLG gedeeld worden met de collega's. Zoiets? C.2. Misschien moeten wij, samen of ieder afzonderlijk, een gesprek hebben met onze teamleiders. We kunnen hun dan vragen wat hun wensen zijn m.b.t. de PLG en vertellen wat onze ervaringen en wensen zijn. En dan kunnen we samen kijken hoe de school er zoveel mogelijk aan kan hebben.

C.1. Sorry dat ik even wat somber reageer. Ik sta er helemaal achter hoor. Alleen, het lukte me de vorige maand al niet om er ruimte voor te maken. Hoe ga ik dat nu doen? Het vliegt me ineens naar de keel.

C.2. Ja, balen is dat gevoel. Misschien moeten we ons toneelstukje nog een keer doen, samen met de teamleiders. En dan weer met dezelfde vraag: 'Wat kan er wel en hoe kan het wel?'

Als we dat zo doen dat ze zich niet gelijk aangevallen voelen en denken dat ze ons extra uren moeten geven...

C.1. Ja, graag opbouwend. Maar aan het eind van ons gesprek wil ik mijn eigen teamleider wel vragen hoe we de extra PLG-inzet zichtbaar kunnen maken in mijn urenverantwoording. Weet je, ik sta voor 32 uur op de loonlijst. Kan iedere week makkelijk 40 uur zichtbaar maken in de urenverantwoording, maar die krijg ik dan terug met de vraag om hem aan te passen. Dat werkt demotiverend. Dus dat gesprek moet ik gewoon aangaan. Natuurlijk kan ik vinden dat de teamleider dat initiatief moet nemen, maar ik zit ermee, dus laat ik het zelf maar doen.Pfff.. C.2. Wij zien elkaar morgenmiddag. Gooi me er hier maar uit. Ik ben thuis. Bedankt.

\section{Op weg naar de derde PLG-bijeenkomst}

[Twee collega's van weer een andere school. Zij zitten wel samen in hetzelfde team. C.1 rijdt en heeft er zin in. Ze heeft een vrolijk muziekje opgezet.]

C.2. Nog even en we gaan meezingen.

C.1. Weet je, zelfs zo'n dagje PLG kan een beetje als een schoolreisje voelen. Gezellig met jou op pad, gezellige collega's... We hebben het over dingen die morgen weer bruikbaar zijn, nou ja zo nog van alles. Ik heb er wel plezier in.

C.2. Wat ben je toch een heerlijke optimist

C.1. Optimist? Realist zal je bedoelen. Dit hebben we gewoon nodig. lk rijd al bijna tien jaar met $m^{\prime} n$ broodtrommeltje naar deze school en ik vind het echt leuk hoor om met die kinderen aan de slag te zijn. Maar vmbo vraagt ook veel van me. Dus die scholing en cursussen

tussendoor helpen me om wakker te blijven en er plezier in te houden. Het zou toch te gek zijn dat alleen de leerlingen bij ons leren en wij een beetje blijven teren op een opleiding van jaren terug. Kom op zeg, hoe heet dat, 'education permanente' toch?

C.2. Helemaal mee eens. Bij deze bijeenkomsten heb ik nog een extra gevoel. We zoeken samen naar iets waar we direct wat aan hebben in onze lessen. En we kijken of onze eigen school er iets mee zou kunnen doen. Of dat allemaal gaat uitkomen, zien we nog wel. We hebben tien bijeenkomsten dus we kunnen nog van alles in beweging zien te krijgen in onze leercultuur.

C.1. Ben ik toch de realist en jij de optimist of misschien wel de dromer?

C.2. Hoezo?

C.1. Nou ik heb je net gezegd hoe ik me een realist vind. Jij haalt er dingen bij die beleidsmakers zeggen en in rapporten staan. Over in beweging zien te krijgen en kijken of onze school er iets mee zou kunnen doen, leercultuur. Dat hoor en lees ik vaker, maar ik zie het weinig in het concrete werk terug.

C.2. Geinig. Nou klink je voor mij als een pessimist.

C.1. Volgens mij blijf ik de realist, gewoon omdat wat ik zeg ook echt gebeurt. Ik ben er op tijd even tussenuit met een goeie cursus. Heb daar plezier in en kan daardoor, ook met plezie door met m'n lessen. En wat jij nu noemt, is weinig zichtbaar in het dagelijks gebeuren op school.

C.2. Misschien heb je gelijk, maar ik zou het wel anders willen. Wat jij doet, vind ik geweldig, en dat merk ik ook in het team. Op de één of andere manier kan jij het zo. En weet je, ik denk dat een heleboel collega's dat ook zo zouden willen kunnen. Misschien moet jij maar een PLG gaan geven over 'Hoe houd ik me met plezier staande in de dagelijkse chaos van de school'. Echt, petje af voor hoe je dat doet.

C.1. Dankjewel voor het compliment en leuk dat je het zo ervaart. Dat beeld wat je schetst is zeker mijn streven. Maar het is ook geregeld een klus om het voor elkaar te krijgen. En - dat is wel belangrijk - ik voel goed aan wanneer ik een beetje gas terug moet nemen en welke cursus $\mathrm{ik}$ tussendoor moet doen. Dat houdt me echt op de been en houdt het plezier erin.

C.2. Nog even over wat ik wel anders zou willen: dat we als docenten concreet dingen afspreken over wat we ons wensen aan ontwikkelingen en hoe we daar samen aan kunnen werken. Een beetje zoals we dat in deze PLG aan het ontwikkelen zijn. We kunnen toch kijken wat we samen willen en wat het eerste stapje is dat we samen in die richting kunnen zetten? Dat lijkt me zo lekker praktisch en stimulerend voor ons teamgevoel. Je ziet en ervaart dan resultaten. Kortom, plezierig voor iedereen. 


\section{De vierde PLG-dag: de heenri}

C.1. Goeie morgen, fijn dat je me op komt halen. Pfff, ik zit..

C.2. Ook goede morgen, heb je wel een beetje zin?

C.1. Helemaal niet. Als jij niet gekomen was, was ik niet gegaan.

C.2. Wouw, dat is al drie keer niet. Wat vervelend voor je en stoer dat je toch samen wilt gaan.

C.1. Ja, dat heet 'solidair' hè. Dus ik ga niet zitten sacherijnen hoor, maar het moet me wel even van het hart.

C.2. Nou, stort je hart maar uit, ten minste als je er nu vanaf wilt en als je dat bij mij wilt doen. C.1. Ik ben in zo'n stemming dat het er gewoon uit moet.

C.2. Ik heb koffie voor ons meegenomen. Dan hier ons eerste kopje?

C.1. Liever maar gewoon rijden als je dat goed vindt ... Weet je, ik werd ermee wakker.

Gelukkig wel goed geslapen. De teamleider wilde gisteren dat ik vandaag op school zou zijn voor ziektevervanging. Ik hoorde de vraag en werd een beetje misselijk. Bijna viel ik boos uit en toen moest ik denken aan de vorige PLG. Toen iemand van een andere school ook zoiets vertelde en hoe we het daar met elkaar over hebben gehad. Dat was m'n redding. Ik vroeg wanneer ze even tijd had en dat ik dan terug zou komen om het te bespreken. Haar reactie was: maar ik moet het nu regelen. Ik voelde me koken van binnen en kon er nog net uitbrengen: oké, ik ga even naar het toilet en kom terug met een kopje koffie en dan hebben we het erover. Wat wil je er ook alweer in? Ik zat bijna te huilen op het toilet; voelde me zo beroerd. Ze is m'n teamleider, echt een goed mens, maar dan zo hard - "lk moet het nu regelen - en niks over mijn studiedag en de PLG. Hoe werd dat ook weer genoemd de vorige keer:

soort houding van de gestreste manager die in het nauw zit en daarmee in feite het hele team infecteert. Nou ja, daar zat ik dan op dat toilet. En ik wilde vandaag gewoon met jou naar onze PLG, maar wist nog niet hoe dat zou gaan lukken. Man, dat is zo'n vervelend gevoel. Dat je ergens graag naartoe wilt, dat het goed is voor mezelf, voor m'n werk met m'n collega's en zeker ook met de kinderen. En dat m'n leidinggevende ... I k kwam er niet uit.

[stilte]

C.2. En nu zitten we toch samen in de auto.

C.1. Ja dat wel, maar ik heb er geen goed gevoel over. Ze snapte het wel, maar was het er eigenlijk niet mee eens. En ik snap haar ook wel, maar ik wil dat ze me gewoon steunt en me nu niet met het gevoel laat gaan dat ik haar eigenlijk met een probleem heb laten zitten. Dat is geen manier van leidinggeven. Maar ik heb het ook niet goed gedaan. Dus ik zit hier gewoon te balen. Het liefst wou ik dat ik nooit aan die PLG was begonnen ... Wat doe je nou? C.2. Even naar die parkeerplaats. Ik heb de tranen in m'n ogen en wil een kop koffie.

[... diverse uitspraken die niet door de censuur kwamen (samen lachen, samen huilen), en na de koffie weer samen verder op weg.]

C.1. Poeh, dat lucht op. Dankjewel dat je wilde luisteren. Nog even en je gaat voorstellen dat wij dit keer wel kunnen vertellen over onze autorit, net als vorige week die andere twee. C.2. Zou je dat durven? Ik vind je verhaal wel erg persoonlijk.

C.1. Ik ben bang dat het helemaal niet zo persoonlijk is.

\section{De terugrit vanaf de vierde PLG-bijeenkomst}

C.1. Wat was ik blij met die praktische les van onze 'film-collega'. Dat gaat me zoveel helpen bij het digitale deel dat ik wil gebruiken en doen. Al die dingen als uploaden, downloaden, opzoeken, knippen, plakken, foto's bewerken, films opnemen en bewerken - de hele 'knoppen-cursus'. Hij maakte het zo toegankelijk.
C.2. Ja, daar kan ieder van ons een hoop aan hebben. Trouwens wat reageerde hij mooi op jouw verhaal. Zo ongeveer: "Dat wat ik jullie heb verteld, is voor mij heel makkelijk, en het is fijn dat jullie er zo positief op reageren, maar wat jij ons hebt verteld, dat vind ik zo indrukwekkend. Dat zou ik echt zo moeilijk vinden. Fijn dat je het gedaan hebt en ook zo herkenbaar voor mijzelf. Dankjewel." En die reactie kreeg je eigenlijk van iedereen wel. ledereen herkende wel de momenten in de eigen teams, dat in de dagelijkse druk en drukte van het schoolwerk geregeld een heleboel klem komt te zitten. En ieder herkende op z'n eigen manier wel hoe je daar last van kunt hebben en hoe de communicatie daarover soms als beroerd ervaren wordt. C.1. Ja, mooi dat werd voorgesteld om daar de volgende keer verder op in te gaan en te kijken hoe we dat constructief kunnen gebruiken. Hoe zei één van de facilitators dat ook weer? lets uit dat boekje spinsels in je hoofd, beren op de weg... Oh ja: "Wat is helpend en wat is niet helpend en hoe kan je jezelf en je gesprekspartner helpen om steeds te kiezen voor de voortzetting waarmee je elkaar, en dus het onderwerp waar je het over hebt, vooruithelpt?" C.2. Wel een kunst, hoor, om steeds zo bewust te zijn van al de mogelijkheden en ze dan op het juiste moment voorhanden te hebben. Dat vind ik met de leerlingen al een klus, en als dat dan ook nog eens zo alert met m'n collega's moet, dan is alles netwerken... Geintje! C.1. Nee joh, we hebben ook gewoon pauze en dan kun je gewoon een beetje dollen met elkaar. Tenminste als we niet als stresskippen naast elkaar zitten ... Gossie, geeuw, misschien kunnen we in het teamoverleg een paar momentjes hebben die lijken op wat we in de PLG doen. Is vast verfrissend voor ons samen.

C.2. Hoe krijgen we de PLG het team in?

C.1. Goed plan. Gaan we het over hebben. Maar nu een goed muziekje!

\section{Autorit naar zevende PLG-bijeenkomst}

C.1. Er is gisteren iets gebeurd ... Het voelt wel goed en ook alsof ik gesprongen ben en nog niet weet waar en hoe de landing zal worden.

C.2. Goedemorgen, lekkere binnenkomer! Laat me raden: je hebt een sprookje gelezen of verteld.

C.1. [verbaasd] Hoe weet jij dat?

C.2. [nog verbaasder] lk weet niks, hoezo?

C.1. Oh, het kon zijn dat het al via de school-tamtam bekend was geworden.

C.2. Nu maak je me echt nieuwsgierig. Vertel!

C.1. Oké, al zal je me af en toe misschien wat moeten helpen. Het heeft namelijk te maken met wat jij vertelde tijdens onze eerste rit naar de PLG.

C.2. Wat?

C.1. Ja, zo zie je maar wat een invloed je hebt. Wie zong dat ook weer van die steen in de rivier en de stroom zal nooit meer dezelfde zijn?

C.2. Zoeken we op. Maar vertel, want ik word steeds nieuwsgieriger.

C.1. Je vertelde destijds over samen met de leerlingen kijken en registreren wie er aanwezig is en wie niet, en waarom, enz. En over jouw collega die vertelde wat ze daaraan had. Ze zei ongeveer: "Dat samen registreren duurt nu nog maximaal 5 minuten en iedereen is vanaf het begin betrokken en dus aanwezig." Ze ervoer het als groot voordeel dat ze daardoor met alle leerlingen aan de door haar voorbereidde les kon beginnen. Ze noemde dat de eerste winst. C.2. Dat herinner ik me en het blijft voor mij goed werken. En voor jou? C.1. Weet je, ik ben er, eh ... , op mijn manier, met één groep, mee begonnen, nog vanuit dat gevoel van: dit moet er ook weer bij en ik heb het al zo druk ... Je weet wel die dominante dingen, gedachten, of misschien wel beperkende overtuigingen waarvan het lijkt dat we daar 
collectief last van hebben. Het liep stroef, dus ik was er na twee keer bijna mee gestopt. Tijdens de derde keer zei een leerling tegen me, waar alle leerlingen bijzaten, dat het voor haar goed werkte. Dat ze haar vader had gevraagd om naar school te bellen toen ze echt ziek was en dat haar vader zo blij had gereageerd op hoe de telefoniste hem te woord had gestaan en dat hij, namens de telefoniste, haar - die leerling dus - beterschap moest wensen. Je had ze moeten zien en horen. De positieve verhalen rolden over elkaar heen.

C.2. Wat goed!

C.1. Ik heb het een beetje aangehoord en toen kwam de vraag waarom niet alle docenten dit doen aan het begin van de dag. En iemand anders riep nog: "En aan het begin van de middag!" C.2. En jij dacht dat ik dit al via de tamtam had meegekregen?

C.1. Nee, dat is nog heel wat anders.

C.2. Je maakt het wel heel spannend. Ik vind het nu al zo'n geweldig verhaal.

C.1. Oh ja, hoe het verder ging. Je weet dat ik ook een paar uur heb als zorgdocent in ons team. Ik liep tussendoor wat te sudderen op wat de leerlingen me allemaal hadden meegegeven. En verdraaid: twee weken geleden kwam er één op terug. Die riep gewoon: "lk ben wel benieuwd wat u heeft gedaan met onze vraag voor uw collega's ..." Je begrijpt, de echo kwam: "Ja, wij ook." Daar zat ik met m'n goede gedrag. Ik zei eerlijk dat ik er nog niet uit was. Zei er één: "Dat is toch niet zo moeilijk?" En weer de echo: "Ja, dat is helemaal niet zo moeilijk hoor juf."

"Ik zal er echt eerlijk op terugkomen."

De klas: "Beloofd?"

Ik: "Beloofd."

C.2. Hoe krijg je het voor elkaar!

C.1. Ik vroeg hen dus hoe ze denken dat mijn collega's gaan reageren als ik dat voorstel. "Nou gewoon," zeiden ze., "u zegt wat u doet en dat het werkt. En dan gaan zij het ook doen." Toen vroeg ik aan de leerlingen: "Help me nog even: wat vinden jullie dat goed werkt aan het begin van ons lesuur?"

"Nou," zeiden ze, "wie er aan- en afwezig is weten we binnen een minuut en waar de meeste afwezigen zijn ook. Dan blijft er misschien één over, en daar belt de leerling-administratie achteraan."

"En dan nog een keer jullie hulp: waarmee haal ik dan mijn collega's over de streep?"

En toen werd het stil. Een meisje begon te huilen. Het leek alsof de meesten wisten waarom.

En ik, zorgdocent, wat wist ik? Ik voelde me door het ijs zakken. Dacht: help PLG-collega's, hoe zat dat ook weer? Open, rustig met betrokkenheid, maar wel stevig. En omdat ik niks zei,

kwam ze zelf met: "Juf, ik heb iets meegemaakt dat voorkomen had kunnen worden ... denk ik, met ons begin van de les." Ik voelde me nog verder wegzakken. Oh nee, dacht ik ... "Nou ja," zei ze, "een soort vriendin van me op een andere school." Ik voelde me een beetje tollen en het schoot door me heen: wat maken die kinderen toch een hoop mee waar wij helemaal geen weet van hebben... In het kort kwam het erop neer dat die vriendin in de klauwen was gevallen van een loverboy, en volgens de leerlingen had eerder in beeld moeten komen dat er iets niet klopte.

C.2. Nee, wat een pijnlijk en ook helder verhaal.

C.1. Helaas ja. En dit komt vaker voor. Het is allemaal nogal vers wat ik je nu vertel.

C.2. Jeetje!

C.1. Die vriendin heeft nu goede hulp, maar de klas was ontdaan. En weet je: hoe verdrietig ook, dit zijn de momenten waarop je met hen kan praten over wat er in hun wereld gebeurt, hoe ze zich erbij voelen en hoe ze ermee zouden kunnen omgaan, hoe ze het kunnen herkennen en elkaar kunnen helpen om dingen anders te laten gaan. Dus ... laten we het maar hebben over wat er schuurt en hoe het pijn doet, over wat je vrienden, je ouders, verdere familie en zeker ook de school eraan zouden kunnen doen.
En ineens was het weer genoeg. Het is net alsof er een golf is waar ze samen op zitten. En dan is ineens de aandacht weg.

Dus ik vroeg. "Mag ik jouw voorbeeld anoniem gebruiken bij mijn collega's?" En dat mocht. k bedankte haar en de hele groep, en zei dat ik het voelde als een zwart sprookje, wat helaas kan voorkomen, en dat we samen moeten proberen om het leven vrolijker te houden en dit soort dingen helpen voorkomen.

lk had dat woord 'sprookje' gebruikt, dus dacht dat je dat daarom aan me vroeg toen ik in de auto stapte.

C.2. Dat was toevallig. Dankjewel voor je verhaal. Wat verdrietig dat dit soort dingen gebeuren en wat geweldig dat dit eenvoudige systeem van consequente aanwezigheidsregistratie, en actie daarop, kan bijdragen om dingen te bespreken. C.1. Ja, en dat je dit soort dingen er ook, misschien af en toe, mee kunt voorkomen. C.2. En nu?

C.1. Ik heb de leerlingen iets toegezegd en ik heb toestemming om het voorbeeld anoniem te gebruiken. Je kunt zeggen, ik zit helemaal klem. Je kunt ook zeggen ... ja, wat eigenlijk ...? lk weet het gewoon nog niet. Volgende week hebben we teamoverleg. Twee dagen later heb ik deze groep leerlingen weer. Ik maak best geregeld bijzondere omstandigheden mee. Deze

hoort wel in de top-10. Ik wil hem zo goed mogelijk benutten, maar heb nog niet helder hoe en in welke richting.

C.2. Wat denk je, kunnen we dit inbrengen in de PLG?

C.1. Fijn dat je dat vraagt.

C.2. Tuurlijk, en weet je: het is in zoveel opzichten van belang. ledereen heeft hier, op wat voor manier dan ook, wel mee te maken. Dus ja, inhoudelijk, sociaal, maatschappelijk, 100\% inbrengen! En om het dan toch even aan het digitale thema van onze PLG te linken: als iedere docent dit inhoudelijk tot op de botten voelt, is de wens om er zelf wat aan te doen er helemaal. En als jij en ik, en natuurlijk ook anderen, aangeven hoe het werkt en wat het, zonder echte problemen, al aan extra's oplevert in het dagelijks gesprek met de leerlingen, dan helpt onze digitale registratie zeker. Voorwaarde is dat we consequent zijn per klas, per locatie, iedere dag op de afgesproken tijden.

En dat we laten zien hoe de inzet van het digitale ons helpt bij het contact met de leerlingen over veel meer dan aan- en afwezigheid. Dat deel kan ik wel aardig toelichten vanuit m'n eigen praktijk.

C.1. Oké, we brengen het in, in het eerste rondje. Vooraf even met een facilitator bespreken? Wat ik ook graag wil bespreken is hoe we het in de PLG onze werkwijze behouden. Er is een redelijke kans dat we met dit verhaal in een soort intervisiebijeenkomst terechtkomen. C.1. Vind je het goed dat we nu wat lichters gaan doen? Of kom jij nu helemaal niet aan je trekken?

C.2. Ik kom helemaal aan m'n trekken. Er is geen brand, en weet je: dankjewel dat je dit verhaal ook zo koppelde aan ons gesprek tijdens de eerste autorit naar de PLG. Mooi hoe zo de lijn loopt vanaf die collega van een andere school naar deze ontwikkeling.

Dat is wel een vraag die ik bij zoiets heb: hoe komen we vanuit incidenten tot inhoudelijk beleid en hoe houden we dat als school samen levendig en in ontwikkeling?

Maar goed, dit is genoeg voor onze PLG-bijeenkomst.

Oh ja, die muziek van iemand over een steen in de rivier, kun jij die even opzoeken op Spotify? 


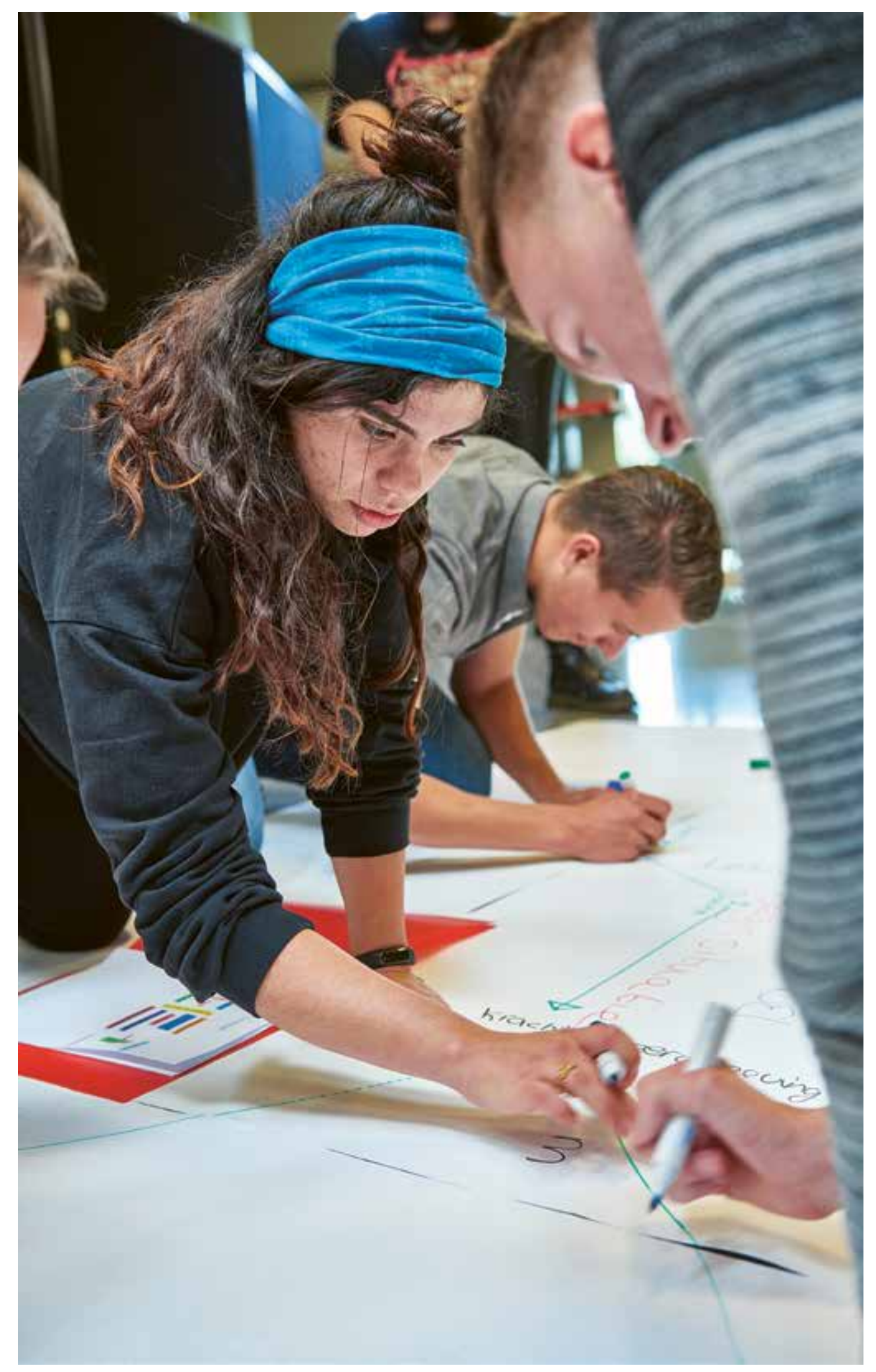

9. Laatste heenreis naar de tiende PLG-bijeenkomst

C.1. Dit is voor mij zo lastig. Er zijn zoveel gevoelens die even voorrang vragen. Ik lijk wel een jongleur.

C.2. [zit zachtjes te grinniken]

C.1. Ja, lach jij maar. Ik heb het ermee te doen.

C.2. Ja, en ik heb met jou te doen. Partir c'est mourir un peu.

C.1. Fijn dat je begrip toont. Maar weet je, als je het niet kent, voel je niet echt hoe diep dat kan gaan en hoe je ervan in de war kunt zijn.

C.2. Dat geloof ik direct. Vertel, tenminste als je wilt.

C.1. Nou, ik ben blij dat het de laatste keer is. Tien keer was prima, maar nu is het even genoeg. Tegelijkertijd ga ik iedereen nu al missen. Veel geleerd en gedaan en nog best veel te leren met deze groep. Heb twijfel of het wel wijs is om te stoppen. Kunnen we na de vakantie niet nog een jaar door?

C.2. Blij dat je het me zo helder vertelt.

C.1. Misschien klinkt het helder, maar ik heb het nog niet helder. Het voelt een beetje alsof ik alles wil hebben. Ik wil graag vrij hebben maar wel aan de PLG blijven meedoen. Ik wil tijd hebben om andere dingen te doen en wil dit tegelijkertijd ook graag blijven doen. Dan voel ik me wel eens onzeker worden, omdat niet alles kan en ik moet kiezen.

C.2. Ik wil niet met oplossingen komen, hoor. Maar wel vraag ik me af van wie je moet kiezen. C.1. Nou, het kan gewoon niet allemaal tegelijkertijd.

C.2. Tegelijkertijd?

C.1. Ach, weet ik veel. Ik kan dit gewoon slecht. Afscheid nemen van een groep waar ik me zo prettig in voel. We hebben zoveel dingen samen gedaan, samen bereikt, en ik kan er gewoon een hoop mee in m'n werk. Het geeft me plezier, geeft me kwaliteit in m'n werk, geeft

resultaat en - vooral - geeft me geregeld lucht. Wie zei dat ook weer: "Adem en aandacht: de leerlingen en ik floreren daar het best op."

C.2. Zal ik je mijn gevoel hierover eens proberen te beschrijven?

C.1. Nou?

C.2. De PLG is hooguit één dag in de maand. Ik mag er in m'n eigen, betaalde studietijd even tussenuit. Ik kom steeds weer thuis met iets waar ik wat mee kan doen. Ik heb met collega's en professionals de tijd vrijgemaakt om het over de inhoud en interessante mogelijkheden te hebben.

We hebben samen kunnen werken, oefenen, en het daarna in de praktijk kunnen brengen. We hebben als collega's elkaar feedback kunnen geven en ontvangen. Voor mij is het echt zinvol werken en plezier met vakgenoten hebben.

Weet je, nu ik dit zo tegen je zeg, denk ik: dit wordt voor mij het nieuwe normaal! C.1. Dankjewel. Dit had ik nodig. Zullen we volgend jaar weer samen met een groep collega's aan de slag gaan? 


\section{Hoofdstuk 5}

\section{Onderzoek naar PLG's:}

pilots voor de ontwikkeling

van professionele

leergemeenschappen 6

"Ik leer iedere keer nieuwe en heel verschillende

\section{dingen en kan ze direct toepassen."7}

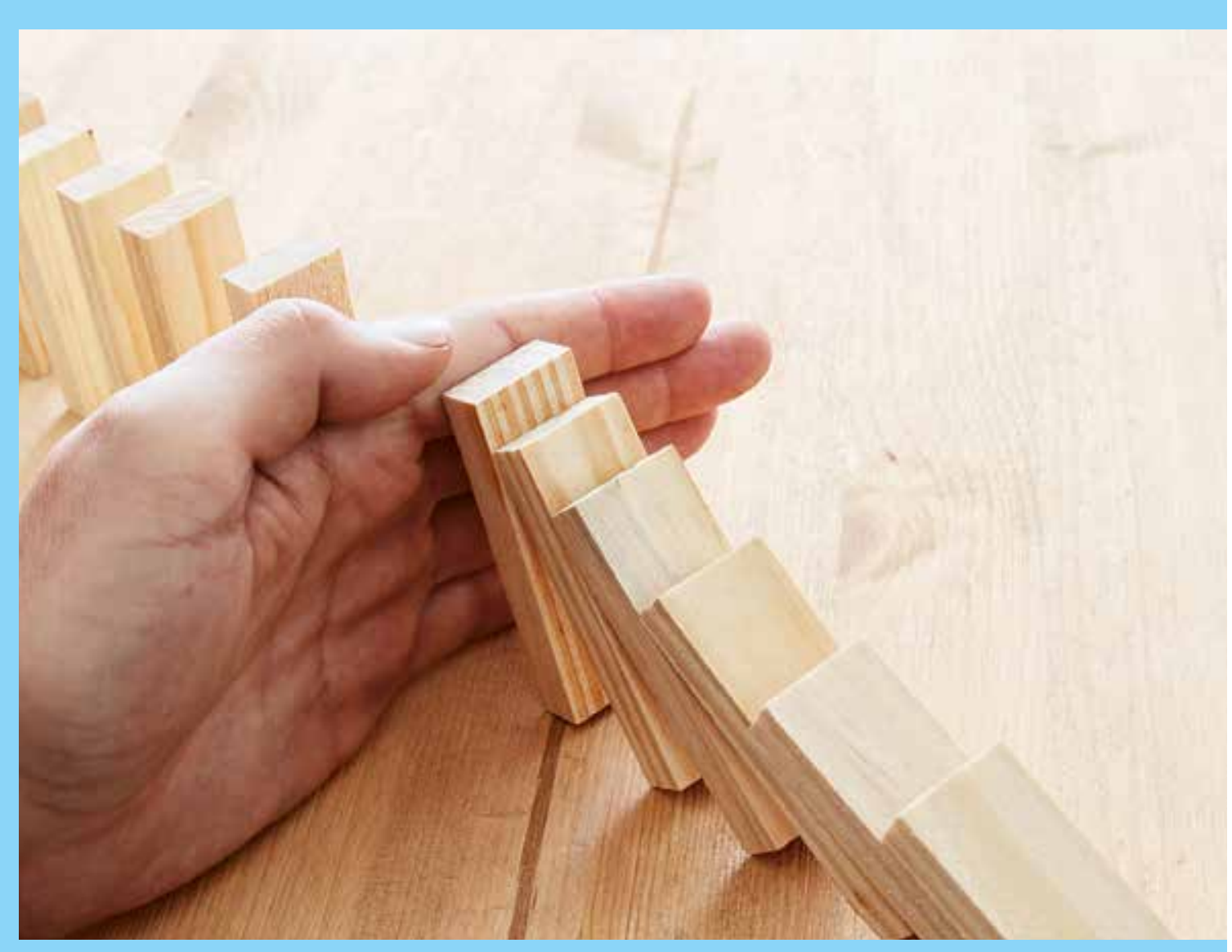

\section{Inleiding}

De samenwerking van docenten in professionele leergemeenschappen ( $\left.P L G^{\prime} s\right)$ is gericht op hun professionele ontwikkeling en het verbeteren van de prestaties van hun leerlingen. Samenwerking tussen docenten van verschillende scholen biedt een nog grotere variatie aan middelen en expertise. Met Pilots voor de ontwikkeling van professionele leergemeenschappen heeft het Ministerie van Onderwijs, Cultuur en Wetenschap het samenwerken van docenten in bovenschoolse PLG's gestimuleerd. Dit rapport was om precies te zijn gericht op een groep docenten van verschillende scholen voor voortgezet onderwijs die, begeleid door een externe coach, samenwerken om hun vakspecifieke onderwijs te verbeteren of een probleem gerelateerd aan hun lesgeven op te lossen.'

De 23 eerste PLG's in dit kader, met gemiddeld tien deelnemers per bijeenkomst, afkomstig uit elf verschillende regio's, zijn gestart in 2013 en 2014 voor een periode van 1 tot 4 jaar. Zij werden gefaciliteerd door een externe begeleider van een universitaire lerarenopleiding, meestal in combinatie met een begeleider van een opleiding voor leraren voortgezet onderwijs van een hogeschool. Elke PLG kon aan een eigen doel werken, bijvoorbeeld: het ontwikkelen van differentiatievaardigheden en -materiaal bij Engels, het versterken van de kritisch-reflectieve houding van docenten of het ontwikkelen van nieuw lesmateriaal voor aardrijkskunde. De deelnemers kwamen om de 4 à 6 weken bij elkaar.

De Universiteit Twente heeft n.a.v. dit project landelijk onderzoek gedaan, waarbij onderzocht werd wat de effecten van het deelnemen aan de PLG's waren op de professionele ontwikkeling van de deelnemende docenten (tevens van de hierboven beschreven PLG's). Bovendien is onderzocht welke factoren van invloed zijn op professionele ontwikkeling én is er ook nog aanvullend onderzoek verricht naar duurzaamheid, omdat een aantal PLG's hun activiteiten wilden voortzetten.

\section{Onderzoeksopzet naar factoren, effecten en duurzaamheid}

We hebben ten eerste de tevredenheid, kennisontwikkeling, vaardigheden en professionele houding, en de toepassing van het geleerde door deelname aan de PLG's onderzocht (Prenger, Poortman \& Handelzalts 2018). Wat betreft beïnvloedende factoren hebben we gekeken in welke mate en op welke manier factoren die volgens de literatuur relevant zijn van invloed waren (Prenger, Poortman \& Handelzalts 2017). Het ging daarbij om zowel individuele factoren, zoals motivatie, als teamfactoren, zoals samenwerking.

Voor dit onderzoek is gebruikgemaakt van een jaarlijks aan alle deelnemende docenten rondgestuurde vragenlijst en van een logboek (per bijeenkomst) voor alle PLG-begeleiders, in combinatie met kwalitatief casestudieonderzoek bij vijf PLG's. Voor de casestudies hebben we interviews gehouden met docenten en PLG-begeleiders, en bijeenkomsten geobserveerd.

Voor het onderzoek naar duurzaamheid hebben we gekeken naar de manier waarop

6. De eerder beschreven PLG's zijn meegenomen in het landelijk onderzoek door de Universiteit Twente, waarvan Cindy Poortman hier een resumé beschrijft.

7. Deze bijdrage is een samenvatting van Poortman, Prenger \& Handelzalts (2018), de eindbundel van het pilotproject voor de ontwikkeling van professionele leergemeenschappen, samengesteld en geschreven m.m.v. de begeleiders/ onderzoekers van de deelnemende PLG's. Het PLG-onderzoeksteam dankt het Ministerie van OCW voor het mogelijk maken van dit onderzoek en dankt de PLG-begeleiders/onderzoekers, docenten en hun collega's voor hun deelname an het onderzoek. 
langetermijnveranderingen zijn gerealiseerd als resultaat van de PLG's. Hiervoor hebben we na afloop van het oorspronkelijke project, binnen driekwartjaar na afronding, bij vijf PLG's interviews afgelegd met een PLG-begeleider, een PLG-docent en een schoolleider van de deelnemende docent. In deze interviews kwam een hele reeks vragen aan de orde, onder andere:

- Is de PLG nog actief?

- Wat waren de opbrengsten en in hoeverre zijn, of worden, deze (nog) toegepast op de school van de deelnemers?

- In hoeverre is de PLG-werkwijze onderdeel van de scholen geworden?

- Wat was de rol van de schoolleiding in het bevorderen van de duurzaamheid van

(de opbrengsten van) de PLG's?

\section{Effecten}

In het algemeen heerste onder de docenten vanaf de eerste meting enthousiasme en redelijke tevredenheid over hun deelname aan een PLG, zo bleek uit de antwoorden op de vragenlijsten. De docenten waren dan ook zeer gemotiveerd om eraan deel te nemen. Ze noemden het een bijzonder prettige manier van professionalisering en vonden de PLG's inspirerend en leerzaam. De opkomst was echter volgens de deelnemers niet altijd groot en de facilitering niet overal goed geregeld, waardoor zij sommige bijeenkomsten niet voldoende konden voorbereiden. De deelnemers waren in het tweede jaar gematigd positief over de mogelijkheid zich nieuwe kennis en vaardigheden eigen te maken, al hebben de meeste docenten wel concrete producten ontwikkeld als resultaat van hun PLG-deelname, op het gebied van meerdere lessen en onderzoeksinstrumenten.

Tijdens de eerste meting bleek dat vooral tussenproducten of een opzet daartoe waren ontwikkeld en, volgens de gegevens van de tweede meting, pasten sommige docenten het ontwikkelde lesmateriaal ook al toe - nog niet op grote schaal, maar wel in hun eigen klas. Het kostte namelijk betrekkelijk veel tijd en inspanning om aanpassingen op school te realiseren en men was ook nog onzeker over de kwaliteit en impact van het ontwikkelde materiaal. Het gemiddelde van de resultaten van de derde vragenlijst is op elk gebied hoger dan op de voorgaande vragenlijstmeting.

Volgens de vierde vragenlijst zijn de scores op effecten van deelname aan een PLG nagenoeg hetzelfde als in het voorgaande jaar. Deelnemers waardeerden de uitwisseling, hebben deelname aangeraden aan anderen en hebben er kennis opgedaan. Volgens hen kwamen de leerlingen steeds meer centraal te staan. Het is in dit verband een groot voordeel dat de PLG's de gelegenheid hebben gehad zich gedurende vier jaar te ontwikkelen. Uit de literatuur komt naar voren dat we de ontwikkelingsfasen kunnen onderscheiden, van 'starter', via 'ontwikkelaar' naar 'rijp', waarbij men in het begin meer gericht was op het (verder) ontwikkelen van een gezamenlijk doel en visie, en in de latere fasen meer op (hoge verwachtingen en) leerlingen (Stoll et al. 2006).

Als het gaat om de concrete resultaten van deelname aan een PLG zei bijna $70 \%$ van de docenten dat hun hun deelname heeft geleid tot nieuwe concrete lesmaterialen, gaf bijna $50 \%$ van hen aan hele lesseries te hebben ontwikkeld en rapporteerde bijna $40 \%$ dat de PLG tot een aanscherping van het praktijkonderzoek had geleid. Bijna $35 \%$ gaf aan dat zij onderzoeksinstrumenten hadden ontwikkeld/verkregen en $20 \%$ een docenthandleiding. Van de deelnemers liet $16 \%$ weten dat de PLG geresulteerd heeft in betere (leer)prestaties bij de leerlingen. Slechts $3 \%$ van de deelnemers antwoordde dat ze geen concrete producten hadden ontwikkeld of overgehouden aan hun deelname in de PLG. Daarnaast gaf $22 \%$ andere concrete opbrengsten aan, zoals het hebben verkregen van didactisch houvast om specifieke problemen aan te pakken, meer achtergrondkennis en uitwisseling van ideeën, maar ook meer inzicht in de leerlingen en het onderwijs. Ook genoemd werden een grotere betrokkenheid en vertrouwen, en het terugvinden van de passie voor het onderwijs.

\section{Factoren}

PLG-deelnemers waren gemiddeld (zeer) gemotiveerd om zich in te zetten voor hun PLG. De samenstelling van de deelnemers was volgens hen gevarieerd, bijvoorbeeld qua leeftijd, geslacht en vak, en ook of zij eerste- of tweedegraads docent waren (wat ook geldt voor de voorkennis). Deelnemers dachten in het algemeen gematigd positief over de vraag of er een gezamenlijk doel is. Een te groot verschil in achtergrond en erg veel deelnemers kunnen het gevoel van een gezamenlijk doel in de weg staan.

Veel docenten gaven aan dat de motivatie om mee te doen deels samenhing met het bovenschoolse aspect en de mogelijkheid om kennis tussen scholen uit te wisselen. Docenten kwamen om kennis te vergaren. Ze wilden meer met hun vak bezig zijn en meer bijdragen aan de ontwikkeling van het onderwijs.

Wat betreft de reflectieve dialoog geldt dat de respondenten gematigd positief reageerden op stellingen als 'In deze PLG reflecteren we op relevante onderwerpen'. Enkele docenten (met hoge voorkennis) misten verdieping, wat bevestigd wordt door meerdere PLG-begeleiders. Over het algemeen was het vertrouwen goed binnen de PLG's; er was sprake van een goede, open, respectvolle sfeer.

Ook over samenwerking en actieve deelname waren de respondenten gematigd positief. Enkele docenten rapporteerden dat er ervaringen werden uitgewisseld, geluisterd werd op elkaars inzichten werd voortgebouwd en dat er reflectieve vragen werden gesteld.

De respondenten waren zeer positief over de PLG-begeleiders. Ze beoordeelden de begeleiding over het algemeen als enthousiast, kundig en doelgericht. Er is ook gevraagd naar gedeeld leiderschap, zoals uitgevoerd door de deelnemende docenten. De respondenten antwoordden gemiddeld met 'eens' op stellingen als 'De leidende rol van deze deelnemers draagt bij aan de resultaten van de PLG'. Wat betreft gestructureerde, begeleide activiteiten waren de deelnemers positief. De activiteiten bestonden voornamelijk uit werken in subgroepen aan producten, bespreken van de voortgang van die producten en de toepassing ervan in de praktijk, luisteren naar gastsprekers, observeren en bezoeken van collega's op andere scholen, en het opstellen van een planning. Docenten in PLG's gaven aan dat er gestructureerd werd voortgebouwd op de activiteiten die ontplooid waren in het voorgaande jaar.

\section{Ondersteuning vanuit de school en andere betrokkenen}

Deze ondersteuning werd als gematigd positief ervaren. Hoewel docenten gemiddeld bijna 11 uur per maand besteedden aan hun PLG in het vierde jaar, kregen zij gemiddeld maa 6,5 uur per maand gefaciliteerd om de PLG bij te wonen. Uit de logs en interviews blijkt dat ondersteuning vanuit de schoolleiders minimaal was. Veel docenten geven aan dat ze geen contact met de schoolleider hebben gehad en, als dat wel het geval is, zij dan vaak zelf het initiatief hebben genomen.

PLG-begeleiders bevestigden dat de interesse vanuit de schoolleiding minimaal was. Eenmaal thuis werd verder gewerkt aan het voorbereiden van de volgende bijeenkomst, bijvoorbeeld 
in de vorm van inlezen, werken aan het product en doel dat men zich voor ogen heeft gesteld en het voorbereiden van een presentatie. Ook werd in de periode tussen bijeenkomsten de planning met de schoolleiding besproken en bezoeken van de vakdidactisch begeleider gedaan en elkaars werk gelezen. Docenten vonden het logisch om er thuis verder aan te werken, maar konden hiervoor niet altijd de tijd vinden. Daarentegen werd het contact met collega's over de PLG in de loop van het project wel steeds groter. Sommige deelnemers vroegen collega's om feedback te geven op producten, deelden producten met collega's, of hadden veel contact met de collega van de eigen school die ook deelnam aan de PLG. Sommigen brachten informatie over de PLG in op de vakgroepvergaderingen in. Veel docenten gaven aan dat het helpt de opgedane kennis en informatie samen met een collega terug te koppelen naar de school.

\section{Duurzaamheid}

Volgens de laatste vragenlijstmeting deelde ruim $71 \%$ van de respondenten kennis vanuit de PLG in informele gesprekken met collega's, gaf $38 \%$ aan dat zij dat in teamvergaderingen doet deelde $29 \%$ kennis door het geven van presentaties, had $15 \%$ workshops over het onderwerp van de PLG gegeven en $14 \%$ kennis gedeeld via de nieuwsbrief van de school. Bovendien gaf $26 \%$ van de respondenten aan dat zij kennis op andere manieren deelden, zoals door midde van een werkgroep in de eigen school, het starten van eigen PLG-teams, sectieoverleg, ouderbijeenkomsten, interviews en het laten uitvoeren van zelf ontworpen lessen (series) door collega's. Deze bevindingen laten zien dat in de latere fase schoolbreed gebruik is gemaakt van de PLG-werkwijze en/of uitkomsten.

Uit de interviews komt naar voren dat deelnemers aan vier van de vijf PLG's daarin nog actief zijn (ten tijde van de interviews), hoewel sommigen wat minder bijeenkomsten volgden dan voorheen. De deelnemers aan de vijfde PLG maken plannen voor voortzetting. In alle PLG's zijn producten ontwikkeld die in de praktijk van de deelnemende docenten worden toegepast (zoals practica of online-lessen in het kader van flipping the classroom).

De in de PLG ontwikkelde kennis wordt op uiteenlopende manieren gedeeld binnen de scholen van de geïnterviewde deelnemers. Dit varieert van regelmatig, formeel en informeel, binnen en buiten de eigen sectie, tot vrijwel geen kennisdeling met anderen binnen de school, alleen in de eigen sectie en alleen informeel. Het gaat daarbij meer om lesmateriaal of lesvormen dan om het proces en werkwijze van de PLG om bijv. een PLG in de eigen school als spin-off te realiseren, hoewel ook dat laatste voorkomt.

Overigens zijn niet alle respondenten van mening dat kennisdeling en verspreiding binnen de school van belang zijn. Uit bijna alle interviews werd duidelijk dat men vindt dat de rol van de schoolleider hierin (sterk) voor verbetering vatbaar is. Schoolleiders zijn (hooguit) op de hoogte van de activiteiten in de PLG, maar tonen hiervoor geen speciale interesse, of de schoolleider ziet de PLG-deelname van de docent als individuele professionalisering en niet als een manier om de PLG-werkwijze en -opbrengsten te implementeren in het onderwijs op school. Zelfs als het alleen om facilitering van deelname ging, lukte dat niet altijd of was het zelfs belemmerend, bijvoorbeeld omdat een deelnemer gevraagd was op school aanwezig te zijn, terwijl er een PLG-bijeenkomst was.

Wel kwam het enkele malen voor dat deelnemers presentaties en workshops verzorgden aan collega's en als aanspreekpunt dienden voor collega's op het thema van de PLG. Ook zijn kennis en andere opbrengsten die gericht zijn op een vak buiten de school gedeeld en verspreid, en is een PLG-begeleider vanwege ontwikkelde expertise door andere scholen benaderd om daar ook PLG's over dit thema op te zetten.

\section{Conclusies}

Hoewel de deelnemers aan PLG's er redelijk tevreden over zijn, d.w.z. een betere houding, grotere kennis en vaardigheden hebben ontwikkeld en steeds meer op het leren van leerlingen gericht zijn, zien we dat PLG's ook in het laatste jaar nog voor verbetering vatbaar zijn. We kunnen dit mogelijk verklaren uit de bevindingen wat betreft de beïnvloedende factoren. Het gaat dan bijvoorbeeld om verschillen in achtergrond (en voorkennis) van de deelnemers en wisselingen in de facilitering. Dit kan ook hebben doorgewerkt in de bevindingen wat betreft duurzaamheid. We zien dat bijna alle respondenten van de PLG's (van de casestudie) nog actief zijn, en het is de bedoeling dat de andere respondenten ook verdergaan. Wat betreft kennisdeling binnen de school zien we grote onderlinge verschillen. In de literatuur wordt beweerd dat PLG's veelbelovend zijn - niet alleen voor de individuele professionele ontwikkeling van docenten, maar ook voor continue schoolverbetering en uiteindelijk verbetering van het hele onderwijssysteem (Poortman \& Brown 2018). Hoewel dit nog een uitdaging is, zijn er al verschillende voorbeelden aan te wijzen van het delen van PLGuitkomsten en -werkwijzen, zowel binnen de scholen als daarbuiten.

\section{Aanbevelingen voor praktijk en beleid}

In de praktijk blijkt dat de bevindingen van PLG's zeer nuttig kunnen zijn voor professionele ontwikkeling. De meeste docenten nemen er met veel plezier aan deel, waar zij van leren en met behulp waarvan zij het geleerde kunnen toepassen in hun praktijk. Gezien de verscheidenheid aan onderwerpen en aanpak was het effect ervan op de leerresultaten van leerlingen geen onderwerp van dit onderzoek. Sommige docenten benoemden in de interviews wel het resultaat op leerlingniveau, maar hiernaar werd geen systematisch onderzoek verricht. Het is wetenschappelijk gezien een grote uitdaging om het effect van docentprofessionalisering op leerresultaten van leerlingen aannemelijk te maken (Poortman \& Schildkamp 2016); bovendien zijn PLG's pas in een latere ontwikkelingsfase meer gericht op het resultaat dat ze opleveren voor leerlingen (Stoll et al. 2006).

Tegelijkertijd zien we uitdagingen als het gaat om facilitering en het delen van de uitkomsten met collega's. Als er meer bekend zou zijn over positieve resultaten op toepassings- en leerlingniveau, zouden scholen misschien overtuigder zijn van het belang van facilitering en kennisdeling. Uit de literatuur (Hubers \& Poortman 2017) blijkt dat al vóór het opstarten van PLG's rekening gehouden moet worden met factoren als een gedeeld doel - niet alleen voor de PLG maar ook voor de hierbij betrokken scholen -, leiderschap (en facilitering) en kennisdeling binnen de scholen van de deelnemers, om duurzaamheid te bevorderen.

Beleidsmakers zijn steeds meer geïnteresseerd in het stimuleren van professionele ontwikkeling van docenten in netwerken, ook met het oog op continue schoolverbetering en uiteindelijk verbetering van het gehele onderwijssysteem (Poortman \& Brown 2018). Met project werd de kans geboden om dit ruim vier jaar lang te onderzoeken. Hieruit is gebleken dat de PLG's inderdaad steeds meer gericht zijn op toepasbare producten en op hun focus hebben op leerlingen. Hoewel veel docenten na afloop van een PLG meer plezier aan hun werk beleefden, hadden veel van dit soort bijeenkomsten regelmatig te kampen met een slechte opkomst, groot verloop en zelfs staken van deelname onder de docenten als gevolg van een gebrek aan een langetermijnvisie en/of facilitering op hun scholen. 


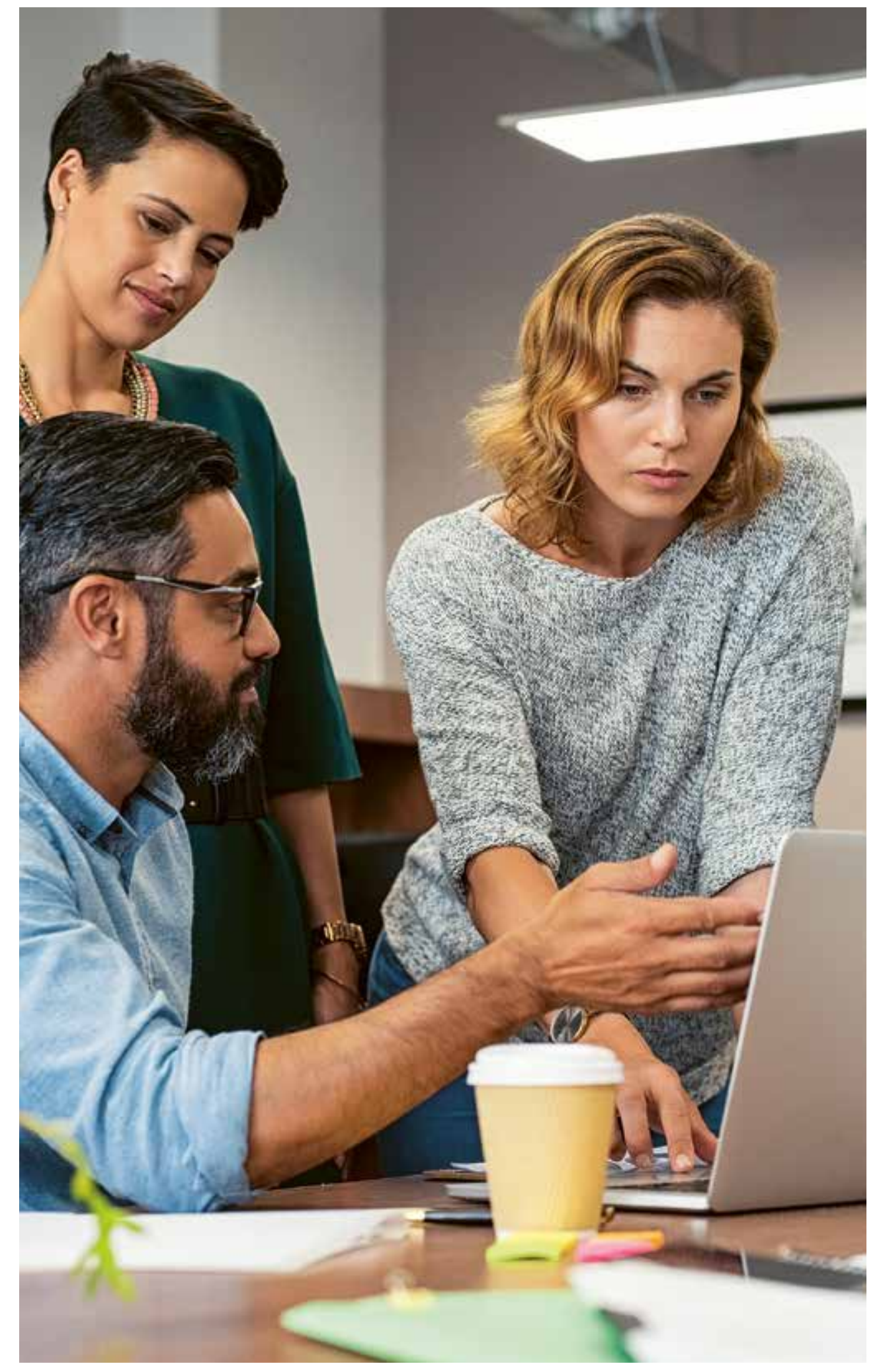

Het onderzoek van Prenger et al. heeft laten zien dat op scholen niet altijd voldoende tijd en gelegenheid, of interesse van collega's, aanwezig is om nieuwe inzichten uit te proberen in de klas. Uit ander onderzoek blijkt dat docenten, ook als zij positief tegenover veranderingen en interventies staan, een spanningsveld ervaren tussen experimenteren en het (examen) programma (McKenney \& Poortman 2017). Als we van docenten verwachten dat zij het onderwijs verbeteren en hiervoor onderzoek doen en experimenteren, is het belangrijk dat zij niet alleen ruimte en gelegenheid ervaren om deel te nemen aan bijeenkomsten van een PLG, maar ook om - in samenwerking met collega's - op hun school te experimenteren met de bevindingen die ze daarin hebben opgedaan. Dat laatste is minstens zo belangrijk.

\section{Referenties}

Brown, C., \& Poortman, C.L. (2018). Networks for learning: effective collaboration for teachers, school and system improvement. London: Routledge.

Poortman, C. L., \& Schildkamp, K. (2016) Solving student achievement problems with a data use intervention for teachers. Teaching and teacher education, 60, 425-433.

Prenger, R., Poortman, C. L., \& Handelzalts, A. (2020). Professional learning networks: From teacher learning to school improvement? Journal of educational change. https://doi.org/10.1007/s10833-020-09383-2

Prenger, R., Poortman, C. L., \& Handelzalts, A. (2018). The Effects of Networked Professional Learning Communities. Journal of Teacher Education. https://doi.org/10.1177/0022487117753574

Prenger, R., Poortman, C. L., \& Handelzalts, A. (2017). Factors influencing teachers' professional development in networked professional learning communities. Teaching and teacher Education, 68, 77-90.

De Vries, S., Prenger, R., \& Poortman, C. (2017). A lesson study professional learning network in secondary education. In Networks for learning: effective collaboration for teachers, school and system improvement (pp. 135-151). London: Routledge.

Hubers. M.D., \& Poortman, C.L. (2017). Establishing sustainable school improvement through Professional Learning Networks. In Networks for learning: effective collaboration for teachers, school and system improvement (pp. 194-204). London: Routledge.

McKenney, S., \& Poortman, C.L. (2017). Docenttoerusting voor betekenisvol vmbo. Eindrapportage preproject TechYourFuture.

Poortman, C. L., Prenger, R., \& Handelzalts, A. (2017). Vergroot je repertoire met PLG. Didaktief, 47(9), 40-42.

Stoll, L., Bolam, R., McMahon, A., Wallace, M., \& Thomas, S. (2006). Professional learning communities: A review of the literature. Journal of educational change, 7(4), 221-258. 
Tijdens het project vormden de PLG-facilitators ook een eigen PLG. Daarin bespraken ze de 'bloed zweet en tranen' en dus wat wel en niet werkte. De PLG-projectbesprekingen geven ook inzicht in hoe dergelijke professionaliseringstrajecten te faciliteren zijn. Voor deze

besprekingen hebben de facilitators data verzameld en bijgehouden door ze in te spreken in het zgn. 'bloed, zweet en tranen'-audiologboek. Deze audio-reflecties vormden input voor de besprekingen.
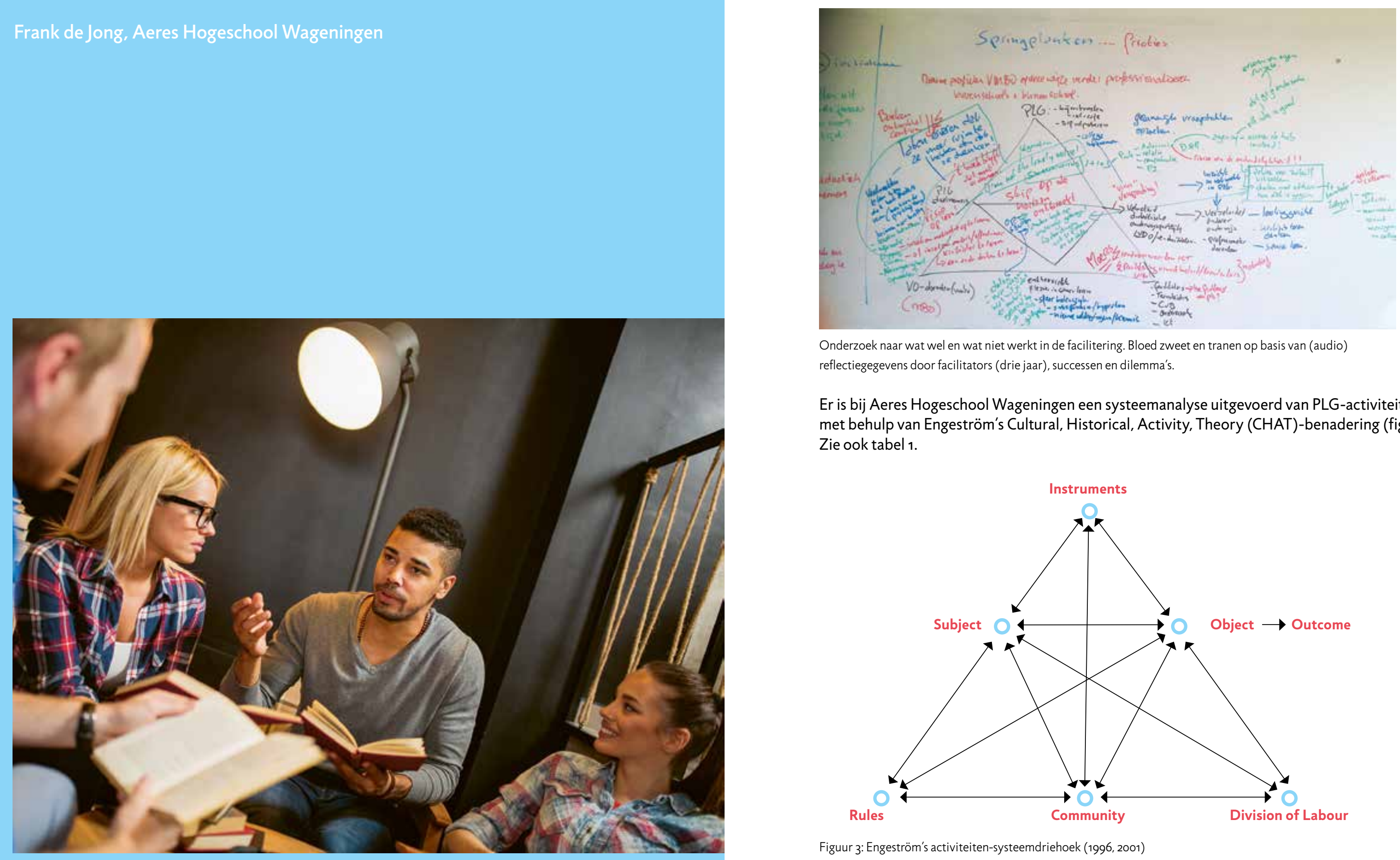

Onderzoek naar wat wel en wat niet werkt in de facilitering. Bloed zweet en tranen op basis van (audio) reflectiegegevens door facilitators (drie jaar), successen en dilemma's.

Er is bij Aeres Hogeschool Wageningen een systeemanalyse uitgevoerd van PLG-activiteiten met behulp van Engeström's Cultural, Historical, Activity, Theory (CHAT)-benadering (fig. 3). Zie ook tabel 1.

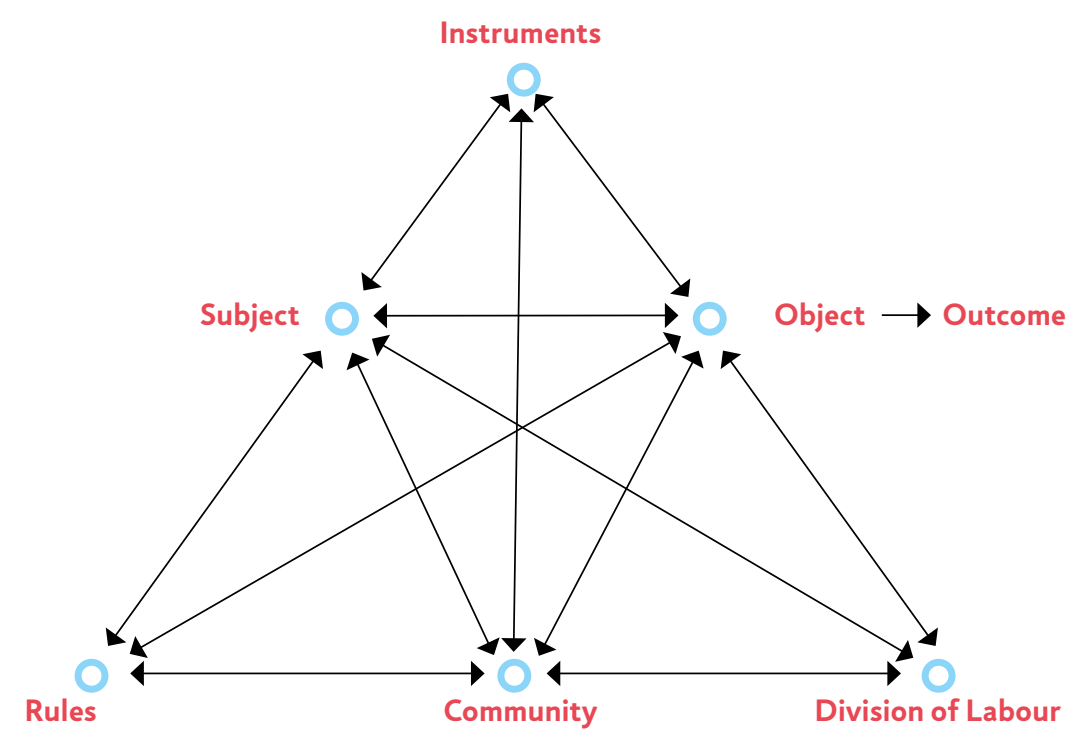

Figuur 3: Engeström's activiteiten-systeemdriehoek $(1996,2001)$ 
Tabel 1: Activiteitenanalyse en naar voren komende dilemma's

\begin{tabular}{|c|c|c|c|c|}
\hline & & Intentie/facilitator & Werkt positief & $\begin{array}{l}\text { Fricties, dilemma's die } \\
\text { kunnen opspelen in het } \\
\text { PLG-activiteittensysteem }\end{array}$ \\
\hline Subject & Deelnemer(s) & $\begin{array}{l}\text { - Laten ervaren dat ze meer } \\
\text { ruimte hebben dan ze } \\
\text { denken } \\
\text { - Voortbouwen op be- } \\
\text { staande praktijk en laten } \\
\text { zien dat het anders kan }\end{array}$ & $\begin{array}{l}\text { - Locaties bezoeken } \\
\text { Informatie flipping the } \\
\text { classroom } \\
\text { - Nieuwsgierigheid } \\
\text { opwekken } \\
\text { - 'I'm not the lonely wolve' } \\
\text { (lotgenoten vinden) } \\
\text { - Samen ervaringen } \\
\text { opdoen (1+1=3) } \\
\text { - PINK (autonomie, } \\
\text { relatie, competentie, } \\
\text { professionele identiteit) }\end{array}$ & $\begin{array}{l}\text { - "t Boek blijft dat moet er } \\
\text { doorheen" } \\
\text { - Visie op leren (gebrek } \\
\text { aan) } \\
\text { - Inzet om motivatie te } \\
\text { verhogen, of } \\
\text { - Inzet om anders, effec- } \\
\text { tiever, kritisch te leren } \\
\text { - Een andere vorm van } \\
\text { denken aanleren }\end{array}$ \\
\hline Tool & PLG & $\begin{array}{l}\text { - Bijeenkomsten } \\
\text { organiseren } \\
\text { - ICT-café } \\
\text {-Zelfuitproberen } \\
\text { - Collegás meenemen } \\
\text { - Gezamenlijke vraagstuk- } \\
\text { ken opzoeken }\end{array}$ & & \\
\hline Doel & $\begin{array}{l}\text { Verbeterde } \\
\text { didactischeonder- } \\
\text { wijspraktijk door } \\
\text { LVDO/e-middelen }\end{array}$ & $\begin{array}{l}\text { Inzicht in wat werkt in } \\
\text { de PLG }\end{array}$ & 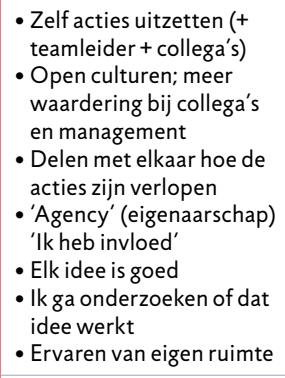 & $\begin{array}{l}\text { - Virusverspreiding } \\
\text { - } \text { Risico van de ondui- } \\
\text { delijkheid (het is seen } \\
\text { cursus?! Aha!) } \\
\text { - Biju juitzetten acties } \\
\text { geconfronteerd worden } \\
\text { met gesloten culturen }\end{array}$ \\
\hline Output & $\begin{array}{l}\text { - Professionelere } \\
\text { docenten }\end{array}$ & $\begin{array}{l}\text { - Leerlinggericht } \\
\text { - Kritischer leren denken } \\
\text { - Samen leren }\end{array}$ & & \\
\hline Taakverdeling & $\begin{array}{l}\text { Facilitators } \\
\text { Teamleiders } \\
\text { CvB } \\
\text { Onderzoekers } \\
\text { ICT }\end{array}$ & & & $\begin{array}{l}\text { - Moeras } \\
\text { - Randvoorwaarden ict } \\
\text { - Facilitering vanuit beleid } \\
\text { - Facilitering door } \\
\text { teamleiders }\end{array}$ \\
\hline $\begin{array}{l}\text { Cultuur } \\
\text { community }\end{array}$ & $\begin{array}{l}\text { Enthousiast, plezier } \\
\text { in samen leren }\end{array}$ & $\begin{array}{l}\text { - Sfeer belangrijk } \\
\text { - Ontspannen bijpraten en } \\
\text { ideeën uitwisselen } \\
\text { - Nieuwe uitdagingen en } \\
\text { kennis organiseren }\end{array}$ & $\begin{array}{l}\text { - Delen } \\
\text { - Vragen: wat wil je dat } \\
\text { er anders gebeurt bij je } \\
\text { leerlingen? } \\
\text { - Gastsprekers }\end{array}$ & \\
\hline Regels & $\begin{array}{l}\text { VO-docenten als } \\
\text { deelnemer }\end{array}$ & & - & $\begin{array}{l}\text { Mbo- en hbo docenten } \\
\text { dan? }\end{array}$ \\
\hline Algemeen & & $\begin{array}{l}\text { Uitwisseling ervaringen: } \\
\text { hoe doe jii dat en wat } \\
\text { werkt? }\end{array}$ & $\begin{array}{l}\text { Andere kijk op onderwijs } \\
\text { gekregen door dingen uit } \\
\text { te proberen }\end{array}$ & $\begin{array}{l}\text { Stip op de horizon } \\
\text { ontbreekt }\end{array}$ \\
\hline Uitdagingen & & $\begin{array}{l}\text { - Nieuwe profielen VMBO } \\
\text { op deze wijze verder } \\
\text { professionaliseren, zowel } \\
\text { boven- als binnenschools } \\
\text { - Train de deelnemer als } \\
\text { facilitator } \\
\text { - PLG uitbreiden naar mbo, } \\
\text { hbo, management }\end{array}$ & $\begin{array}{l}\text { - Stip op de horizon } \\
\text { - Omgaaan met de } \\
\text { 'onduidelijkheid van niet } \\
\text { streven naar' 'kennis/ } \\
\text { informatie' overdragen, } \\
\text { maar mensen verleiden } \\
\text { hun ideeenn uit te pro- } \\
\text { beren in hun praktikijen } \\
\text { verder te ontwikkelen. }\end{array}$ & \\
\hline
\end{tabular}

\section{Wat werkt nog meer:}

- Proces: bewuster inzetten/sturen op autonomie van deelnemers.

- Koppeling PLG-thema aan en visie op leren; Visie op leren (LVDO) $\rightarrow$ expliciet leren + verbinden met ruimte.

- Veranderproces (weerstand) als thema neerzetten.

- Dialoog op gang brengen, de opbrengsten vastleggen/vasthouden.

- De juiste vragen op de juiste manier stellen.

Relaties versterken/verbinden.

- Vertrouwen laten groeien in $\mathrm{t}$ veranderen.

- Mensen laten kiezen.

- Inspireren/nieuw/ruimte geven in de hoop dat de nieuwe mensen snel mee kunnen.

- Ruimte $\rightarrow$ autonomie $\rightarrow$ implementatie kansen.

\section{Referenties}

Engeström, Y., Virkkunen, J., Helle, M., Pihlaja, J., \& Poikela, R. (1996). The Change Laboratory as a Tool for Transforming Work. Lifelong Learning in Europe, 1(2), 10-17.

Hays, J. M. (2007). Dynamics of Organisational Wisdom. Business Renaissance Quarterly, 2(4) $77-112$. 


\section{Hoofdstuk 7 \\ Suggesties voor succesvolle PLG's op basis van ervaring}

Frank de Jong, Aeres Hogeschool Wageningen

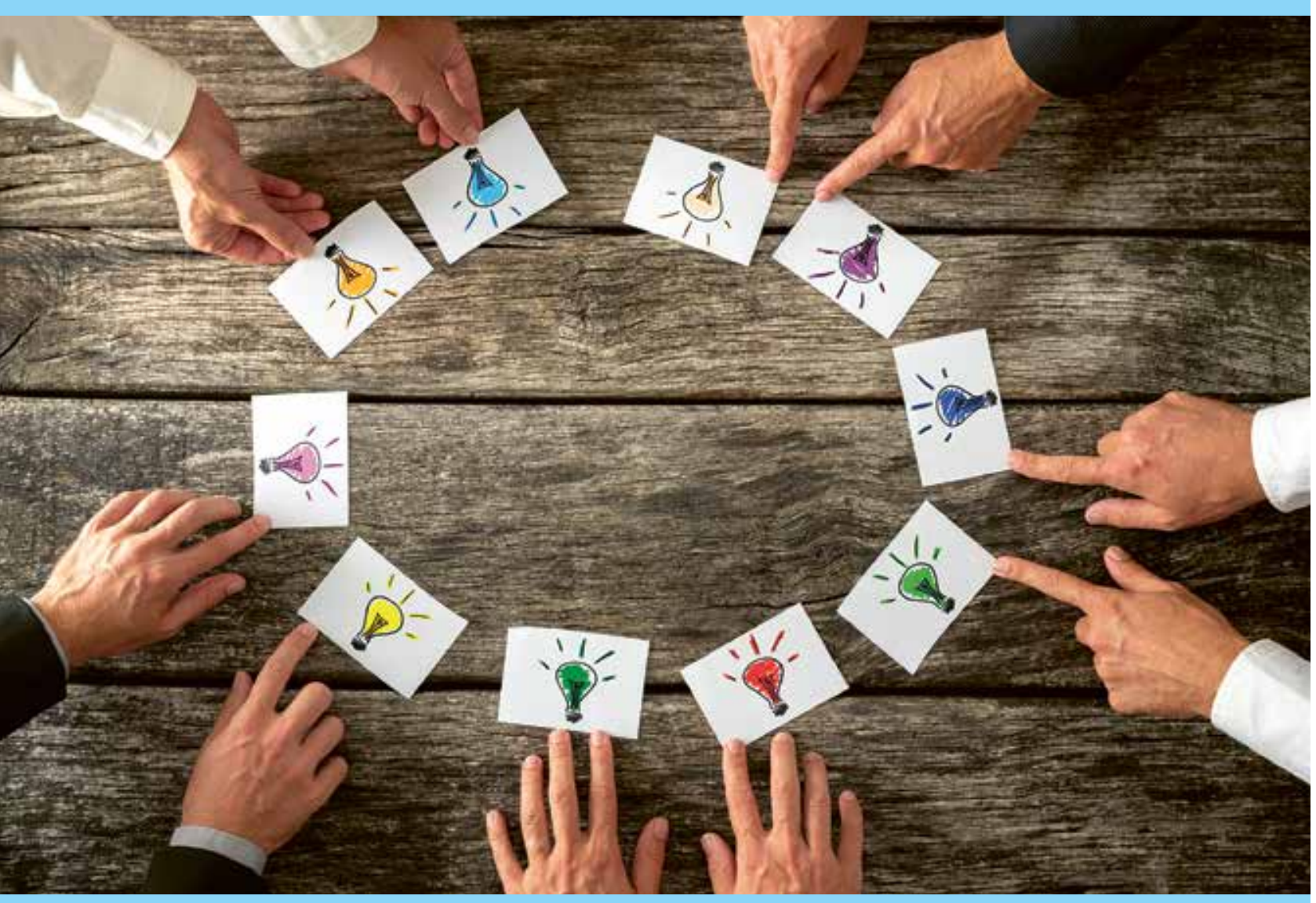

66
Aan het project hebben uiteenlopende PLG-groepen meegedaan. Eerst werd bovenschools gewerkt, wat wil zeggen dat docenten van verschillende locaties en van verschillende onderwijsorganisaties in een PLG zaten. Projectleiders, facilitators en deelnemers merkten dat een PLG-groep van ongeveer veertien docenten van zeven verschillende locaties goed werkt.

Als redenen daarvoor gaven de docenten zelf aan: "Het is goed om met een collega te komen. Je hebt het erover op de heen- en terugweg. Op de locatie is het handig om elkaar tussendoor even aan te schieten. Zo houd je het makkelijker levend in de hectiek van alle dag." In de praktijk bleek een PLG met docenten van meerdere locaties binnen één onderwijsorganisatie het meest soepel en meest effectief te werken. Dat kwam ook door meer betrokkenheid vanuit het management en derhalve een goede ondersteuning. Het verduurzamen werd daarmee ook gemakkelijker te realiseren. De parallelle belangen, het beleid binnen eenzelfde schoolorganisatie en de kortere lijnen binnen één $\mathrm{AOC}$ met meerdere vmbo-vestigingen hielpen daarbij.

Ook bleek dat het onderscheid tussen vak- en avo-docenten niet noemenswaardig heeft bijgedragen aan separate 'vak-PLG's'. Vak- en Avo-docenten vonden het juist leuk om met elkaar in één PLG te werken en te leren. De heterogeniteit van de deelnemers maakte de PLG juist boeiend. Een open uitwisseling, laten zien wat er ontwikkeld is en hoe het werkt, met en voor leerlingen (of soms ook niet), vormen een belangrijke basis van een PLG - een basis om met elkaar te proberen te doorgronden waarom het ene wel en het andere minder werkt.

Elkaar bevragen op het ontwikkelde materiaal, wat je beoogde, hoe je het wilde uitvoeren en hoe het uiteindelijk ging in de praktijk. Elkaar suggesties geven om ontwikkelde toepassingen mogelijk nog effectiever te maken. Dat alles maakte de PLG's tot echte leergemeenschappen. De plek waar je wilt zijn, waar je als docenten kunt samenwerken aan en denken over professionele identiteit, didactische werkvormen, oefenen in kritiek, feedback geven en ontvangen.

Het maakte en maakt de PLG's ook tot de plek waar het gesprek ontstaat en gaande kan blijven over hoe het een deelnemer verwoorde: "hoe we elkaars opgedane kennis en ervaring kunnen delen op de locaties en wat we nodig hebben om eigen, misschien kleine, PLG's te helpen ontstaan en te faciliteren."

Uit de bijdragen in dit boekje zijn heel wat ervaringen naar voren gekomen. Die ervaringen zal ik in deze bijdrage op een rijtje proberen te zetten. Het zestal vragen ofwel 'ontwerpankerpunten' waar de bijdrage van Harm Schaap (hoofdstuk 2) in uitmondt, gebruik ik voor het ordenen van die ervaringen. Elk van de PLG-casussen (hoofdstuk 3 ) eindigt met 'succesfactoren bij het faciliteren van een PLG'. De zes vragen zijn dus gebruikt om de ervaringen van de PLG-casussen en het onderzoek te categoriseren. Het resultaat kun je hieronder lezen. De context van de ankerpunten, ervaringen en suggesties worden mogelijk duidelijker bij het lezen van de casusbeschrijvingen. Indien overwogen wordt de kracht van een PLG voor de eigen organisatie in te zetten, dan kan met deze adviezen voordeel worden gedaan.

1. Verwachtingen, motieven en beelden van PLG-deelnemers en schoolleiders over deelname aan een PLG helder maken

- In samenspraak tussen facilitator en de praktijk helder maken wat de vraag, het doel en de beoogde opbrengsten van de PLG zullen zijn. Dit zogenaamde 'articuleren van de vraag' is een co-creatieproces van facilitators, opdrachtgever en betrokkenen docenten. Nog productiever is het om ook studenten vanaf het begin daarover te laten meedenken. 
- Aan het begin is het voor iedereen duidelijk dat met de PLG uiteindelijk een betere ondersteuning voor een succesvoller leren van de leerlingen beoogd wordt.

- Een deelnemer kiest voor een PLG op grond van informatie over wat deze is en wat ermee wordt beoogd, en conformeert zich aan de inspanningen die dat van hem zal vragen. Voor iedereen is duidelijk dat er bewust gestreefd wordt naar gedeelde resultaten.

- Het is belangrijk om elke deelnemer dingen te laten doen die dichtbij ze staan, waar ze goed in zijn of zich goed bij voelen, waar hun energie van gaat stromen en te laten doen waar hijzelf en de organisatie beter van worden.

- Geef weinig aandacht aan problemen (vaak proces) en juist veel ruimte voor energie (inhoudelijke vernieuwing). Zet de inhoud centraal, niet de problemen (zoals gebrekkig samenwerken, team-'zeer' enz.).

- Stel een deelnemersprofiel op waaruit voor de PLG-deelnemers duidelijk wordt wat er van hen verwacht wordt.

2. Borgen van deelname aan de PLG vanuit de school

- Zorg dat er voldoende budget, capaciteit, tijd en ruimte is voor deelnemende docenten, management en facilitators om het beoogde doel te realiseren. Vergeet daarbij niet om ook de tijd tussen de bijeenkomsten in te plannen en te budgetteren.

- De organisatie (MT, directie) is onderdeel van het collectief leren. Het management spreekt zich daarover uit en informeert naar de voortgang. Daarom is het van belang dat het management vanuit de PLG steeds wordt geïnformeerd en er continue mee wordt gecommuniceerd. Twee-weg communicatie dus, omdat anderzijds ook het management zich moet informeren en communiceren over de PLG!

- Deelnemers en de organisaties conformeren zich aan de PLG en geven er prioriteit aan Het management oefent dus geen druk uit om PLG-bijeenkomsten over te slaan voor andere werkzaamheden.

- Verbreding en draagvlak bij het managementteam zijn belangrijk. Geen vrijblijvende afspraken dus!

3. De rol van de schoolleiding bij een PLG gedurende het gehele schooljaar of meerdere schooljaren.

- Het management voelt zich verantwoordelijk (PLG als onderdeel van een langer

traject) en is faciliterend (wat bijvoorbeeld wil zeggen dat tussen de PLG-

bijeenkomsten ruimte en tijd wordt gereserveerd voor afstemming, voorbereiding en uitvoering in groepjes).

- Een PLG dient bottom-up gedragen te worden en niet alleen een 'top-down gebeuren van het management te zijn.

- Het team en de teamleider dienen beschikbaar voor elkaar te zijn, d.w.z. open te staan voor vragen en hulp.

- Zorg voor nazorg vanuit het voorbereidingstraject, oftewel begeleiding bij de implementatie en of continuering van de PLG, zodat het geleerde niet wegvalt na afloop van een PLG-traject.

- Breng de uitgangspunten, motivatie en capaciteit van de organisatie en mensen in beeld en benut deze (Poiesz 1999).
4. Bijdragen aan professionele ontwikkeling van leraren en schoolontwikkeling

- Aansluiten bij waar de urgentie van de praktijk en waar deze staat. Docenten uitdagen in hun 'zone van nabije ontwikkeling' te stappen door met hen hun (gewenste) horizon te schetsen; te confronteren met discrepanties tussen gewenste en huidige praktijk en redenen ontdekken waarom die er zijn door dilemma's bloot te leggen waarom men niet doet wat men graag zou willen doen. Collectiviteit creëren in visie en durf om veranderingen door te voeren.

- Voor implementatie van de PLG-opbrengsten is het belangrijk om de gedeelde resultaten vast te leggen, waarbij de relatie met de visie zichtbaar is. Zo kunnen ook mensen die nieuw aanschuiven snel en vanuit collectief gedragen opvattingen meedenken en aan de slag gaan.

- Ook belangrijk voor de PLG-implementatie is het organiseren van terugkommomenten om te evalueren en te reflecteren.

- Een PLG levert met name opbrengsten op voor de deelnemers. Een van de leerdoelen is het implementeren van de opbrengsten in de organisatie.

- Maak opbrengst-gerichte afspraken, waarbij het belang van persoonlijke leren wordt overstegen om een locatiebelang te dienen.

5. Bewerkstelligen van een wisselwerking tussen feedback en reflectie als voeding voor professionalisering van leraren en schoolontwikkeling - Stel iedereen in de gelegenheid professionalisering in de PLG op eigen wijze en in eigen tempo door te voeren.

- Daarbij wel de focus leggen op samen leren/collectief leren in kleine groepjes van 3 à 4 personen ( 2 of 5 werkt niet zo goed).

- Begeleidt vanaf de zijlijn (bijsturen i.p.v. aansturen) en inspireer, bijvoorbeeld door gastsprekers uit te nodigen over thema's die de PLG-deelnemers samen aandragen.

- Stel de reflectiemomenten verdekt op; een goede gastspreker is vaak, naast inspirerend, ook confronterend ('automatische reflectie').

- Het opzetten van een PLG binnen de eigen school heeft als voordeel dat het kansen geeft om de communicatie binnen het team te versterken, doordat men elkaar op onderwerp en inhoudelijke interesse kan vinden. Zaken als het geven, vragen en ontvangen van feedback kunnen via het met elkaar werken aan inhoudelijk diepgang onderliggend aan producten en innovaties geoefend worden. Je behoeft niet altijd te benoemen als reflectie of feedback, maar het gewoon doen.

- Betrekt de studenten steeds bij de inhoud en vorm van de opleiding, liefst vanaf de opstart van een PLG.

- Erken expliciet elkaars kwaliteiten en professionaliteit.

- Het helpt als de facilitator aanwezig is om het proces te begeleiden of om achtergrondinformatie te geven, maar hij moet behalve coachend soms ook sturend/corrigerend kunnen interveniëren. 
6. Bevorderen van de leercultuur op scholen

- Een PLG geeft kansen om deelnemers in een meer actieve houding te krijgen door geleidelijk meer input van hen te vragen en deze zichtbaar en expliciet te honoreren. Bijvoorbeeld via een gastspreker, maar ook door input te vragen voor de opzet van een volgende bijeenkomst of het samen voorbereiden ervan.

- Een PLG geeft kansen om met verschillende partijen buiten het team (management leerlingen) te sparren over inhoudelijke thema's. Houd dergelijke momenten kort en krachtig, geen ellenlange discussies. Wel eindigen met conclusies en acties op korte termijn.

- Ook bij het opbouwen van een leercultuur helpt het als er een facilitator aanwezig is om dergelijke processen te begeleiden of van achtergrondinformatie te voorzien.

- Vertaal de opbrengsten bij systeeminnovaties in een meerjarenplanning.

\section{Referentie}

Poiesz, T.B.C. (1999). Gedragsmanagement. Waarom mensen zich (niet) gedragen. Wormer: Inmerc

\section{Nawoord}

Wij, Frank en Ton, de projectleiders, danken de facilitators, deelnemers, teamleiders, studenten en onderzoekers die aan de PLG's van Aeres Hogeschool Wageningen hebben meegedaan of bijgedragen. Enerzijds voor het vertrouwen dat hun investering met tijd en inzet in goede handen was om bij te dragen in hun professionele ontwikkeling en daarmee aan hun onderwijsorganisatie en niet in de laatste plaats aan de ontwikkeling van hun studenten. Anderzijds voor de leerervaringen die de PLG's ons allen hebben geboden en dat we door ieders bijdragen aan dit boekje die ervaringen met iedereen kunnen delen die het wil lezen.

Dankjullie allemaal,

Frank de Jong en Ton van Wijck 
